\title{
COMPORTAMENTO INGESTIVO DE BOVINOS EM PASTOS DE CAPIM MARANDU SUBMETIDOS A REGIMES DE LOTAÇÃO CONTÍNUA
}

\author{
DANIEL OLIVEIRA DE LUCENA SARMENTO
}

Dissertação apresentada à Escola Superior de Agricultura "Luiz de Queiroz", Universidade de São Paulo, para obtenção do título de Mestre em Agronomia, Área de Concentração: Ciência Animal e Pastagens.

P I R A C I C A B A

Estado de São Paulo - Brasil

Maio - 2003 


\title{
COMPORTAMENTO INGESTIVO DE BOVINOS EM PASTOS DE CAPIM MARANDU SUBMETIDOS A REGIMES DE LOTAÇÃO CONTÍNUA
}

\author{
DANIEL OLIVEIRA DE LUCENA SARMENTO \\ ZOOTECNISTA
}

Orientador: Prof. Dr. SILA CARNEIRO DA SILVA

\author{
Dissertação apresentada à Escola Superior de \\ Agricultura "Luiz de Queiroz", Universidade de \\ São Paulo, para obtenção do título de Mestre em \\ Agronomia, Área de Concentração: Ciência \\ Animal e Pastagens. \\ P I R A C I C A B A \\ Estado de São Paulo - Brasil \\ Maio - 2003
}




\section{Dados Internacionais de Catalogação na Publicação (CIP) DIVISÃO DE BIBLIOTECA E DOCUMENTAÇÃO - ESALQ/USP}

\section{Sarmento, Daniel Oliveira de Lucena}

Comportamento ingestivo de bovinos em pastos de capim marandu submetidos a

regimes de lotação contínua / Daniel Oliveira de Lucena Sarmento. - - Piracicaba, 2003.

$76 \mathrm{p}$.

Dissertação (mestrado) - - Escola Superior de Agricultura Luiz de Queiroz, 2003.

Bibliografia.

1. Bovinos de corte 2. Capim marandu 3. Comportamento ingestivo animal 4. Lotação contínua 5. Taxa de lotação I. Título

CDD 636.2084

"Permitida a cópia total ou parcial deste documento, desde que citada a fonte - O autor" 


\section{DEDICO}

A minha mãe Una,

pelo exemplo de vida, amor, dedicação e incentivo constante

\section{OFEREÇO}

Ao meu pai Mário Augusto,

pelo despertar da minha vocação

Aos meus irmãos Samuel e Saulo,

Pelo companherismo e incentivo 


\section{AGRADECIMENTOS}

Ao Professor Dr. Sila Carneiro da Silva, pela oportunidade, confiança, paciência, amizade e exemplo de dedicação e profissionalismo.

Ao Professor Dr. John Hodgson pelas sugestões e oportunidade de enriquecedora convivência.

Aos companheiros do Grupo de Estudos de Plantas Forrageiras (GEPF), André Sbrissia, Alexandre Gonçalves, Flávia de Andrade, Leonardo Molan e Adriano Lupinacci pelo apoio na condução do experimento.

A Todos os estagiários do Grupo de Estudos de Plantas Forrageiras (GEPF) pela dedicação.

Ao grande amigo André Sbrissia pelo auxílio na análise estatística.

Aos amigos Flávia de Andrade e Leonardo Molan pela ajuda na tabulação e discussão dos resultados.

Ao amigo Dimas Estrásulas de Oliveira, pela amizade e orientação na condução das avaliações com n-alcanos.

Ao Professor Dr. Alexandre Vaz Pires e ao Médico Veterinário Juliano Fernandes pelo procedimento cirúrgico de confecção das fístulas esofagianas.

Ao Professor Dr. Flávio Augusto Portela Santos pela concessão dos animais utilizados no experimento.

Aos Professores Dr. Wilson Roberto Soares Mattos e Dr. Luiz Gustavo Nussio oportunidade da convivência e pelo exemplo de dedicação.

À Professora Dra. Ivanete Susin pela solicitude constante e concessão do laboratório usado nas análises de OPG. 
Ao amigo Médico Veterinário Vicente Turino pelos mais variados serviços prestados.

Aos funcionários do Departamento de Produção Animal, Creide, Carlos, Juscelino, Émerson, Laureano, Benedito, pela constante solicitude.

A todos os colegas de Pós-graduação, em especial Marco Antônio, Fábio Maya, Vicente Turino e Lucas Mari pela amizade e companheirismo.

Aos amigos de Brasíla, Rodrigo Naves e Frederico Fontes. De Lavras, Paulinho, Dalton, Carlos Gustavo, Gustavo Tonoli, José Renato, Arley, Braga, André, Rodrigo e Fabiano. E ao grande companheiro Narson.

À Escola Superior de Agricultura "Luiz de Queiroz", através do Departamento de Zootecnia, pela oportunidade de realização do curso de Mestrado.

A Tortuga Cia Zootécnica, pelo auxilio e oportunidade de trabalho conjunto.

À Fundação de Amparo à Pesquisa do Estado de São Paulo (FAPESP), pela concessão da bolsa de estudo e pelo financiamento deste projeto. 


\section{SUMÁRIO}

\section{Página}

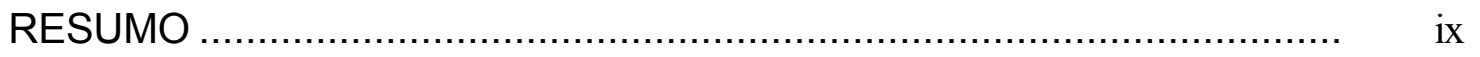

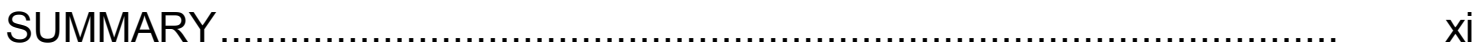

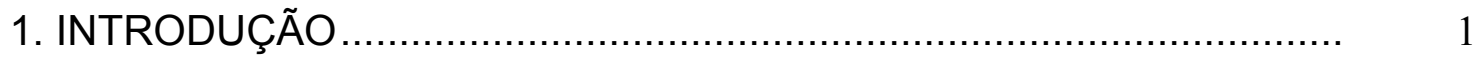

2. REVISÃO DE LITERATURA .........................................................

2.1. Manejo do pastejo.....................................................................

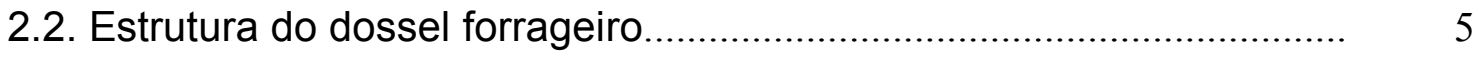

2.3 Consumo …………………………………………………………..... 6

2.4 Comportamento ingestivo ................................................................... 9

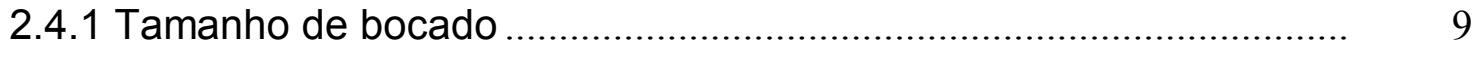

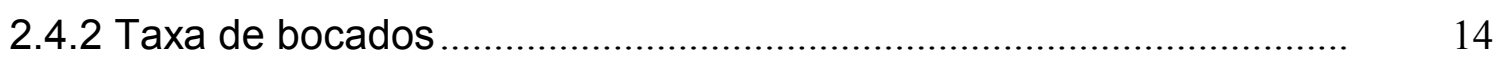

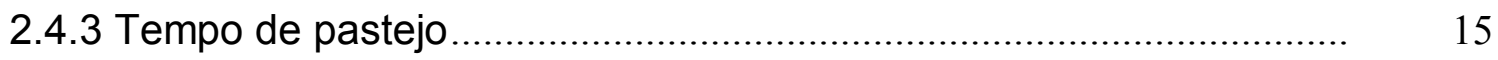

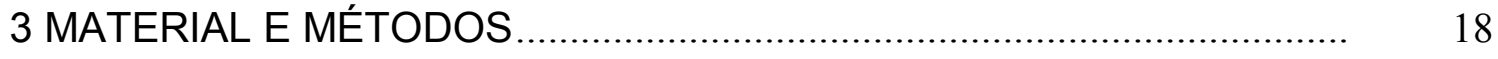

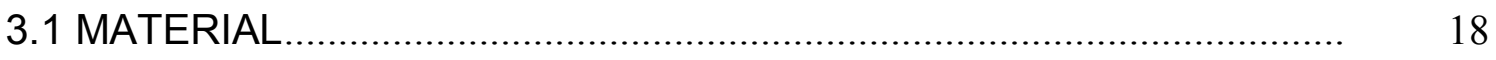

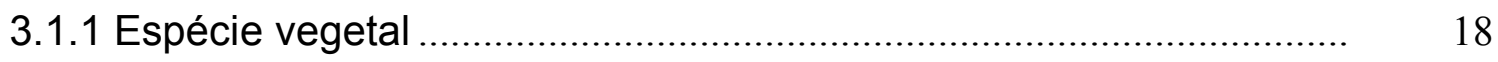

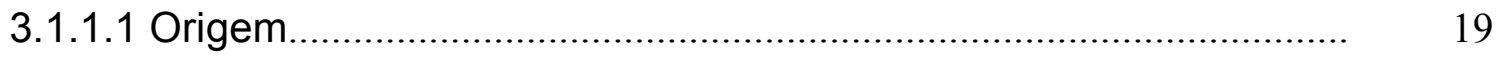

3.1.1.2 Características gerais .................................................................... 


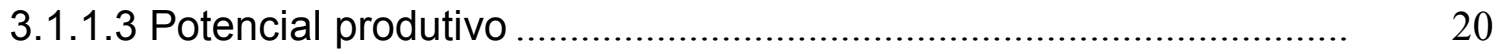

3.1.2 Local do experimento ................................................................... 21

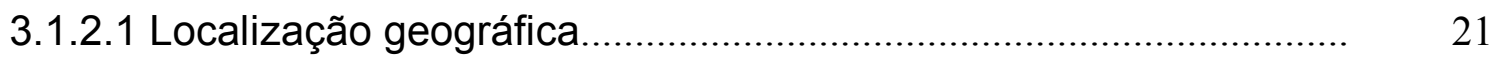

3.1.3 Solo da área experimental ........................................................... 21

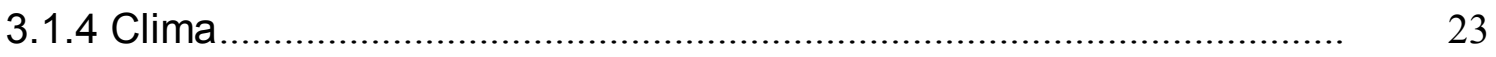

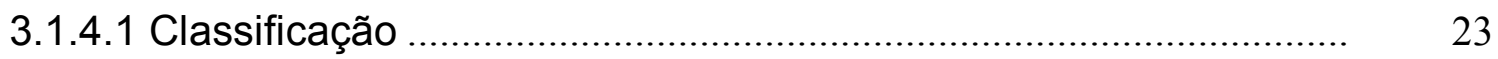

3.1.4.2 Dados climáticos do período de avaliação........................................ 23

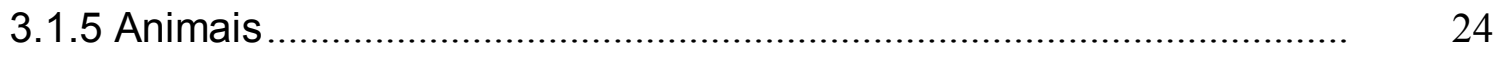

3.2 MÉTODOS

3.2.1 Delineamento experimental e tratamentos ……................................... 25

3.2.2 Instalação das condições experimentais ............................................. 26

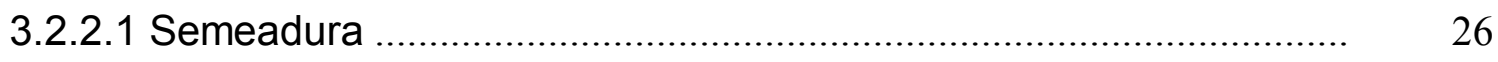

3.2.2.2 Controle de plantas daninhas ......................................................... 27

3.2.2.3 Fertilização e tratos culturais............................................................. 28

3.2.3 Monitoramento das condições experimentais ..................................... 29

3.2.3.1 Alturas dos tratamentos................................................................ 29

3.2.3.2 Fertilização e tratos culturais........................................................... 29

3.2.3.3 Controle do peso vivo no período experimental ............................... 32

3.2.4 O período experimental .................................................................... 32

3.2.5 Avaliações de campo ....................................................................... 33

3.2.5.1 Estrutura do dossel forrageiro ..................................................... 33

3.2.5.2 Massa de forragem e composição botânica e morfológica ............. 34

3.2.5.3 Densidade volumétrica .................................................................. 35

3.2.5.4 Comportamento ingestivo .......................................................... 35

3.2.5.4.1 Tempo de pastejo, ruminação e ócio.............................................. 35

3.2.5.4.2 Taxa de bocados ....................................................................... 37

3.2.5.4.3 Tamanho de bocados ................................................................... 38

3.2.5.4.4 Consumo de forragem (n-alcanos) ….......................................... 39

3.3 Análise estatística ................................................................................. 41

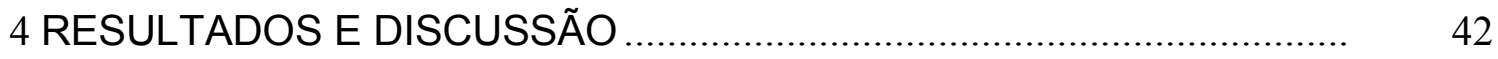




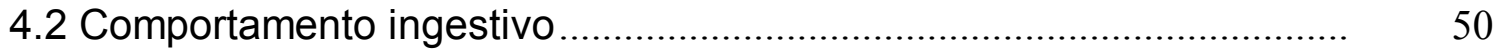

4.2.1 Tamanho de bocado ..................................................................... 50

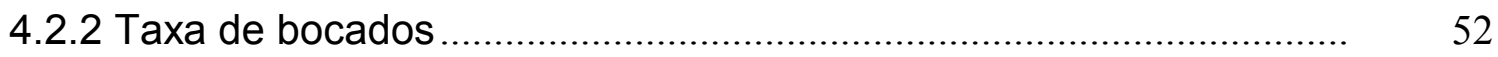

4.3.3 Tempo de pastejo, ruminação e ócio …………………………............ 54

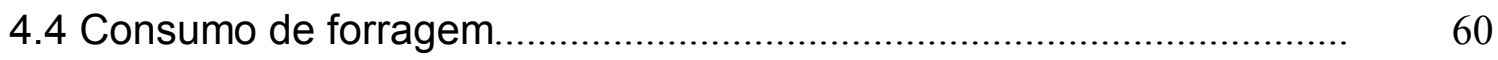

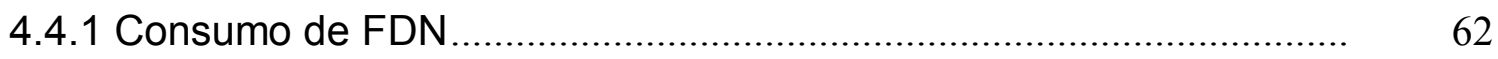

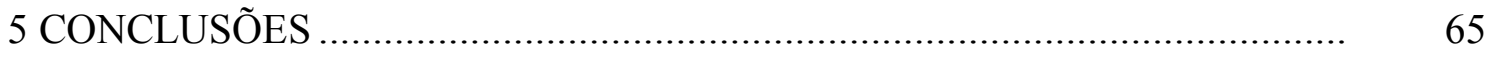

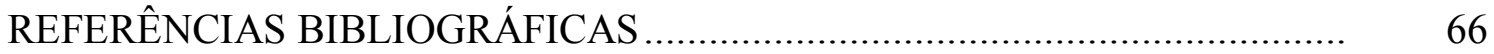




\title{
COMPORTAMENTO INGESTIVO DE BOVINOS EM PASTOS DE
}

\section{CAPIM-MARANDU SUBMETIDOS A REGIMES DE LOTAÇÃO CONTÍNUA}

\author{
Autor: DANIEL OLIVEIRA DE LUCENA SARMENTO
}

Orientador: Prof. Dr. SILA CARNEIRO DA SILVA

\section{RESUMO}

O conhecimento dos aspectos relacionados à interface planta:animal em sistemas de produção em pastagens ganha enorme relevância quando se tem como objetivo principal trabalhar dentro de princípios baseados no equilíbrio e racionalidade do uso dos recursos inerentes ao processo produtivo. Dessa forma, caracterizar os componentes da estrutura do dossel forrageiro e o efeito que os mesmos exercem sobre o comportamento ingestivo de animais em pastejo assume grande importância, uma vez que podem influenciar de forma relevante o consumo de forragem. Dentro desse contexto, o presente trabalho teve como objetivo procurar elucidar aspectos pertinentes à interface planta:animal através da quantificação do tamanho e da taxa de bocado, tempo gasto nas atividades de pastejo, ruminação e ócio pelos animais, e o consumo diário de forragem em pastos de Brachiaria brizantha cv. Marandu pastejados por bovinos em regime de lotação contínua e taxa de lotação variável. $\mathrm{O}$ experimento foi realizado em área do Departamento de Zootecnia da USP/ESALQ, em Piracicaba, SP, entre 01 de novembro de 2001 e 14 de fevereiro de 2003. Os tratamentos corresponderam a quatro alturas de dossel forrageiro $(10,20,30$ e $40 \mathrm{~cm})$ mantidas em steady state, e foram alocados às unidades experimentais segundo um delineamento de blocos completos c 
casualizados, com quatro repetições. Os resultados revelaram uma redução em consumo de forragem com a diminuição da altura do dossel forrageiro $(1,3 ; 1,8$, 1,8 e 2,0 kg MS.kg PV ${ }^{-1}$ para 10, 20, 30 e $40 \mathrm{~cm}$, respectivamente), conseqüência da redução em tamanho de bocado $(0,5 ; 0,8 ; 1,2$ e $1,5 \mathrm{~g}$ MS.bocado $^{-1}$ para 10, 20, 30 e $40 \mathrm{~cm}$, respectivamente). Os animais, na tentativa de tentar compensar a redução em consumo, aumentaram a taxa de bocado $\left(46,3 ; 30,3 ; 23,8\right.$ e 17,5 bocados.minuto ${ }^{-1}$ para 10, 20, 30 e $40 \mathrm{~cm}$, respectivamente) e, na condição de $10 \mathrm{~cm}$ de dossel forrageiro, aumentaram, também, o tempo de pastejo $\left(11,4 ; 10,7 ; 10,6\right.$ e 10,5 horas.dia ${ }^{-1}$ para $10,20,30$ e $40 \mathrm{~cm}$, respectivamente). Concluiu-se que a ingestão de forragem pode ser controlada através de variações em condição e estrutura do dossel forrageiro, situação essa que demonstra o potencial de planejamento e monitoramento de estratégias de pastejo baseadas em metas de condição de dossel para níveis variáveis de exigências nutricionais, épocas do ano e espécie animal. 


\title{
INGESTIVE BEHAVIOUR OF BEEF CATTLE GRAZING Brachiaria brizantha cV. marandu PASTURES SUBMITTED TO CONTINUOUS STOCKING REGIMES
}

\author{
Author: DANIEL OLIVEIRA DE LUCENA SARMENTO \\ Adviser: Prof. Dr. SILA CARNEIRO DA SILVA
}

\section{SUMMARY}

Knowledge of aspects related to plant:animal interface in pastoral systems acquire greater importance when the main objective is to rationalize and optimize the use of any resource available. In that scenario, characterization of structural sward components and their effect on ingestive behaviour of grazing animals is a key element, since they can have a relevant influence on herbage intake. Against this background, the objective of this experiment was to study aspects of the plant:animal interface quantifying bite size, bite rate, time spent on grazing, rumination and rest as well as herbage intake of cattle grazing Brachiaria brizantha cv Marandu pastures submitted to continuous stocking managements. The experiment was carried out at Departamento de Zootecnia, USP/ESALQ, Piracicaba, SP, from 01 November 2001 until 14 February 2003. Treatments corresponded to four steady state conditions characterized by sward surface heights (SSH) of $10,20,30$ and $40 \mathrm{~cm}$, assigned to experimental units according to a complete randomized block design, with four replications. The results revealed a reduction in herbage intake with decreasing $\mathrm{SSH}(1.3,1.8$, 1.8 and $2.0 \mathrm{~kg}$ DM.kg LW ${ }^{-1}$ for $10,20,30$ and $40 \mathrm{~cm}$, respectively), 
consequence of a reduction in bite size $\left(0.5,0.8,1,2\right.$ and $1.5 \mathrm{~g} \mathrm{DM}^{\mathrm{bite}}{ }^{-1}$ for 10 , 20, 30 and $40 \mathrm{~cm}$, respectively). Animals, in an attempt to compensate the decrease in herbage intake, increased their bite rate $(46.3,30.3,23.8$ and 17.5 bites.minute $^{-1}$ for $10,20,30$ and $40 \mathrm{~cm}$, respectively) and, for the $10 \mathrm{~cm} \mathrm{SSH}$, increased, also, their grazing time $\left(11.4,10.7,10.6\right.$ and 10.5 hours.day $^{-1}$ for 10 , 20,30 and $40 \mathrm{~cm}$, respectively). It was concluded that herbage intake can be controlled by variations in sward structure and condition, which points to the potential for planning and monitoring grazing strategies based on sward targets for variable levels of animal requirements, time of the year and animal species. 


\section{INTRODUÇÃO}

Em tempos onde se busca o uso racional de recursos, sejam eles de ordem financeira, ambiental ou intelectual o conhecimento de relações causa:efeito é fundamental. No setor produtivo, mais especificamente da produção animal em pastagens, essa realidade adquire importância ainda maior em função da necessidade de promover produtividade de forma sustentável e harmoniosa com o meio ambiente. Dessa forma, uma exploração planejada e alicerçada em princípios baseados em conhecimento científico passa a ter caráter primordial.

Com base no exposto, é importante que sejam desvendados os "mistérios" da ecofisiologia das plantas forrageiras tropicais quando submetidas a desfolhação por animais para que seja possível estabelecer estratégias de manejo baseadas em conhecimento científico e não em empirismo. Essa resposta das plantas forrageiras em pastagens interfere de forma direta no comportamento ingestivo e desempenho dos animais que, por sua vez, alteram as características morfológicas e fisiológicas do dossel forrageiro modificando os padrões de respostas de plantas e animais. Assim, o conhecimento e entendimento das relações existentes entre plantas e animais em sistemas de pastagens torna-se um quesito essencial para o estabelecimento de estratégias de manejo do pastejo condizentes com sistemas equilibrados e ecologicamente sustentáveis.

O presente trabalho teve como objetivo estudar a interface planta:animal, especialmente o comportamento ingestivo de bovinos de corte 
em pastos de Brachiaria brizantha (Hochst ex A. Rich) Stapf. cv Marandu submetidos a condições de dossel forrageiro (alturas de 10, 20, 30 e $40 \mathrm{~cm}$ ) mantidas "constantes" através de lotação contínua e taxa de lotação variável. 


\section{REVISÃO}

\subsection{Manejo do pastejo}

Num ambiente caracterizado pelo antagonismo em se manter área foliar suficiente para assegurar interceptação eficaz da luz incidente e colher a forragem produzida da forma mais eficiente e com o melhor valor nutritivo possível, reduzindo perdas por senescência, encerra-se o grande e maior conflito da produção animal em pastagens: encontrar o balanço ótimo entre os requerimentos concorrentes de plantas e animais.

A dinâmica da desfolhação de plantas forrageiras está sujeita a interações de diversas naturezas, cabendo ao manejador do sistema equacionar todas essas interações e elaborar uma estratégia de desfolhação condizente com a planta forrageira sendo explorada e com as metas de produtividade almejadas (Gonçalves, 2002). Essa estratégia de manejo do pastejo assume maior importância quando considerada a afirmação de Hodgson et al. (1981) de que mudanças mais significativas ocorrem dentro da relação de aproveitamento da forragem (produzido $x$ colhido $x$ senescido) que dentro da produção total da mesma sob diferentes condições de intensidade e freqüência de desfolhação (Gonçalves, 2002).

Segundo Mcmeekan (1956), para a obtenção de uma alta produção animal em pastagens três condições básicas devem ser atendidas: (a) produção de uma grande quantidade de forragem de bom valor nutritivo, (b) grande proporção da forragem produzida deve ser colhida pelos animais, e (c) elevada eficiência de conversão dos animais, ou seja, deve haver um equilíbrio 
harmônico entre as três fases do processo de produção: crescimento, utilização e conversão (Hodgson, 1990).

A primeira condição (produção de forragem - crescimento) é passível de ser manipulada, mas de forma limitada, uma vez que o processo de fluxo de tecidos em comunidades de plantas forrageiras é modulado por características de origem intrínseca ao genótipo da planta (características morfogênicas), fortemente influenciadas por variáveis de ambiente (Lemaire, 1997) e sobre as quais ações do manejador são pouco efetivas. O mesmo ocorre no tocante à terceira condição, ou seja, a conversão da forragem colhida em produto animal, uma vez que a magnitude dos incrementos possíveis é relativamente pequena (Hodgson, 1990). De acordo com Mertens (1994), o desempenho animal é função do consumo de nutrientes digestíveis e metabolizáveis, uma vez que cerca de 60 a 90\% das variações em desempenho são explicadas pelas variações correspondentes em consumo e apenas 10 a $40 \%$ pelas variações correspondentes em digestibilidade.

Dessa forma, a utilização torna-se o ponto central de discussão como principal fator a ser considerado no manejo do pastejo, onde ser eficiente requer o entendimento das inter-relações entre as características da pastagem e o processo de colheita do pasto, assim como o efeito que as mesmas exercem sobre a estrutura do dossel forrageiro e, de forma cíclica, sobre o próprio comportamento dos animais em pastejo. Na verdade, o manejador deve estar, sempre, preparado para equilibrar ineficiências visando alcançar um balanço ótimo entre crescimento, utilização e conversão (Sbrissia \& Da Silva, 2001). Como conseqüência, não existe um modelo específico de sistema de produção a ser adotado para condições particulares, mas sim a necessidade de conhecer os fatores de produção existentes na base física disponível e combiná-los da melhor forma possível, buscando a solução ótima para a realidade existente (Da Silva \& Sbrissia, 2000).

Contudo, a eficiência de colheita de pastagens acaba sendo esquecida em função da constante busca por altos valores de desempenho 
animal resultando, na maioria das vezes, numa baixa produção animal por hectare e um excesso de perda de forragem por senescência (Leafe \& Parsons, 1983).

\subsection{Estrutura do dossel forrageiro}

Segundo Laca \& Lemaire (2000), a estrutura do dossel forrageiro pode ser definida como a distribuição e arranjo dos componentes da parte aérea das plantas dentro de uma comunidade, e várias são as características utilizadas para descrevê-la: altura, densidade populacional de perfilhos, densidade volumétrica ("bulk") da forragem, distribuição da fitomassa por estrato, ângulo foliar, índice de área foliar, relação folha:haste, etc..

Características estruturais determinam o grau de pastejo seletivo exercido pelos animais, assim como a eficiência segundo a qual a forragem é colhida, determinando a quantidade total de nutrientes ingeridos (Stobbs, 1973b). Após desfolhação seletiva, o animal modifica a composição dos tecidos remanescentes e a competição intra e/ou interespecífica dos constituintes da vegetação, alterando o ambiente do futuro bocado (Carvalho et al., 1999). Dessa forma, variações nos processos de pastejo mediante modificações na estrutura do dossel podem influenciar de forma relevante o consumo de forragem.

Segundo Hodgson (1990), os animais respondem mais consistentemente a variações em altura do dossel que em massa de forragem. Nos estudos com plantas forrageiras de clima temperado, as relações entre altura do dossel com o consumo de forragem e desempenho animal são bem evidentes, demonstrando que aumentos em altura, desde que não haja decréscimo no valor nutritivo da forragem, proporcionam incrementos no consumo individual bem como no desempenho de diferentes categorias animais (Hodgson, 1990). Nesse contexto, o trabalho de Stobbs (1973a \& b) sugere que, ao contrário do que acontece em pastagens de clima temperado, a 
densidade volumétrica da forragem parece ser o principal componente da estrutura do dossel a determinar a taxa de consumo em plantas forrageiras tropicais e não a altura (Hodgson et al., 1994).

O processo de utilização e colheita da forragem pelos animais em pastejo (quantidade e valor nutritivo) é função do entendimento relativo à interface planta:animal, característica determinante e condicionadora das relações de causa:efeito entre práticas de manejo do pastejo e desempenho animal. Portanto, o conhecimento da interação entre estrutura do dossel forrageiro e comportamento ingestivo é um passo fundamental a fim de que o manejo do pastejo possa ser considerado dentro de uma realidade de eventos fisiológicos, propiciando que tomadas de decisão sejam amparadas por critérios científicos baseados na forma e função das plantas forrageiras e na maneira pela qual estas influenciam e determinam o consumo de forragem de animais em pastejo.

\subsection{Consumo}

As teorias que explicam o controle do consumo voluntário dos ruminantes admitem ser este mecanismo um produto da ação integrada ou isolada de fatores físicos e fisiológicos. A demanda energética do animal define o consumo de dietas de alta densidade calórica, ao passo que a capacidade física do trato gastrintestinal determina o consumo de dietas de baixo valor nutritivo e baixa densidade energética (Van Soest, 1994). A fibra insolúvel em detergente neutro (FDN) pode ser utilizada para caracterizar, na dieta, a expressão desses dois mecanismos de controle do consumo numa mesma escala, por estar relacionada diretamente ao efeito de enchimento do rúmen e inversamente à concentração energética da dieta (Mertens, 1992). Segundo Mertens (1994), em plantas forrageiras com valores de FDN variando de 25 a $70 \%$ da matéria seca, o limite máximo de ingestão de FDN ocorreria quando o consumo atingisse $1,25 \%$ do peso vivo.dia ${ }^{-1}$, uma vez que acima desse valor a 
ingestão de forragem seria limitada pelo aspecto físico.

No entanto, esses mecanismos apenas são válidos quando o alimento, no caso forragem, já se encontra no interior do trato digestivo, o que não ocorre com animais em pastejo. Nesse ecossistema o animal depara-se com o desafio de se alimentar em um ambiente altamente heterogêneo, com enorme variabilidade espaço-temporal na oferta e demanda de nutrientes (Carvalho, 1999). O mesmo autor enalteceu que ações do animal incluem a procura e a manipulação da forragem a ser ingerida, o que é função de uma demanda nutricional a ser atendida e uma limitação de tempo para tanto.

Nessas condições a explanação proposta por Poppi et al. (1987) acerca dos fatores que afetam o consumo de forragem é a que mais se enquadra a animais em ambiente de pastagem. Segundo esses autores, a ingestão de forragem é regida por fatores nutricionais e não nutricionais. Os fatores não nutricionais seriam aqueles relacionados ao comportamento ingestivo dos animais em pastejo, e os fatores nutricionais aqueles relacionados a aspectos inerentes à digestibilidade, composição química da forragem e fatores metabólicos. Levando-se em conta que os fatores não nutricionais sofrem influência direta da estrutura do dossel forrageiro e da oferta de forragem, e as características bromatológicas inerentes às gramíneas forrageiras tropicais, dificilmente os fatores nutricionais determinaram $o$ consumo de forragem de animais em pastejo.

O desempenho animal é função direta do consumo de matéria seca digestível. Noller et al. (1996) apontaram que o consumo de matéria seca produz mais impacto na produção animal do que variações na composição química ou disponibilidade dos nutrientes. Forragens com valores de fibra insolúvel em detergente ácido (FDA) em torno de $30 \%$ ou menos possuem consumo elevado, enquanto aquelas com teores acima de $40 \%$ possuem menor ingestão. $O$ consumo diário mínimo de pasto é estimado em torno de $2 \%$ do peso vivo devido à seleção, mas poderá ser ainda mais reduzido se houver restrição física e/ou o valor nutritivo da forragem for baixo (Nussio et al., 1998). 
Forbes (1993) concluiu que os ruminantes em geral são capazes de controlar seu consumo energético de maneira semelhante aos animais de estômago simples, desde que a densidade de nutrientes da dieta seja suficientemente alta para que as restrições físicas não interfiram.

Outro fator determinante do consumo num sistema de produção animal em pastagens é a oferta de forragem (Da Silva \& Pedreira, 1996). Os níveis máximos de consumo e desempenho animal estão relacionados com uma oferta de forragem de cerca de duas a três vezes a necessidade diária do animal (Hodgson, 1990). O mesmo autor cita, ainda, que ofertas diárias de matéria seca de 10 a $12 \%$ do peso vivo permitiriam o máximo desempenho individual de animais em pastejo. Em contrapartida, com altas ofertas, são comuns níveis de utilização de apenas um terço da forragem em oferta, gerando perdas excessivas que diminuem a produtividade do sistema de produção como um todo (Da Silva \& Pedreira, 1996).

A relação entre o consumo e a abundância de forragem é denominada resposta funcional (Demment \& Laca 1994), sendo que a taxa de consumo aumenta com a altura ou biomassa do dossel até atingir uma assíntota decorrente da saturação da capacidade do animal em processar o alimento ingerido (Gordon \& Illius, 1992). Assim, a compreensão da regulação do consumo, relacionada à interface planta:animal, deve receber um enfoque reducionista (mecanicista), o qual pode ser melhor demonstrado desmembrando-se o consumo em variáveis de menor escala (Allden \& Whittaker, 1970; Hodgson, 1982).

Dentre os inúmeros fatores que interagem num ecossistema de pastagens, o comportamento ingestivo assume grande importância na pesquisa com plantas forrageiras, já que existe um efeito direto deste sobre o consumo e, conseqüentemente, no desempenho animal. 


\subsection{Comportamento ingestivo}

O ecossistema de pastagens é caracterizado por uma série de interrelações, e uma delas compreende a interface planta-animal, regida por relações causa:efeito onde diferentes estruturas de dossel forrageiro determinam padrões distintos de comportamento e desempenho animal.

O consumo diário sob condições de pastejo é função de variáveis associadas ao comportamento do animal que, segundo uma visão mecanística, é descrito através das variáveis tempo de pastejo, taxa de bocados e tamanho de bocado (Allden \& Whittaker, 1970). A ingestão diária de forragem é o resultado do produto entre o tempo gasto pelo animal na atividade de pastejo e a taxa de ingestão de forragem durante esse período que, por sua vez, é o resultado do produto entre o número de bocados por unidade de tempo (taxa de bocados) e a quantidade de forragem apreendida por bocado (tamanho de bocado) (Erlinger et al., 1990). Assim, o consumo diário pode ser influenciado por variações em qualquer desses parâmetros. Essa proposição influenciou uma série de trabalhos que vieram destacar a importância da estrutura do dossel forrageiro como determinante e condicionadora da ingestão de forragem de animais em pastejo (Stobbs, 1973a, b).

Um exemplo da relação entre essas variáveis e a estrutura do dossel forrageiro pode ser dado imaginando-se um cenário de baixa oferta de forragem. A resposta clássica nessas condições é uma diminuição do tamanho do bocado e um aumento na taxa de bocados e/ou no tempo de pastejo (Penning, 1986), sendo que esta compensação, no entanto, estaria limitada a apenas $15 \%$ do consumo diário (Coleman, 1992).

\subsubsection{Tamanho de bocado}

A ingestão de forragem por bocado é muito sensível a variações estruturais, particularmente em altura do dossel forrageiro (Cosgrove, 1997). 
Quando a ingestão por bocado é reduzida, ocorre uma queda correspondente na taxa de ingestão a menos que um incremento compensatório na taxa de bocados seja observado. Desse mesmo modo, a ingestão diária de forragem também será afetada se qualquer redução na taxa de ingestão não puder ser compensada por um incremento no tempo de pastejo (Hodgson, 1990).

O tamanho do bocado é a variável mais importante na determinação do consumo de animais em pastejo e a mais influenciada pela estrutura do dossel forrageiro (Hodgson, 1985). Trabalhos pioneiros com plantas forrageiras tropicais revelaram a importância do tamanho de bocados relativamente aos demais componentes do comportamento ingestivo (Stobbs, 1973a, b; Chaccon \& Stobbs, 1976), indicando padrão análogo àquele descrito para plantas de clima temperado. Desenvolvimentos subseqüentes nessa linha de pesquisa levaram a um aprofundamento no conhecimento dessa variável chave. Hodgson (1985) propôs uma representação esquemática onde o peso do bocado seria o produto entre a densidade volumétrica da forragem e o volume do bocado no estrato pastejado, sendo este último o produto entre sua área $\mathrm{e}$ sua profundidade. Para Hodgson et al. (1994) essas simples equações forneceriam uma firme base conceitual para compreensão da influência das características do dossel forrageiro sobre o comportamento ingestivo de animais em pastejo.

As dimensões do bocado de animais em pastejo (área $\mathrm{e}$ profundidade) são importantes tanto para a planta quanto para o animal. No caso de comunidades de plantas, elas definem a profundidade e área da camada de forragem removida, definindo, portanto, a intensidade e o padrão espacial da desfolhação (Edwards et al., 1995). Para o animal, a dimensão do bocado, junto com a densidade volumétrica do estrato pastejado, define o tamanho do bocado, que é a variável mais influente sobre o consumo animal (Coleman, 1992). Portanto, quaisquer alterações no peso do bocado, seja por uma resposta a variações em estrutura do dossel, seja por uma decisão comportamental (Newman et al., 1994b), passam necessariamente por uma 
alteração na área ou profundidade do bocado. Tanto a área quanto a profundidade do bocado são variáveis cujas definições estão mais associadas ao arranjo espacial da comunidade de plantas do que a medidas relacionadas ao animal. A profundidade do bocado corresponde à diferença entre a altura inicial e a altura residual medida após o pastejo, e a área do bocado seria a área total pastejada dividida pelo número de bocados realizados (Ungar, 1996).

Segundo Carvalho (1997), vários estudos nas mais diversas condições concluíram que a profundidade do bocado guarda uma relação positiva com a altura do dossel forrageiro e negativa em relação à densidade volumétrica da forragem (Gordon \& Lascano, 1993). Experimentos em micropastagens construídas em pranchas (Black \& Kenney, 1984), leivas de pastagem oferecidas a animais em gaiolas (Gordon et al., 1996), gaiolas de pastejo (Burlinson et al., 1991), perfilhos marcados (Wade, 1991) e quadrados marcados na pastagem (Edwards et al., 1995) foram unânimes em concluir que quanto maior a altura do dossel forrageiro maior a profundidade de bocado em ovinos (Burlinson \& Hodgson, 1985), bovinos (Mursan et al., 1989), caprinos (Betteridge et al., 1994) e eqüinos (Hughes \& Gallagher, 1993). Essa relação ocorreu independentemente do método de pastejo empregado e em espécies morfologicamente contrastantes como o azevém perene (Lolium perenne L.) e o trevo branco (Trifolium repens L.) (Wade, 1991; Edwards et al., 1995). Na grande maioria dos trabalhos, a relação entre a profundidade do bocado e a altura do dossel forrageiro foi linear e positiva, embora tenham existido exceções onde essa relação foi descrita de forma assintótica (Mitchell et al., 1991; Laca et al., 1992b; Parsons et al., 1994).

Segundo Hodgson et al. (1994), pouco ainda se conhece a respeito de características morfológicas das plantas que possam controlar a relação entre altura do dossel forrageiro e a profundidade do bocado. Por outro lado, vários trabalhos apontam para o comprimento/posicionamento da bainha (pseudocaule) como um fator que limitaria fisicamente incrementos na profundidade do bocado (Bartharam, 1981; Arias et al. 1990; Flores et al., 
1993). Apesar dessa falta de consenso, parece difícil negar a existência de alguma relação entre as diferenças observadas no eixo vertical dos componentes morfológicos das plantas e os reflexos desses sobre a profundidade do bocado (Carvalho, 1997). Contudo, segundo Wright \& Ilius(1995), o pseudocaule oferece maior resistência à desfolhação que a lâmina foliar e, em se tratando do mesmo tecido (lâmina foliar, por exemplo), a resistência parece ser maior na base que no ápice (Greemberg et al., 1989). Mas nesse ponto, características inerentes à resistência a desfolhação são ainda pouco conhecidos. Segundo Illius et al. (1995), observa-se um maior dispêndio de energia na mastigação que na remoção da forragem colhida por animais em pastejo.

A área do bocado apresenta, de uma forma geral, menor sensibilidade a variações em estrutura do dossel forrageiro (Hodgson et al., 1994). Esta variável diminui linearmente com a densidade volumétrica da forragem e aumenta de forma quadrática com a sua altura (Gordon \& Lascano, 1993). Esse padrão de resposta pode ter como explicação as limitações anatômicas dos animais associadas às dimensões de suas maxilas (Illius \& Gordon, 1997). Mesmo atingindo uma assíntota, a área do bocado nessas condições é normalmente maior que a área da boca dos animais. Em bovinos isso seria esperado uma vez que utilizam a língua como um mecanismo de maximização da área do bocado. No entanto, a área do bocado em ovinos também pode ser superior às dimensões de sua boca em função de movimentos de cabeça horizontais quando da apreensão da forragem (Edwards et al., 1995). É possível imaginar também uma diminuição da área do bocado como resposta a situações que possam exigir um esforço maior na desfolhação, explicando-se a relação linear e inversa entre a área do bocado e a densidade volumétrica da forragem (Carvalho, 1997).

Edwards et al. (1995), trabalhando com plantas forrageiras de clima temperado, revelaram que cerca de $50 \%$ da altura do dossel forrageiro é removida durante o pastejo, o que dá suporte ao conceito de proporcionalidade 
no processo de remoção de forragem do pasto pelos animais. A profundidade do bocado é a mesma tanto para azevém perene quanto para trevo branco apesar de serem morfologicamente contrastantes, sendo que a área do bocado em trevo branco é maior do que no azevém (Edwards et al., 1995). A área do bocado é proporcionalmente pouco alterada ao longo do perfil pastejado, sendo as grandes alterações no volume do bocado decorrentes do efeito direto da profundidade do mesmo (Edwards et al., 1995). Tal conceito de proporcionalidade parece ser mantido em se tratando de plantas tropicais, como verificado por Gonçalves (2002) em trabalho com Brachiaria brizantha (Hochst ex A. Rich) Stapf. cv. Marandu, onde 33\% da altura do dossel forrageiro foi removida pelo pastejo independentemente da altura do pasto estudada. Em termos absolutos, a profundidade do bocado é significativamente alterada e diminuída conforme o animal pasteja próximo ao nível do solo. O limite de pastejo, altura a partir da qual existiria um impedimento físico ao bocado, seria dado pelo intercepto da regressão entre a profundidade do bocado e a altura do dossel forrageiro (Carvalho, 1997).

De acordo com Carvalho (1997), se a profundidade do bocado é a variável que mais responde às alterações em estrutura do dossel forrageiro, significa que seja ela a principal variável determinante do volume do bocado. Considerando-se que a estrutura do dossel não pode ser alterada no momento do bocado porque é uma característica inerente à pastagem, pode-se concluir que o volume do bocado é a mais importante ferramenta de que dispõe o animal para controlar a quantidade e o valor nutritivo da forragem que será ingerida, o que seria o peso do bocado em última análise (Carvalho, 1997). Nessa condição, a profundidade do bocado seria o principal determinante do peso do bocado (Carvalho, 1997). As evidências acumuladas a partir de estudos realizados em condições altamente controladas confirmam a influência dominante da profundidade na determinação do peso do bocado, e da altura do dossel forrageiro sobre a profundidade do bocado. Porém, os mesmos enfatizam a necessidade de estudos em pastagens "verdadeiras" para a 
determinação de mecanismos de controle das dimensões do bocado (Hodgson et al., 1994).

Cabe ressaltar, ainda, que a grande maioria dos resultados obtidos restringe-se a espécies de clima temperado, particularmente azevém perene, sendo que experimentos com espécies de clima tropical e sub-tropical são praticamente inexistentes.

\subsubsection{Taxa de bocados}

O estudo da velocidade de ingestão, também conhecida como taxa de consumo instantâneo, relaciona-se diretamente com os efeitos da estrutura do dossel forrageiro sobre o comportamento ingestivo de animais em pastejo, estando o foco centrado no processo de ingestão de forragem. A quantidade de forragem ingerida diariamente é o produto entre tempo de pastejo e taxa de ingestão de forragem durante o pastejo. A taxa de ingestão de forragem é o produto entre a taxa de bocados e do tamanho de bocado (Carvalho, 1997).

Assim como as outras variáveis comportamentais, a freqüência média dos bocados de apreensão realizados por animais em pastejo está ligada a características inerentes a estrutura do dossel forrageiro, mas também possui íntima ligação com variações nos padrões do principal determinante da quantidade de alimento consumida pelo animal em pastejo, o tamanho de bocado (Hodgson et al., 1994; Cosgrove, 1997). Esses reflexos podem ser observados muitas vezes como respostas a reduções na oferta de forragem, altura do dossel forrageiro, densidade volumétrica e redução da proporção de folhas verdes (Stobbs, 1973a, b).

O número total de movimentos mandibulares de um animal ao longo do dia tem se revelado semelhante existindo, no entanto, variações relacionadas à quantidade de movimentos mandibulares destinados a apreensão e manipulação da forragem (Penning et al., 1991a, b). A teoria inicial de que o animal aumentaria a taxa de bocados na tentativa de compensar a 
diminuição do peso do bocado se explicaria, na verdade, por uma estratégia do animal de diminuição do número de bocados de mastigação, mantendo o número total de movimentos mandibulares. Na situação contrária, onde o peso de bocado é elevado, maior a necessidade de mastigação e, portanto, o número de bocados de apreensão deve ser reduzido (Ungar, 1996), sendo esta uma provável explicação para algumas situações onde o aumento no tamanho do bocado não afeta a taxa de consumo instantânea (Hodgson et al., 1994).

Movimentos mandibulares de apreensão e de mastigação podem ser vistos como atividades competitivas entre si (Spalinger \& Hobbs, 1992). Em bovinos, ainda, há um fator complicador, que é o fato de existirem bocados compostos, nos quais as atividades de manipulação e mastigação são realizadas de forma concomitante, podendo perfazer até $90 \%$ do total de movimentos mandibulares em situações de alta oferta de forragem (Laca et al., 1993, 1994).

\subsubsection{Tempo de pastejo}

As variáveis de comportamento não são de simples quantificação, pois englobam a questão de como o animal percebe e se movimenta no ambiente de pastejo. A morfologia do aparelho locomotor e o peso do animal são fatores importantes na determinação do tempo de encontro com bocados potenciais (Shipley et al., 1996), de forma que o tempo de pastejo reflete a facilidade de apreensão e remoção de forragem. No uso do tempo em pastejo, os animais procuram ser eficientes uma vez que buscam bocados potencias enquanto mastigam a forragem apreendida em bocados anteriores (Prache, 1997).

Segundo Prache \& Peyraud (1997), algumas características associadas à planta relacionadas à facilidade de colheita da forragem pelo animal são: a altura do dossel forrageiro, a massa de forragem presente por 
unidade de volume, a baixa fibrosidade das lâminas foliares, a disposição espacial dos tecidos vegetais preferidos, a presença de barreiras à desfolhação, tais como bainhas e colmos, e o seu teor de matéria seca. Essas são todas características inerentes à estrutura do dossel forrageiro, e determinarão as estratégias e mecanismos utilizados pelos animais durante o pastejo.

Deve-se considerar $o$ fato da dependência existente entre a desfolhação realizada pelo animal e elementos inerentes a estrutura do dossel, onde determinados componentes da planta são preferidos em relação a outros, folhas em relação a hastes, por exemplo (L 'Huillier et al., 1986). Segundo O'Reagain \& Mentis (1989), plantas altas, com uma maior proporção de folhas, que apresentam maior facilidade de serem rompidas, e altos teores de nitrogênio são escolhidas preferencialmente por bovinos. Portanto, a qualidade de uma planta forrageira em ser apreendida é parte importante num processo que é freqüentemente limitado pelo tempo (Carvalho, 1999). Esta característica traduz a facilidade com que a forragem é ingerida pelo animal, sendo um importante determinante não somente do consumo diário, mas também, do processo de seleção da dieta (Prache \& Peyraud, 1997).

A manipulação do bocado compreende $\mathrm{o}$ ato de apreender a forragem, trazendo-a para dentro da boca e cortando-a através de movimentos de cabeça, lábios (ovinos e caprinos) e língua (bovinos), além dos movimentos de mastigação e deglutição do bolo alimentar. Em pastagens cujo valor nutritivo e disponibilidade não são limitantes, assume-se muitas vezes que o tempo de procura possa ser insignificante, pois o animal mastiga a forragem enquanto se movimenta de uma estação alimentar para outra (Laca \& Demment, 1992). De forma geral, quanto maior a altura do dossel forrageiro e maior a massa de forragem, menor o número de movimentos de apreensão e maior os de mastigação (Penning et al., 1994). Em contrapartida, quanto menor a altura das plantas, mais densa é a forragem e menos efetiva é a capacidade dos animais em ampliar a quantidade de forragem trazida até a boca (Laca et al., 1992). O consumo diário estaria, então, na dependência do tempo de pastejo, que é 
função de uma série de fatores, dentre os quais a taxa de passagem e a relação consumo/requerimento animal (Carvalho, 1997).

O tempo de pastejo é normalmente de 8 horas, podendo atingir até 16 horas em situações extremas (Hodgson et al., 1994), sendo que nesses casos o processo de digestão da forragem passaria a ter caráter mais importante (Laca \& Demment, 1992). Isso ocorre porque a cada dia o animal distribui o seu tempo entre as atividades de pastejo, ruminação e ócio, sendo observados de três a cinco picos de pastejo no decorrer do dia, os mais intensos ocorrendo no início da manhã e no final da tarde (Cosgrove, 1997). Segundo Krysl \& Hess (1993), os animais realizam 65 a 100\% de sua atividade de pastejo entre as 6 e as 19 horas do dia.

Com base no exposto fica clara a importância do consumo de forragem sobre o desempenho animal em pastagens. No entanto, tanto consumo como produção e utilização da forragem produzida dependem da relação entre características da interface planta-animal, razão pela qual o equilíbrio ótimo entre as fases do processo produtivo em sistemas de pastagens (crescimento, utilização e conversão) somente poderá ser atingido quando do conhecimento e compreensão dessas relações. O presente trabalho teve como objetivo procurar elucidar aspectos pertinentes à interface planta:animal em pastos de Brachiaria brizantha cv. Marandu, visando propiciar condições para o entendimento do processo de colheita de forragem pelos animais, informação básica para o planejamento e definição de práticas de manejo do pastejo racionais e eficientes, compatíveis com sistemas de produção animal ecologicamente viáveis. 


\section{MATERIAL E MÉTODOS}

\subsection{Material}

\subsubsection{Espécie vegetal}

A espécie estudada classifica-se, de acordo com o "Sistema Cronquist" (Cronquist, 1988) como divisão Magnoliophyta; classe Liliopsida; subclasse Commelinidae; ordem Cyperales; família Poaceae; subfamília Panicoideae; Tribo Panicodae; subtribo Paniceae; gênero Urochloa; espécie Urochloa brizantha (Hochst. ex A. Rich.) Webster; variedade Urochloa brizantha (Hochst. ex A. Rich.) Webster var Marandu.

A espécie em questão é tradicionalmente conhecida como Brachiaria brizantha (Hochst. ex A. Rich) e possui diversas denominações regionais como: brizantão, brizantha, braquiarão, capim Marandu, capim Ocinde e Marandu (Renvoize et al., 1996). No entanto, Webster (1988), revisando diversos gêneros de gramíneas, concluiu que várias espécies do gênero Brachiaria pertenciam na verdade ao gênero Urochloa. Da mesma maneira, Morrone \& Zuloaga (1992), numa extensa revisão sobre os dois gêneros, concluíram que no continente americano o gênero Brachiaria se fazia representar, até aquela data, por apenas uma espécie introduzida: Brachiaria eruciformis (Smith) Griseb.. Assim, a maioria das espécies tratadas comumente como Brachiaria (i.e., B. brizantha, B. decumbens, B. humidicola, B. ruziziensis, entre outras) fazem parte atualmente do gênero Urochloa. 
Dessa forma, a fim de se manter o rigor científico e, ao mesmo tempo, evitar confusão relativa à nomenclatura, o nome utilizado, deste ponto em diante, será capim-Marandu.

\subsubsection{Origem}

De acordo com Nunes et al. (1985), o capim-Marandu é um ecotipo, originário de regiões vulcânicas da África tropical, que durante muitos anos foi cultivado no Brasil, na região do município de Ibirarema, Estado de São Paulo. Em 1977 a Estação de Pesquisas em Pastagens de Marandela - Zimbabwe, na África, enviou amostras do material vegetal ao CNPGC - Centro Nacional de Pesquisa de Gado de Corte, da EMBRAPA - Empresa Brasileira de Pesquisa Agropecuária, situado no município de Campo Grande, Estado do Mato Grosso do Sul, onde passou a ser estudado sob o código de acesso BRA-000591. No ano de 1979 o CPAC - Centro de Pesquisa Agropecuária do Cerrado, também da EMBRAPA, situado no município de Planaltina, Distrito Federal, recebeu parte do material para estudo. No ano de 1984 houve o lançamento oficial da planta forrageira, numa parceria entre o CPAC e o CNPGC, servindo esta como mais uma alternativa forrageira aos pecuaristas brasileiros (Nunes et al., 1985; Renvoize et al., 1998).

\subsubsection{Características gerais}

O capim-Marandu chamou a atenção dos técnicos pelas suas características específicas como: plantas sempre robustas, hábito de crescimento cespitoso, altura de 1,5 a 2,5 metros, colmos iniciais de crescimento prostrado, mas com emissão de perfilhos predominantemente eretos. Seus rizomas são muito curtos e encurvados. Os colmos floríferos são eretos, com perfilhamento nos nós superiores, levando à proliferação de inflorescências que atingem até 40 centímetros de comprimento, geralmente 
com 4 a 6 racemos. Suas lâminas foliares são largas e longas, glabras na face superior, com pubescência na face inferior, e bordos não cortantes. As bainhas são pilosas, enquanto os entrenós apresentam pêlos na porção apical (Nunes et al., 1985). Sua capacidade de adaptação às mais variadas condições de ambiente (Ghisi \& Pedreira, 1987), especialmente em sistemas de produção com reduzido emprego de insumos, é a responsável por sua expansão e expressividade (Andrade, 1994).

Segundo Santos Filho (1996), é uma das plantas forrageiras mais utilizadas em todo o país, perfazendo mais de $20 \%$ de todas as pastagens cultivadas (Macedo, 1995). Soares Filho (1994) mencionou que esse cultivar adapta-se a condições de até 3.000 metros de altitude, precipitação pluvial anual ao redor de $700 \mathrm{~mm}$ e cerca de 5 meses de seca no inverno. No entanto, não suporta solos encharcados. É recomendado para áreas de média a boa fertilidade, embora tolere acidez no solo.

A temperatura ótima para seu desenvolvimento está entre 30 e $35^{\circ} \mathrm{C}$, sendo a mínima de $15^{\circ} \mathrm{C}$, embora tolere bem geadas (Skerman \& Riveiros, 1992). Apresenta reduzida tolerância ao sombreamento, desenvolvendo-se abundantemente a sol pleno. O cultivar Marandu, em especial, suporta bem o fogo (Ghisi \& Pedreira, 1987).

\subsubsection{Potencial produtivo}

O capim-Marandu apresenta elevado potencial de produção de massa verde, sendo muito usado na alimentação de ruminantes (Soares Filho, 1994). Apesar de tolerante a condições adversas, é extremamente responsivo a adubações, podendo ser encontradas produções bastante elevadas de até 36 toneladas de massa seca por hectare por ano segundo relatos de Ghisi \& Pedreira (1987). 


\subsubsection{Local do experimento}

\subsubsection{Localização geográfica}

O local de condução do experimento foi a Unidade Experimental de Plantas Forrageiras (UEPF), área coordenada pelo Grupo de Estudos de Plantas Forrageiras (GEPF) do Departamento de Zootecnia, da Escola Superior de Agricultura "Luiz de Queiroz", pertencente à Universidade de São Paulo (Figura 1).

A referida área está situada no município de Piracicaba, SP, sob as coordenadas geográficas aproximadas de $22^{\circ} 42^{\prime}$ de latitude sul, 47³8' de longitude oeste, e 546 metros de altitude (Ometo, 1989).

\subsubsection{Solo da área experimental}

O solo da área experimental é classificado como Nitossolo Vermelho eutroférrico, com horizonte A moderado e textura variando de argilosa a muito argilosa (EMBRAPA, 1999). Antes do estabelecimento dos pastos, foram realizadas amostragens para fins de avaliação de fertilidade do solo em todas as unidades experimentais. Os resultados podem ser verificados na Tabela 1.

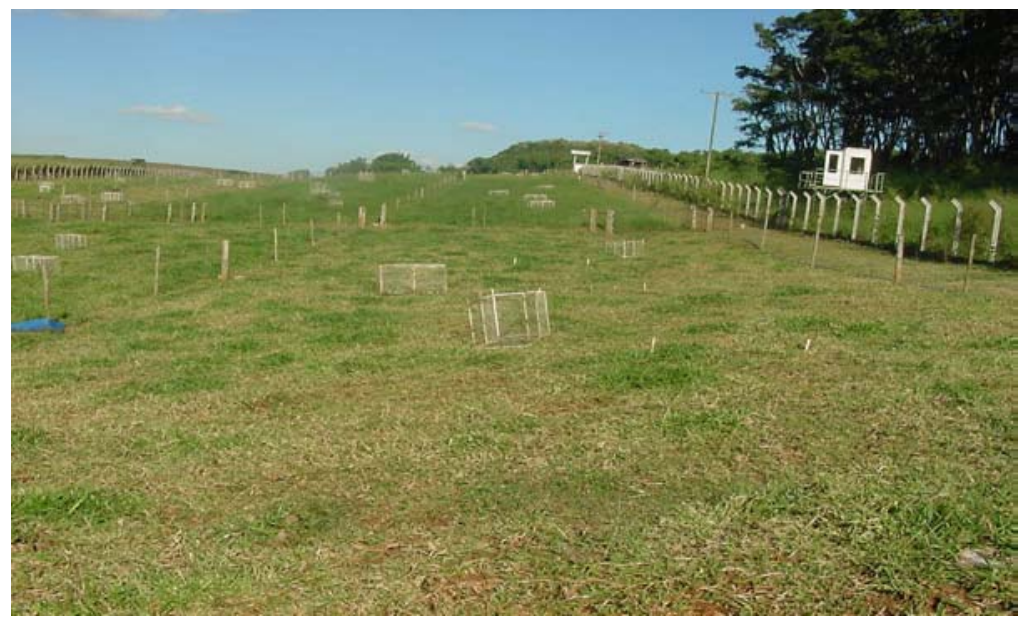

Figura 1 - Vista geral da área experimental. 
Tabela 1. Resultados da análise química de terra da área experimental.

\begin{tabular}{|c|c|c|c|c|c|c|c|c|c|c|c|}
\hline \multicolumn{2}{|c|}{ Parcela } & $\begin{array}{c}\mathrm{pH} \\
\mathrm{CaCl}_{2}\end{array}$ & $\begin{array}{l}\text { M.O. } \\
\text { d.dm }\end{array}$ & $\begin{array}{c}\mathrm{P} \\
\text { mg.dm }\end{array}$ & \multicolumn{6}{|c|}{$\mathrm{mmol}_{\mathrm{c} \cdot} \cdot \mathrm{dm}^{-3}$} & $\begin{array}{l}\mathrm{V} \\
\%\end{array}$ \\
\hline \multirow{4}{*}{ 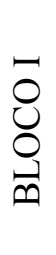 } & 10 & 5,6 & 44 & 64 & 73 & 22 & 11,4 & 29 & 106,4 & 135,4 & 79 \\
\hline & 20 & 5,9 & 48 & 52 & 60 & 19 & 7,1 & 28 & 86,1 & 114,1 & 75 \\
\hline & 30 & 5,9 & 44 & 59 & 69 & 23 & 6,8 & 28 & 98,8 & 126,8 & 78 \\
\hline & 40 & 6,0 & 44 & 47 & 74 & 26 & 6,2 & 24 & 106,2 & 130,2 & 82 \\
\hline \multirow{4}{*}{ 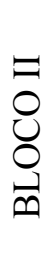 } & 10 & 5,7 & 44 & 58 & 56 & 19 & 6,5 & 33 & 81,5 & 114,5 & 71 \\
\hline & 20 & 5,8 & 46 & 51 & 59 & 18 & 7,8 & 33 & 84,8 & 117,8 & 72 \\
\hline & 30 & 5,6 & 40 & 51 & 59 & 19 & 8,6 & 31 & 86,6 & 117,6 & 74 \\
\hline & 40 & 5,7 & 40 & 58 & 49 & 18 & 7,4 & 29 & 74,4 & 103,4 & 72 \\
\hline \multirow{4}{*}{\begin{tabular}{l}
$\Xi$ \\
0 \\
0 \\
0 \\
\hdashline \\
\end{tabular}} & 10 & 5,6 & 41 & 61 & 88 & 20 & 5,9 & 36 & 113,9 & 149,9 & 76 \\
\hline & 20 & 5,5 & 43 & 56 & 72 & 16 & 5,6 & 34 & 93,6 & 127,6 & 73 \\
\hline & 30 & 5,5 & 40 & 80 & 63 & 19 & 7,4 & 36 & 89,4 & 125,4 & 71 \\
\hline & 40 & 5,5 & 41 & 82 & 81 & 20 & 5,7 & 36 & 106,7 & 142,7 & 75 \\
\hline \multirow{4}{*}{$\begin{array}{l}z \\
0 \\
0 \\
0 \\
\\
\end{array}$} & 10 & 5,2 & 35 & 89 & 91 & 14 & 5,9 & 45 & 110,9 & 155,9 & 71 \\
\hline & 20 & 5,2 & 37 & 84 & 111 & 17 & 5,2 & 47 & 133,2 & 180,2 & 74 \\
\hline & 30 & 5,0 & 38 & 80 & 86 & 11 & 2,5 & 55 & 99,5 & 154,5 & 64 \\
\hline & 40 & 5,2 & 38 & 96 & 93 & 15 & 3,5 & 50 & 111,5 & 161,5 & 69 \\
\hline
\end{tabular}

De acordo com RAIJ et al. (1996), os resultados encontrados demonstram a elevada fertilidade da área experimental, justificando a não necessidade da adoção de práticas como calagens e adubações potássicas e/ou fosfatadas para correção do solo no momento da semeadura e estabelecimento da planta forrageira. 


\subsubsection{Clima}

\subsubsection{Classificação}

De acordo com o sistema Köppen, o clima na região de Piracicaba é caracterizado como mesotérmico úmido, subtropical de inverno seco, classificado como Cwa, com temperaturas médias inferiores a $18^{\circ} \mathrm{C}$ no mês mais frio e superiores a $22^{\circ} \mathrm{C}$ na época mais quente (BRASIL, 1960).

\subsubsection{Dados climáticos do período de avaliação}

Os dados climáticos referentes ao período experimental foram coletados no posto meteorológico do Departamento de Ciências Exatas da Escola Superior de Agricultura "Luiz de Queiroz", Universidade de São Paulo, situado cerca de 500 metros da área experimental (Figura 2).

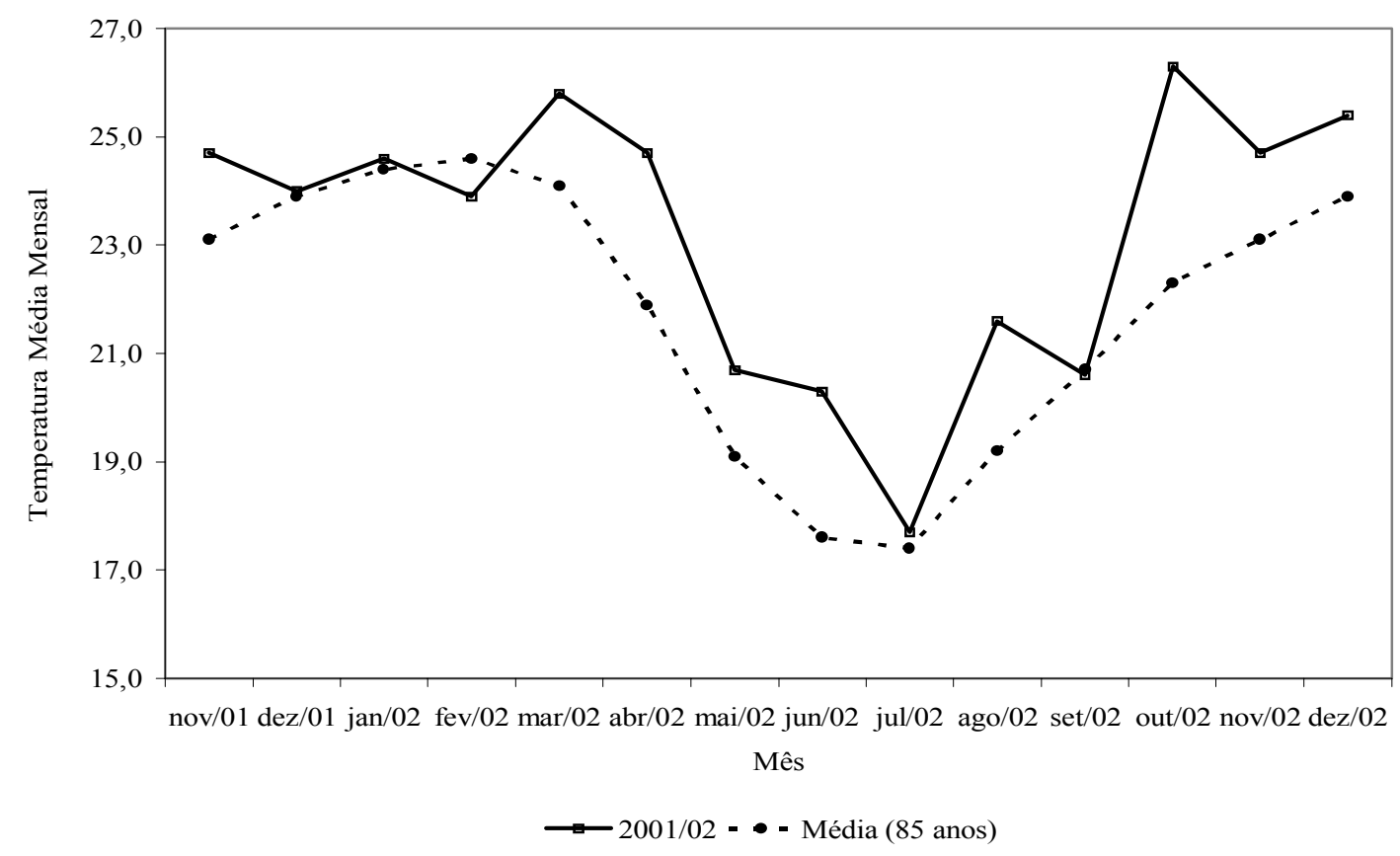

Figura 2 - Distribuição da temperatura média durante o período experimental comparada com a média dos últimos 85 anos (1917-2002). 
A Figura 3 apresenta os resultados do balanço hídrico decendial, valores determinados considerando-se uma CAD (capacidade de armazenamento de água) de $50 \mathrm{~mm}$, assim como, as adubações realizadas entre os meses de novembro de 2001 e dezembro de 2002.

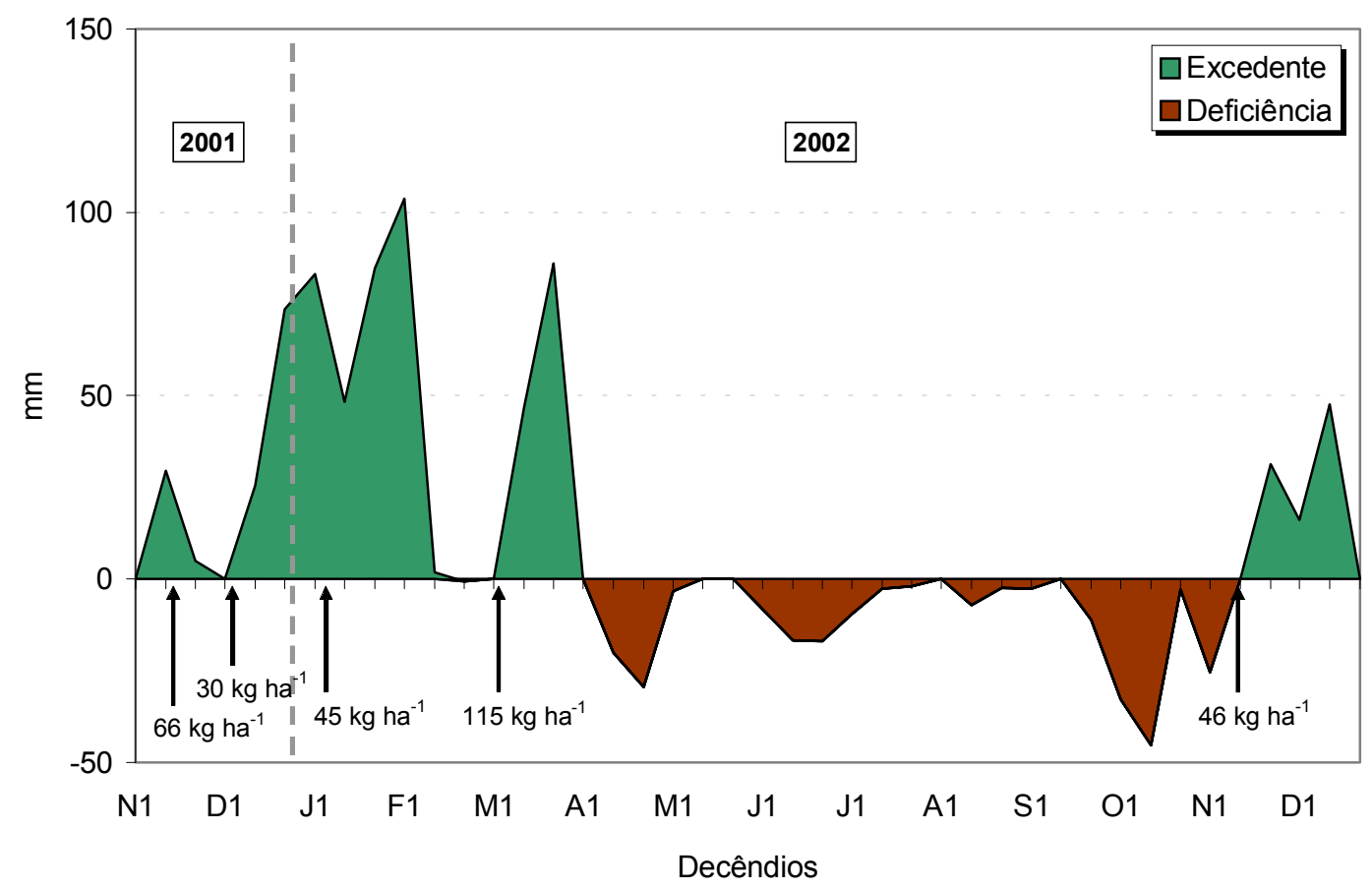

Figura 3 - Balanço hídrico da área experimental de novembro de 2001 a dezembro de 2002 e adubações nitrogenadas realizadas.

\subsubsection{Animais}

Foram utilizados bovinos de corte das raças Nelore e Canchim oriundos do plantel do Departamento de Zootecnia da USP/ESALQ (Figura 4). Em virtude da reduzida área experimental, optou-se por animais jovens e relativamente leves. Foram selecionadas 30 novilhas desmamadas da raça Nelore, com peso vivo médio inicial de $215 \mathrm{~kg}$, destinadas aos blocos I e III, e outras 30 novilhas desmamadas da raça Canchim, com peso vivo médio inicial 
de $250 \mathrm{~kg}$, destinadas aos blocos II e IV. Os animais foram pareados em função do peso vivo e alocados (dois a dois) às unidades experimentais que apresentavam condições de início de pastejo, para a manutenção das alturas do dossel forrageiro inerentes a cada tratamento a partir de 26 de setembro de 2001. Com o transcorrer do experimento, o peso dos animais se tornou muito elevado (peso médio de $310 \mathrm{~kg}$ ), razão pela qual foram substituídos por um novo lote de animais que passou a ser utilizado a partir de 18 de junho. Esse lote, composto de 31 animais da raça Nelore e 26 da raça Canchim, apresentava peso vivo médio de $160 \mathrm{~kg}$ e foi utilizado até o término do experimento em 18 de janeiro de 2003.

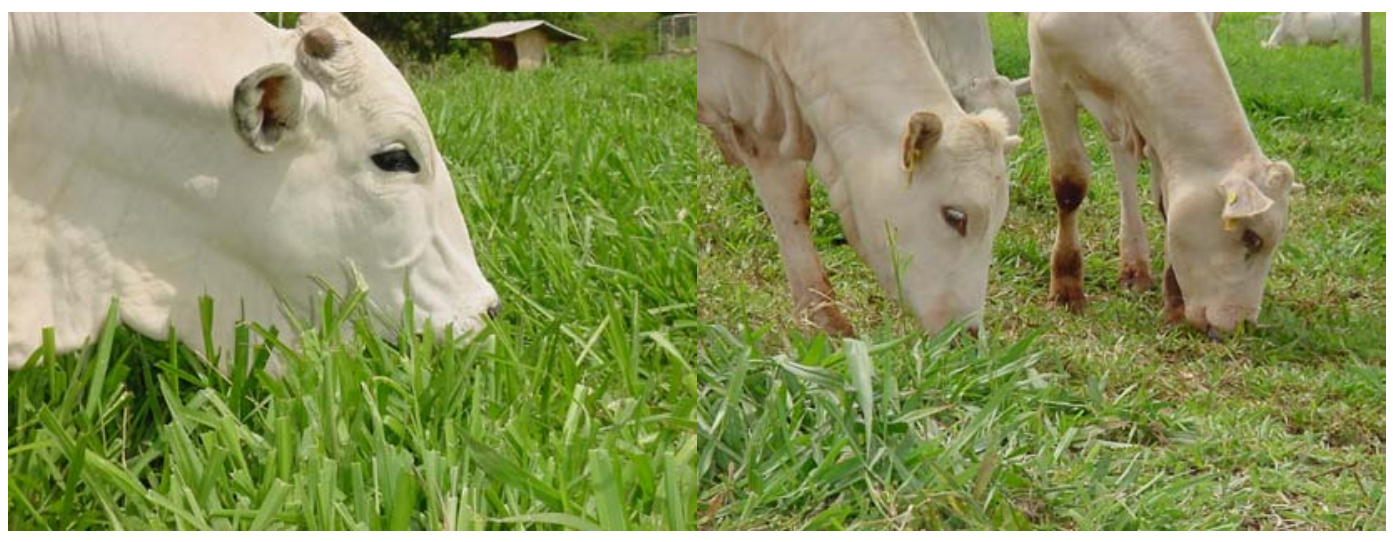

Figura 4 - Animais utilizados para as avaliações de comportamento ingestivo.

\subsection{Métodos}

\subsubsection{Delineamento experimental e tratamentos}

O delineamento experimental adotado para condução do experimento foi o de blocos completos casualizados com quatro repetições. Os tratamentos corresponderam a quatro alturas de dossel forrageiro (10, 20, $30 \mathrm{e}$ $40 \mathrm{~cm}$ ) mantidas constante ("steady state") através da adição ou retirada de animais das unidades experimentais. Portanto, durante todo o período 
experimental, adotou-se a técnica de lotação contínua com taxa de lotação variável. A área experimental possui um total de 16 unidades experimentais com cerca de $1.200 \mathrm{~m}^{2}$ cada, perfazendo um total aproximado de 2 hectares (Figura 5).

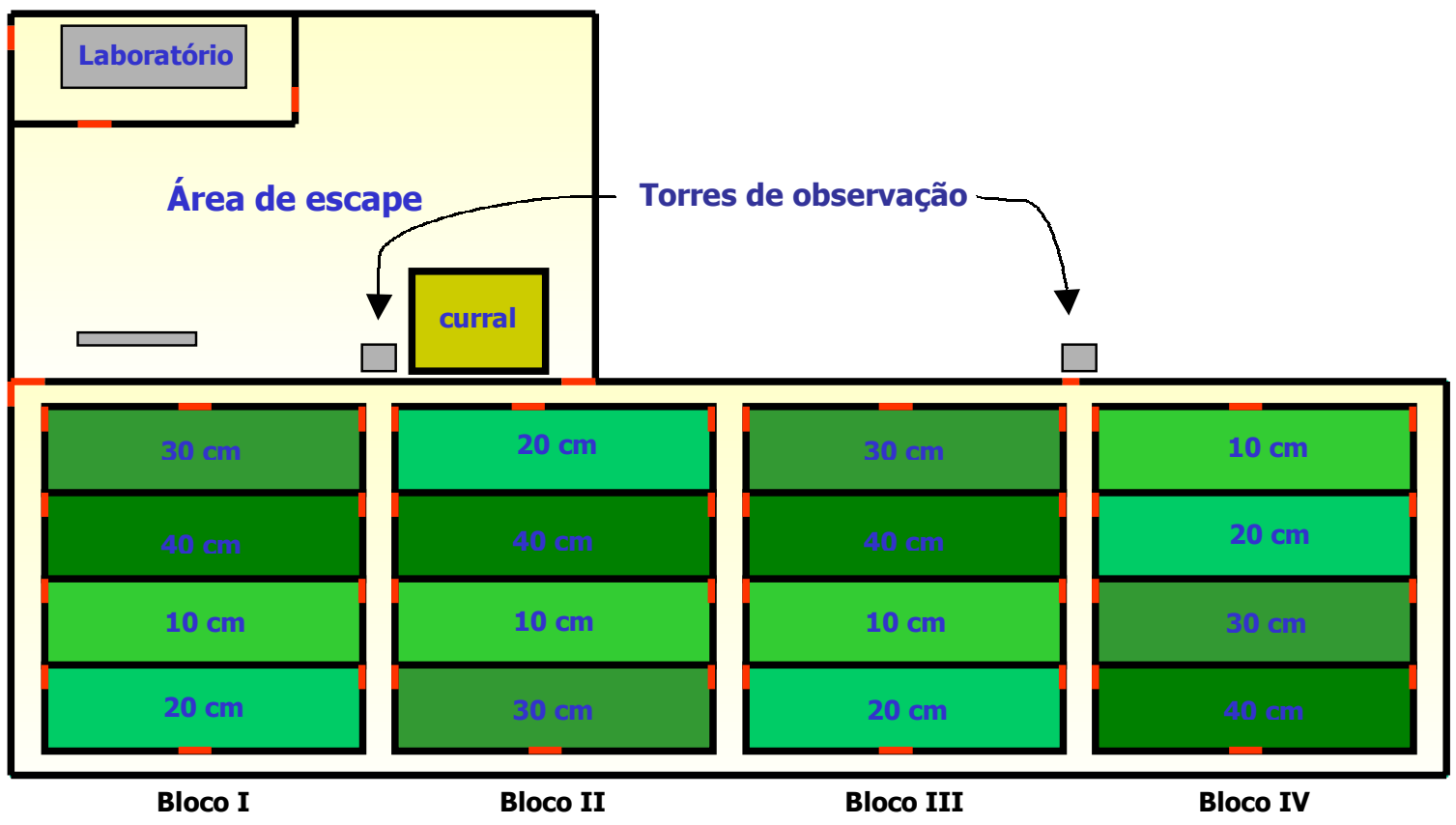

Figura 5 - Croqui da área experimental do GEPF.

\subsubsection{Instalação das condições experimentais}

\subsubsection{Semeadura}

A semeadura do capim-Marandu teve início em 30 de setembro de 2000. Foram aplicados $7 \mathrm{~kg}$ de sementes puras viáveis por hectare através do uso de semeadora-adubadora de 4 linhas, com sistema de distribuição gravimétrico de fluxo contínuo, adaptada para o sistema de plantio direto. Devido ao grande número de falhas, foram necessárias intervenções e adotada 
a repicagem e plantio de mudas do mesmo capim em dezembro de 2000, objetivando um maior fechamento da área.

Em janeiro de 2001 foram realizadas duas roçadas severas nos pastos a um curto intervalo de tempo (12 dias). Sua severidade e o período de deficiência hídrica moderada posterior a elas promoveu a morte de um grande número de touceiras, prejudicando o estabelecimento da pastagem. Tentou-se, a princípio, promover o restabelecimento apenas nos pontos mais prejudicados por meio de semeadura a lanço no dia 11 de abril de 2001. No entanto, o efetivo estabelecimento da área só foi alcançado após a semeadura em área total, com $10 \mathrm{~kg}$ de sementes puras viáveis por hectare, através do uso de semeadora-adubadora de 20 linhas com sistema de distribuição gravimétrico de fluxo contínuo, específica para o sistema de plantio direto, no dia 21 de maio de 2001.

\subsubsection{Controle de plantas daninhas}

A área experimental era formada anteriormente por pastagens de gênero Cynodon spp.. Para promover seu controle e permitir que a semeadura pudesse ser realizada, foram efetuadas aplicações de herbicida dessecante à base de Glyphosate, na dosagem de $2,4 \mathrm{~kg}$ de ingrediente ativo (i.a.) por hectare.

Após a semeadura, as plantas invasoras que causaram os maiores problemas ao estabelecimento dos pastos foram os capins Tifton-85, Florakirk e Coastcross (Cynodon spp.), o capim pé-de-galinha (Eleusine indica L.), o capim rabo de raposa (Setaria geniculata (Lem.) Beauv.), o caruru (Amaranthus sp.), a beldroega (Portulaca oleraceae L.), e a corda-de-viola (Ipomoea sp.). O controle dessas plantas daninhas foi efetuado durante todo o período de estabelecimento das pastagens através da ação física pelo arranquio e capinas freqüentes, e pela ação química com o uso do herbicida Diclorofenoxiacético em área total, na dosagem de $2,4 \mathrm{~kg}$ de i.a. por hectare, ou de forma dirigida 
sobre as plantas invasoras através do uso de herbicida Glyphosate, na dosagem de 2,4 kg de i.a. por hectare. A partir de maio de 2001, a ação física de controle recebeu o reforço do pastejo seletivo efetuado por eqüinos e muares do Departamento de Zootecnia da USP/ESALQ, principalmente no combate à maior invasora, o Cynodon spp..

\subsubsection{Fertilização e tratos culturais}

Dada a elevada fertilidade natural do solo da área experimental (Tabela 1) nenhum tipo de adubação de correção foi efetuada (item 1.3). Após a semeadura e estabelecimento, foram realizadas três adubações nitrogenadas antes do início do período de amostragens. A primeira foi realizada em 10 de janeiro de 2001, com a aplicação de uréia na dosagem correspondente a 67,5 kg por hectare de nitrogênio. A segunda foi realizada em 21 de janeiro de 2001, com a aplicação de sulfato de amônio em dosagem correspondente a 50 kg por hectare de nitrogênio, e a terceira, em 1 de outubro de 2001, com a aplicação de sulfato de amônio em dosagem correspondente a $50 \mathrm{~kg}$ por hectare de nitrogênio.

Imediatamente antes das adubações de janeiro de 2001, foram efetuadas roçadas com o objetivo de promover a elevação do número de touceiras na área pelo aumento do número de perfilhos. Nessa ocasião, as duas roçadas foram realizadas o mais próximo do solo possível, a cerca de 3 a 5 centímetros. Em março de 2001 uma nova roçada rente ao solo foi realizada. No final do mês de agosto de 2001 foi realizada uma roçada menos severa, com o intuito de uniformizar as pastagens em todas as parcelas (corte de uniformização). Essa roçada foi realizada a uma altura de 8 centímetros da superfície do solo, pouco abaixo da menor altura de tratamento $(10 \mathrm{~cm})$ a ser avaliada. 


\subsubsection{Monitoramento das condições experimentais}

\subsubsection{Alturas dos tratamentos}

A partir da roçada de 28 e 29 de agosto, foi iniciado o monitoramento das condições de altura do dossel forrageiro nas parcelas experimentais. Esse controle era realizado através de medições a intervalos de 3 e 4 dias (2 vezes por semana), em 20 pontos em cada unidade experimental, com o uso de transparência e régua graduada em centímetros (Fagundes, 1999). Animais eram adicionados quando a altura do dossel forrageiro apresentava-se acima do determinado para o tratamento, e retirados quando essa ficava abaixo do esperado. A princípio planejou-se uma variação da ordem de 10 a 15\% na altura média dos tratamentos, mas, em determinados momentos, como ocorreu em janeiro de 2002, a necessidade de permanência dos animais por um maior período de tempo para que avaliações concomitantes de comportamento animal em experimento conjunto fossem realizadas, causou decréscimo mais drástico da altura e massa de forragem dos tratamentos de 30 e 40 centímetros (Figuras 6 e 7$)$.

\subsubsection{Fertilização e tratos culturais}

Para assegurar a permanência dos animais pelo maior período de tempo possível nas parcelas experimentais através da produção e oferta abundantes de forragem, foram realizadas adubações estratégicas com nitrogênio e potássio. A Tabela 2 apresenta as datas e as adubações realizadas no decorrer do período experimental. 


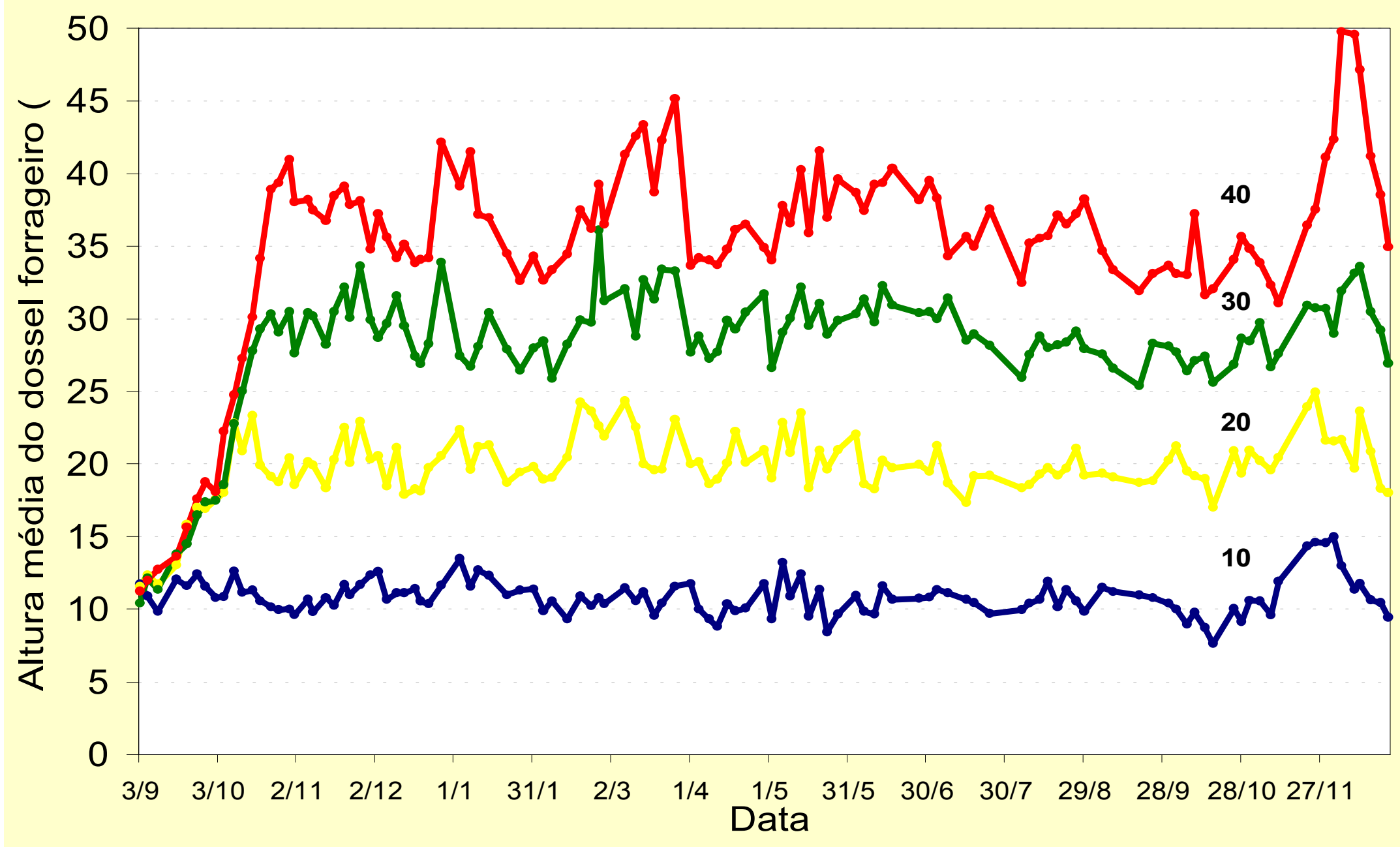

Figura 6. Valores médios das alturas dos tratamentos $(\mathrm{cm})$ ao longo do período experimental. Alturas dos tratamentos (cm): 10, 20, 30 e $40 \mathrm{~cm}$. 


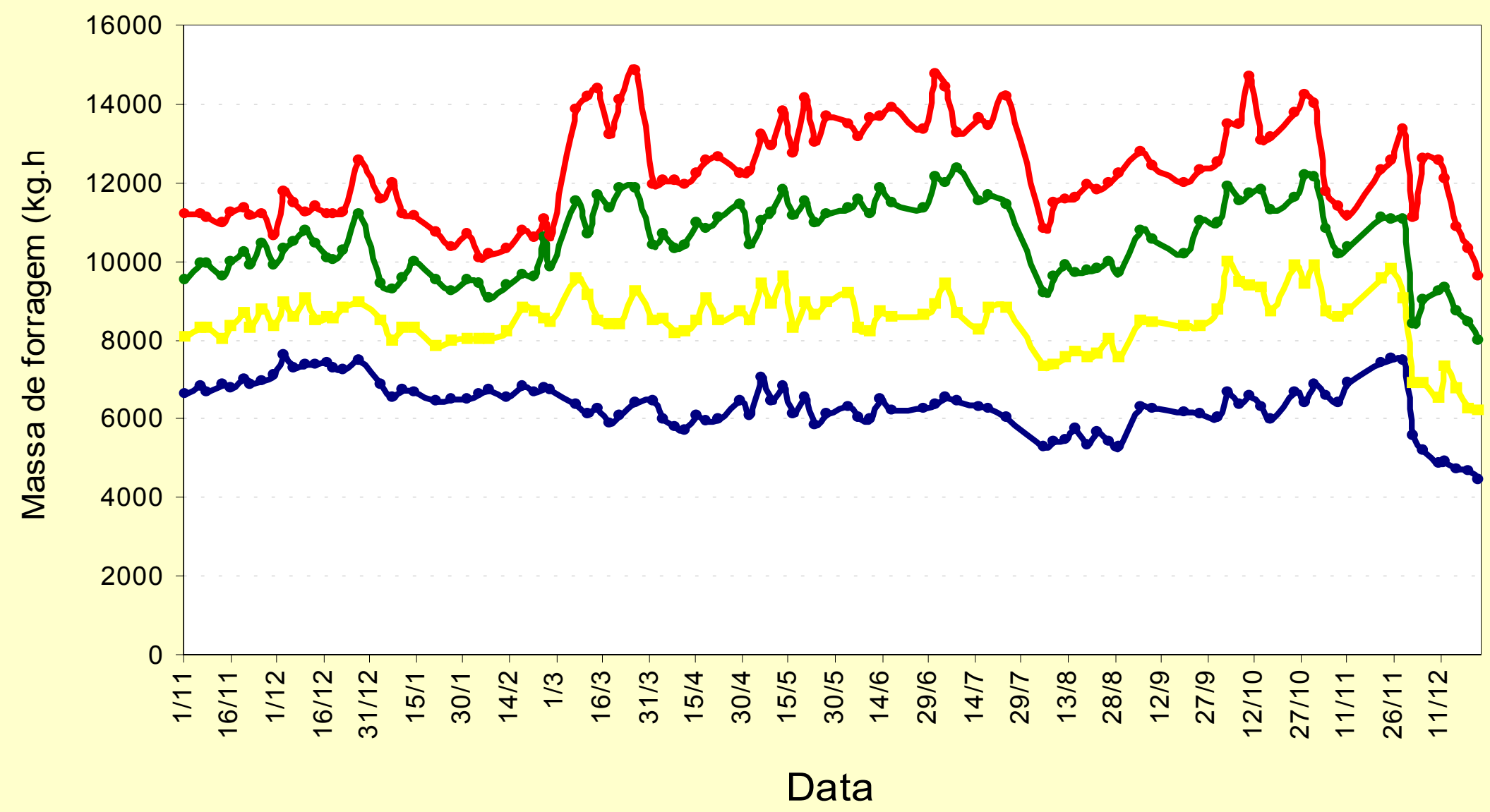

Figura 7. Valores médios das massas de forragem dos tratamentos $(\mathrm{cm})$ ao longo do período experimental. Alturas dos tratamentos (cm): 10, 20, 30 e $40 \mathrm{~cm}$. 
Tabela 2. Relação das adubações realizadas durante o período experimental.

\begin{tabular}{cccc}
\hline Data & $\begin{array}{c}\text { Quantidade de } \\
\text { nitrogênio aplicada }\end{array}$ & $\begin{array}{c}\text { Quantidade de } \\
\text { potássio aplicada }\end{array}$ & Fertilizante \\
\hline 07/11/01 & $66 \mathrm{~kg} \cdot \mathrm{ha}^{-1}$ de N & & Nitrato de amônio \\
01/12/01 & $30 \mathrm{~kg} \cdot \mathrm{ha}^{-1}$ de N & $20 \mathrm{~kg} \cdot \mathrm{ha}^{-1}$ de K$_{2} \mathrm{O}$ & 30.00 .20 \\
$10 / 01 / 02$ & $45 \mathrm{~kg} \cdot \mathrm{ha}^{-1}$ de N & $30 \mathrm{~kg} \cdot \mathrm{ha}^{-1}$ de K$_{2} \mathrm{O}$ & 30.00 .20 \\
$7 / 03 / 02$ & $115 \mathrm{~kg} \cdot \mathrm{ha}^{-1}$ de N & & Uréia \\
$30 / 10 / 02$ & $46 \mathrm{~kg} \cdot \mathrm{ha}^{-1}$ de N & & Uréia \\
Total & $302 \mathrm{~kg} \cdot \mathrm{ha}^{-1}$ de N & $50 \mathrm{~kg} \cdot \mathrm{ha}^{-1}{\text { de } \mathrm{K}_{2} \mathrm{O}}$ & \\
\hline
\end{tabular}

\subsubsection{Controle do peso vivo no período experimental}

Por ocasião do ajuste da taxa de lotação nas parcelas experimentais, tanto na entrada como na saída dos animais, era efetuada uma pesagem após jejum de alimento e água de 16 horas. Além da pesagem de ajuste de carga, todos os animais alocados para o experimento tiveram seus pesos em jejum coletados mensalmente para o acompanhamento do ganho de peso.

\subsubsection{O período experimental}

O período experimental teve início em 01 de novembro de 2001, após a estabilização das alturas dos pastos planejadas (Figura 6), e foi encerrado em 14 de janeiro de 2003. 


\subsubsection{Avaliações de campo}

\subsubsection{Estrutura do dossel forrageiro}

A avaliação da distribuição espacial dos componentes morfológicos do pasto foi realizada utilizando-se um aparelho chamado "ponto inclinado" (ou "inclined point quadrat") (Figura 8). O aparelho era estacionado em um local com a altura média de cada unidade experimental, no momento da amostragem, permitindo a descrição da distribuição vertical de componentes morfológicos do pasto à medida que sua haste graduada era introduzida através do dossel forrageiro e sua ponta tocava diferentes estruturas e tecidos vegetais (folha verde, folha senescente, folha morta, haste vegetativa, haste reprodutiva, material morto, haste de invasoras e folhas de invasoras) (LACA \& LEMAIRE, 2000). Cada estrutura tocada era identificada e a altura em que o toque ocorreu era marcada através de leitura da haste do aparelho graduada em centímetros. Os dados eram anotados em uma planilha estruturada para esta avaliação. Após cada toque, o componente tocado era cuidadosamente retirado da ponta da haste do aparelho para que se pudesse dar continuidade ao procedimento, introduzindo-se a haste no dossel forrageiro até que novo toque ocorresse. Esse procedimento era repetido até que a ponta da haste do aparelho tocasse o solo. Foi realizado um mínimo de 100 toques por unidade experimental (400 toques por tratamento), o que correspondeu a um número médio de oito a quinze estações de leitura por unidade experimental. Esta avaliação foi repetida mensalmente, sendo realizado um mínimo de 1600 toques por mês, ou seja, 22400 toques nos 14 meses estudados.

Os dados foram processados mensalmente de tal forma que todos os toques ocorridos no mesmo tratamento (100 toques/repetição e 4 repetições/tratamento, total de 400 toques) somassem $100 \%$ e os toques dados em cada estrutura vegetal em cada estrato eram sempre uma fração deste valor. O resultado, portanto, revelou a proporção (\%) de toques realizados em 
cada estrutura vegetal e em cada estrato do dossel forrageiro (estrato $=2 \mathrm{~cm}$ de altura).

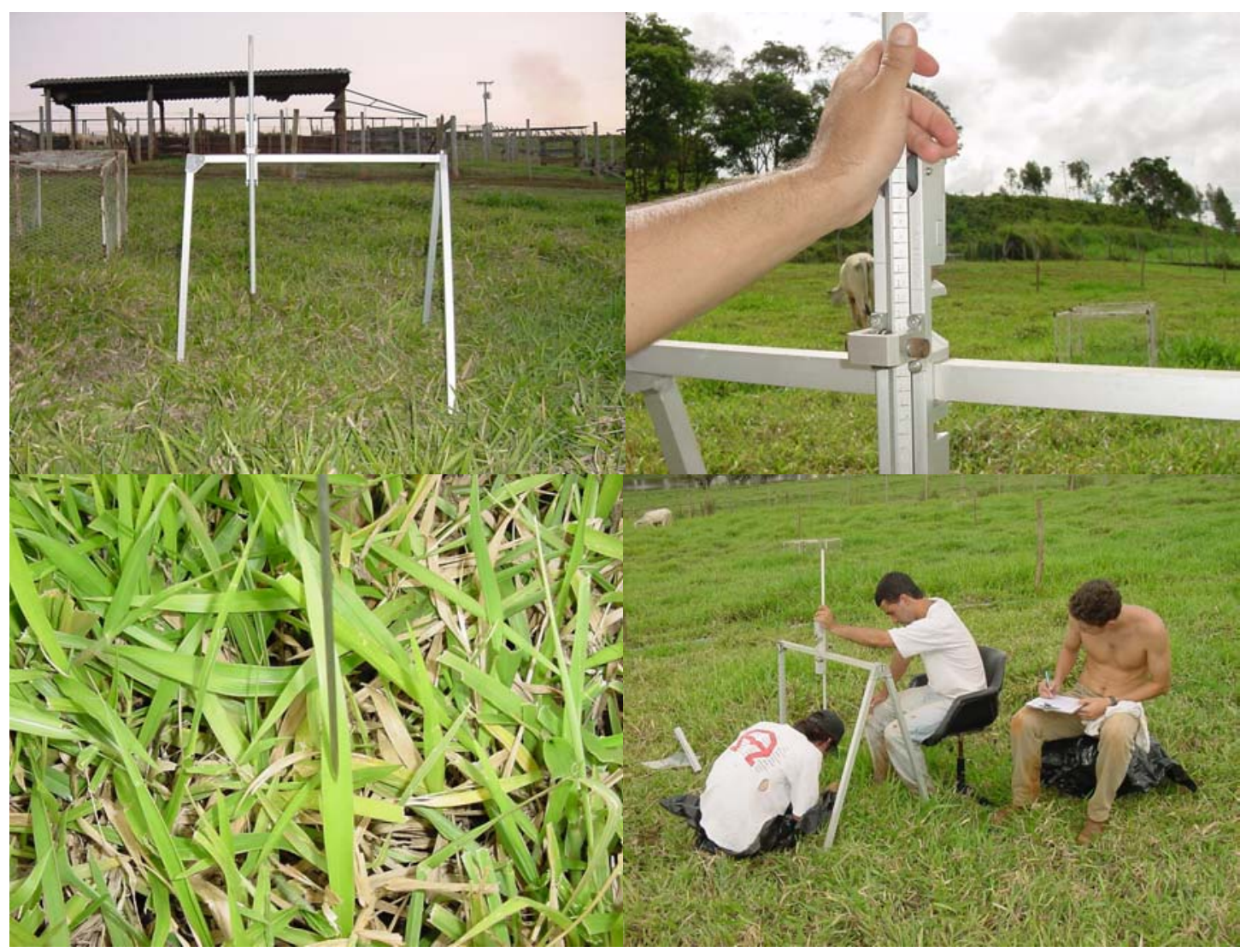

Figura 8 - Avaliação da estrutura do dossel forrageiro por meio do ponto inclinado.

\subsubsection{Massa de forragem e composição morfológica}

Uma vez ao mês eram feitos cortes utilizando-se um retângulo de 0,30 e $0,37 \mathrm{~m}$ (aproximadamente $0,11 \mathrm{~m}^{2}$ ). Para tanto eram escolhidos quatro pontos dentro de cada unidade experimental procurando-se, com o auxílio de régua e transparência (FAGUNDES, 1999), uma região que apresentasse a altura média do dossel forrageiro no dia da amostragem. Posteriormente, a forragem era cortada no nível do solo, sendo encaminhada para o laboratório 
onde eram geradas duas sub-amostras. Uma era seca em estufa de circulação forçada de ar a $65^{\circ} \mathrm{C}$ até massa constante e em seguida quantificada, fornecendo os valores de massa de forragem. A outra era submetida a um processo de separação manual no qual os componentes folha (lâmina foliar), haste (bainha foliar e haste), invasoras e material morto (incluía a parte morta das folhas senescentes) eram separados. Esses componentes eram secos em estufa de circulação forçada de ar a $65^{\circ} \mathrm{C}$ até massa constante, quantificados, gerando a composição morfológica da forragem colhida.

\subsubsection{Densidade volumétrica}

A distribuição espacial da densidade volumétrica dos componentes morfológicos do dossel forrageiro foi determinada utilizando-se duas avaliações. A primeira, de composição botânica e morfológica (Item 3.2.5.2.), forneceu a informação da massa de cada componente morfológico por área. A segunda, da distribuição espacial percentual dos componentes morfológicos do dossel forrageiro (Item 3.2.5.1.), forneceu a informação da quantidade total de toques realizada em um determinado componente, e desta quantos toques foram dados em cada estrato do dossel forrageiro. Em seguida, a massa total de um determinado componente morfológico do pasto foi distribuída da mesma forma como foram distribuídos os toques dados nesse mesmo componente ao longo do perfil vertical do dossel forrageiro (estratos). O cálculo da densidade volumétrica, por fim, foi feito dividindo-se a massa desses componentes pela altura do estrato que a continha, ajustando-se as unidades. 


\subsubsection{Comportamento ingestivo}

\subsection{Tempo de pastejo, ruminação e ócio}

As avaliações foram realizadas durante um período de vinte e quatro horas com observações e identificação das atividades dos animais a cada dez minutos, utilizando-se binóculos e cronômetros. Para as observações noturnas, holofotes foram utilizados para a visualização dos animais, valendo ressaltar que dias antes das observações os animais eram iluminados no período noturno para que se adaptassem à rotina de utilização dos mesmos. Para a diferenciação dos animais, um dos dois animais de cada unidade experimental foi marcado com tinta (spray automotivo) (Figura 9). Havia um total de oito animais por tratamento (considerando-se os 4 blocos), sendo que jamais o limite mínimo de quatro animais por tratamento foi ultrapassado, uma vez que em situações de crescimento lento dos pastos havia a impossibilidade de se utilizar todas as unidades experimentais. Dessa forma, o número mínimo de avaliações realizadas ao longo do período experimental foi restrito e igual a seis (janeiro, fevereiro, maio, julho, agosto e dezembro).

Para a realização das avaliações foram utilizadas oito pessoas (alunos de pós-graduação e estagiários alunos de graduação em engenharia agronômica da ESALQ) de forma escalonada, mantendo-se sempre os mesmos observadores por bloco. Ao final, as mensurações inerentes às atividades de pastejo relativas a cada animal eram somadas, identificando-se, dessa forma, o tempo gasto pelos animais em cada atividade assim como os períodos do dia em que as mesmas se concentravam. 


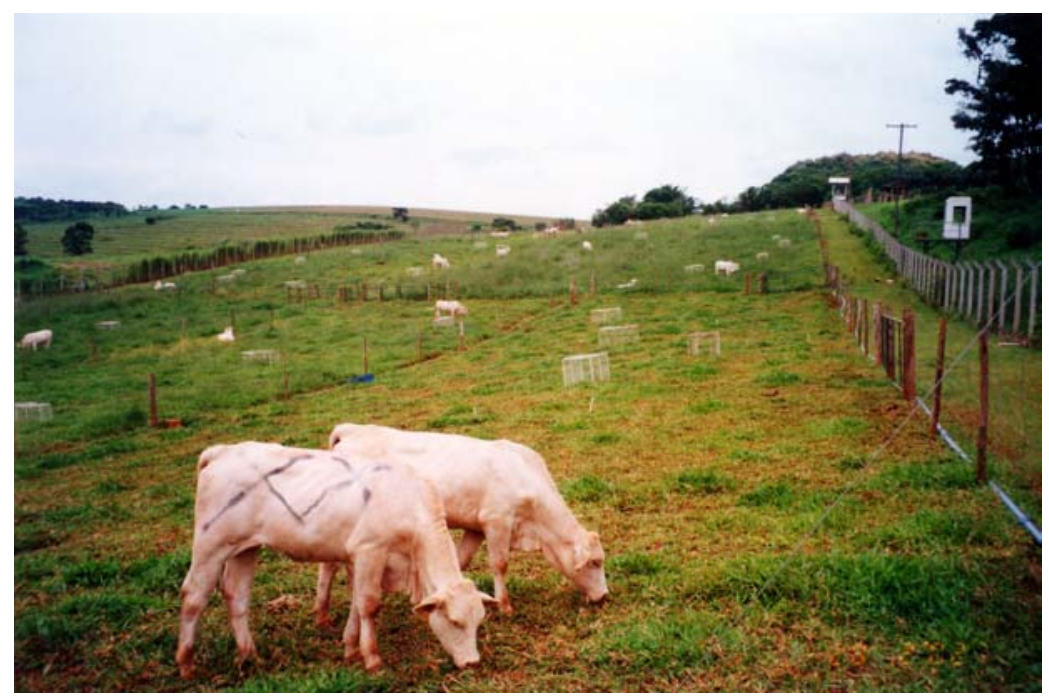

Figura 9 - Vista geral da área experimental em dia de comportamento ingestivo.

\subsection{Taxa de bocados}

No mesmo dia das observações de comportamento, filmagens foram feitas do alto de duas torres de observação (Figura 10) nos períodos de maior atividade de pastejo (início da manhã e final da tarde). Várias filmagens de cada animal foram realizadas (cerca de 10 minutos cada), intercaladas dentro do mesmo período, com o intuito de gerar-se o maior número possível de imagens de cada animal presente nas unidades experimentais, independentemente do tratamento.

De posse das filmagens, determinações da quantidade de tempo gasto para a execução de 20 bocados (HODGSON, 1982) foram realizadas da mesma forma como se fossem feitas diretamente no campo, com o benefício de se verificar e/ou realizar a mesma observação quantas vezes fosse julgado necessário, aumentando a acurácia do método. A taxa de bocados foi calculada como sendo o quociente entre 20 bocados e o tempo gasto para sua realização, sendo as médias dos tratamentos geradas a partir das observações de cada animal individualmente. 


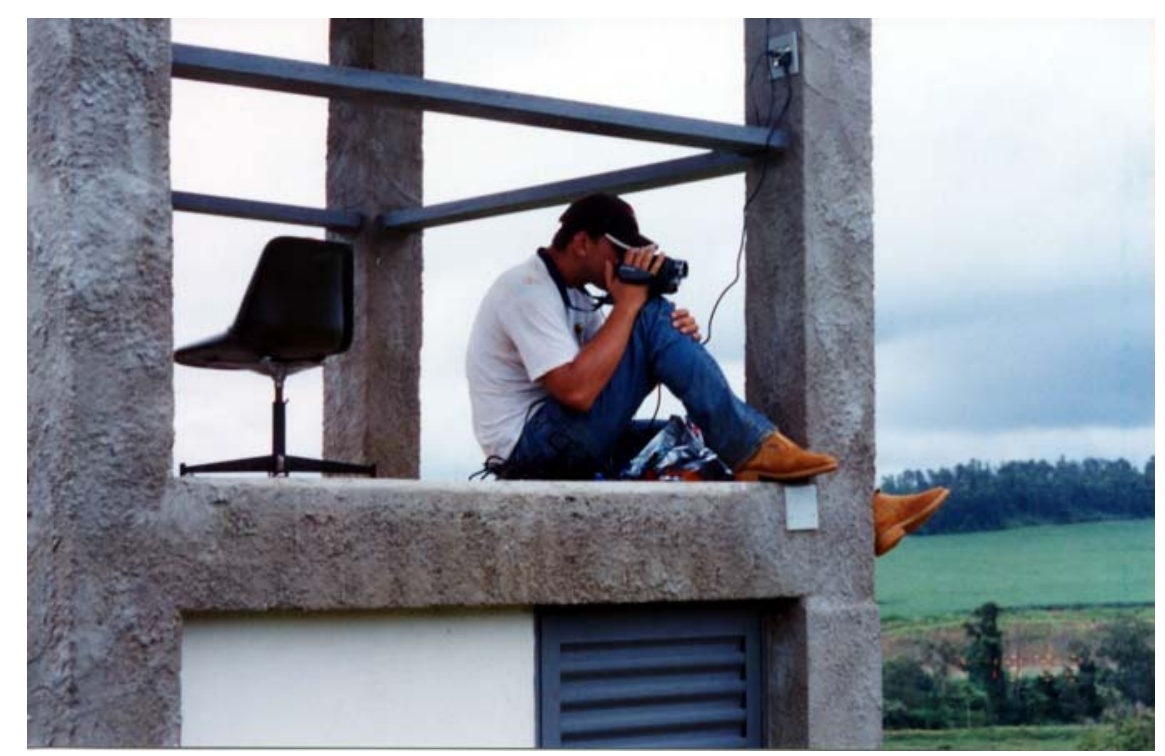

Figura 10 - Filmagem dos animais em dia de avaliação de comportamento ingestivo.

\subsection{Tamanho de bocado}

Para a avaliação de tamanho de bocado foram utilizadas fêmeas, também da raça Nelore, portadoras de cânulas esofagianas (Figura 11). Somente duas avaliações foram realizadas em virtude da possibilidade de inicio da utilização dos animais, a primeira teve início dia 31 de agosto de 2002 estendendo-se até o dia 5 de setembro, e a segunda teve início dia 10 de fevereiro de 2003 estendendo-se até o dia 14 do mesmo mês. Quatro animais foram utilizados em pares, de forma alternada, passando por todos os tratamentos de dois blocos na parte da manhã e no final da tarde, horários de maior atividade de pastejo, sendo que, a partir do momento em que os mesmos eram colocados em cada um dos tratamentos, iniciava-se a contagem do número de bocados por um período de 15 minutos. Ao final desse período as extrusas eram coletadas e, imediatamente, acondicionadas em sacos plásticos, quantificadas, sub-amostradas e encaminhadas para secagem em estufa de 
circulação de ar forçada a $65^{\circ} \mathrm{C}$, sendo posteriormente quantificadas. De posse desses valores foi calculada a massa média de forragem ingerida por bocado.

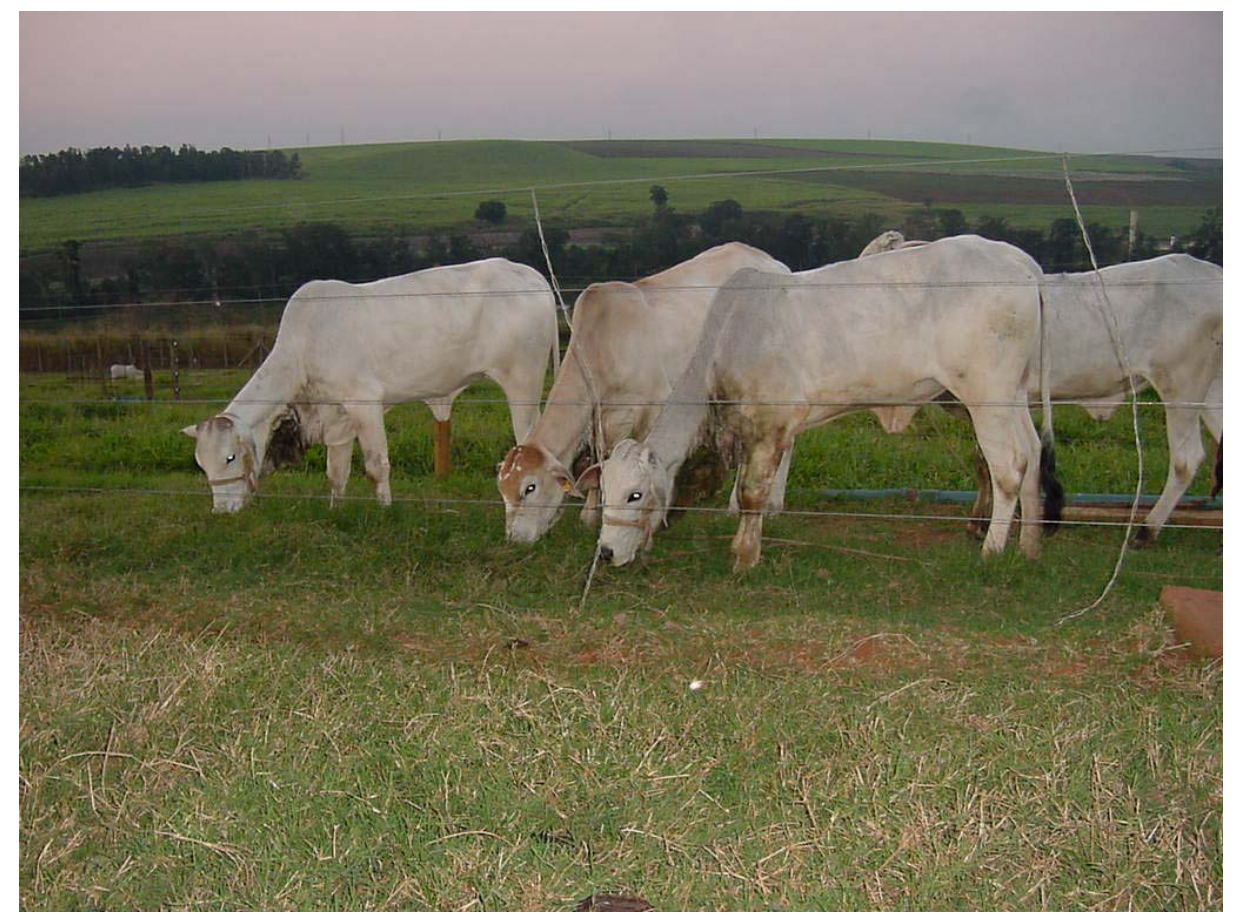

Figura 11- Animais portadores de cânulas esofagianas utilizados nas avaliações de tamanho de bocado.

\subsection{Consumo de forragem (n-alcanos)}

As avaliações de consumo de forragem foram realizadas por meio da técnica de marcadores externos, utilizando-se cápsulas de liberação controlada de n-alcanos (Captec-Nova Zelândia) (BURNS et al., 1994).

Duas estimativas de consumo foram realizadas, uma no dia 14 de janeiro de 2002, onde 27 novilhas com peso vivo médio de $280 \mathrm{~kg}$, após jejum (16 horas) e pesagem, receberam cápsulas de liberação controlada de nalcanos (Figura 12) e foram conduzidas a seus respectivos piquetes para que, após o período relativo à estabilização na liberação dos alcanos (oito dias), fossem realizadas as coletas de fezes. Havia a disponibilidade para a utilização 
de 32 cápsulas ( 4 tratamentos $\times 4$ repetições $\times 2$ animais/repetição) mas, devido à limitação anatômica de alguns animais relativamente ao tamanho das cápsulas disponíveis, apenas 27 puderam recebê-las. Após o oitavo dia de administração das cápsulas, se estendendo ao décimo segundo, foram iniciadas as coletas diárias de fezes sempre às sete horas da manhã. Logo após as coletas, as amostras eram congeladas, posteriormente secas em estufa de circulação de ar forçada a $65^{\circ} \mathrm{C}$ até massa constante e moídas, de forma a gerar uma amostra composta representativa por animal. A outra avaliação foi realizada dia 11 de dezembro de 2002, utilizando-se 30 novilhas com peso vivo médio de $240 \mathrm{~kg}$ e seguindo procedimento semelhante ao descrito para a primeira avaliação a única diferença sendo o período de coleta de fezes que, pela possibilidade de permanência dos animais por um período maior de tempo nas unidades experimentais nessa época do ano foi de sete ao invés de cinco dias.

Concomitantemente à coleta de fezes, simulações de pastejo foram realizadas (amostras com cerca de $300 \mathrm{~g}$ de massa fresca) e, em laboratório, duas sub-amostras foram separadas e levadas posteriormente à estufa, uma contendo os diferentes componentes morfológicos (haste e folha) e outra integral, sem separação. Depois de secas, as mesmas foram moídas e analisadas quanto ao perfil de alcanos. Os cálculos de cada fator de resposta para cada n-alcano foram realizados por referência ao padrão interno usando os procedimentos de UNTZ (1982). Posteriormente, foram calculadas as quantidades de cada n-alcano em um quilograma de matéria seca de forragem, de partes da planta e de fezes. A partir das taxas de liberação de alcanos das cápsulas, da concentração de alcanos nas fezes e do perfil observado nas plantas, obteve-se o consumo de forragem. 


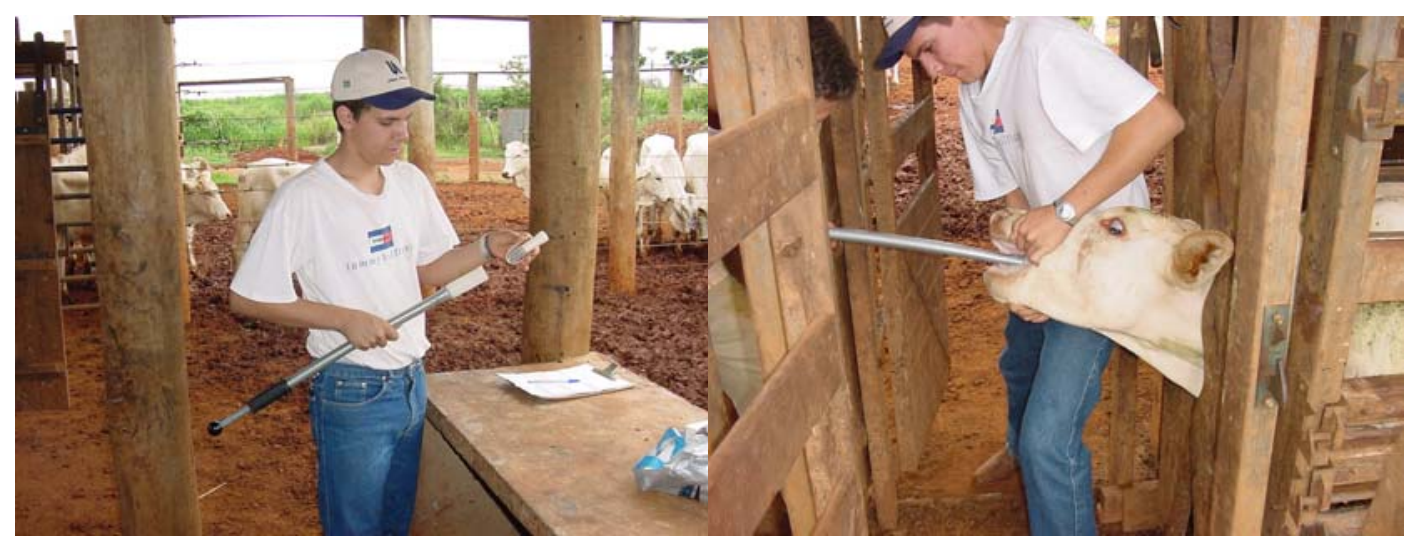

Figura 12 - Aplicação de cápsulas de n-alcanos.

\subsection{Análise estatística}

A análise estatística dos dados foi realizada por intermédio do pacote estatístico SAS (Statistical Analysis System), versão 8.0 para Windows, utilizando-se o PROC MIXED para a análise de variância, uma vez que foram realizadas medidas repetidas no tempo (SAS INSTITUTE, 2002). A comparação das médias foi feita através do "LSMEANS" com um nível de significância de $10 \%$. 


\section{RESULTADOS E DISCUSSÃO}

\subsection{Estrutura do dossel forrageiro}

Os dados referentes à estrutura do dossel forrageiro nos meses em que foram realizadas as avaliações de comportamento ingestivo são apresentados nas Figuras 13 a 18. De uma forma geral, o padrão de distribuição dos componentes morfológicos ${ }^{1}$ ao longo do perfil do dossel foi bastante consistente durante os meses em que a planta forrageira foi avaliada.

Nota-se que na base dos pastos predominava basicamente material morto e hastes e que no estrato superior correspondia às lâminas foliares. Outro fator relevante é que esse horizonte de folhas correspondeu, consistentemente, à proporção constante de $50 \%$ da parte superior do perfil vertical do dossel forrageiro, indicando aumento potencial do estrato pastejável (profundidade de pastejo) com o aumento da altura do dossel forrageiro, fato este com prováveis implicações sobre tamanho de bocado, taxa de bocado, tempo de pastejo e composição morfológica da forragem ingerida. Com relação à época do ano, houve um aumento nos valores de densidade volumétrica da forragem nos meses de maio, julho e agosto, principalmente nos tratamentos onde o pastejo era mais leniente $(30$ e $40 \mathrm{~cm}$ ) (Tabela 3), provavelmente pelo acúmulo de material morto na base do dossel e uma redução proporcional na

\footnotetext{
${ }^{1}$ MOLAN, L.K. (Escola Superior de Agricultura "Luiz de Queiroz", Piracicaba, SP). Estrutura do dossel e interceptação luminosa em pastos de Brachiaria brizantha cv. Marandu. (projeto de mestrado em andamento).
} 


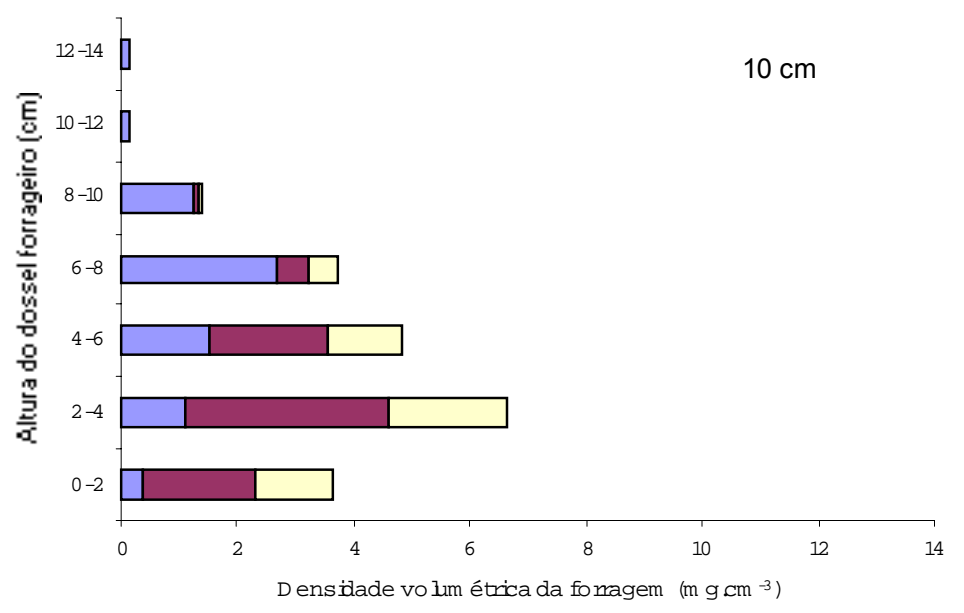

$\mathbf{Q}^{\mathrm{F} O \text { Tha }} \mathbf{Q}^{\text {Haste }} \mathbf{\square}^{\mathrm{M}}$ aterialM orto $\mathbf{\square}^{\text {Invasoras }}$

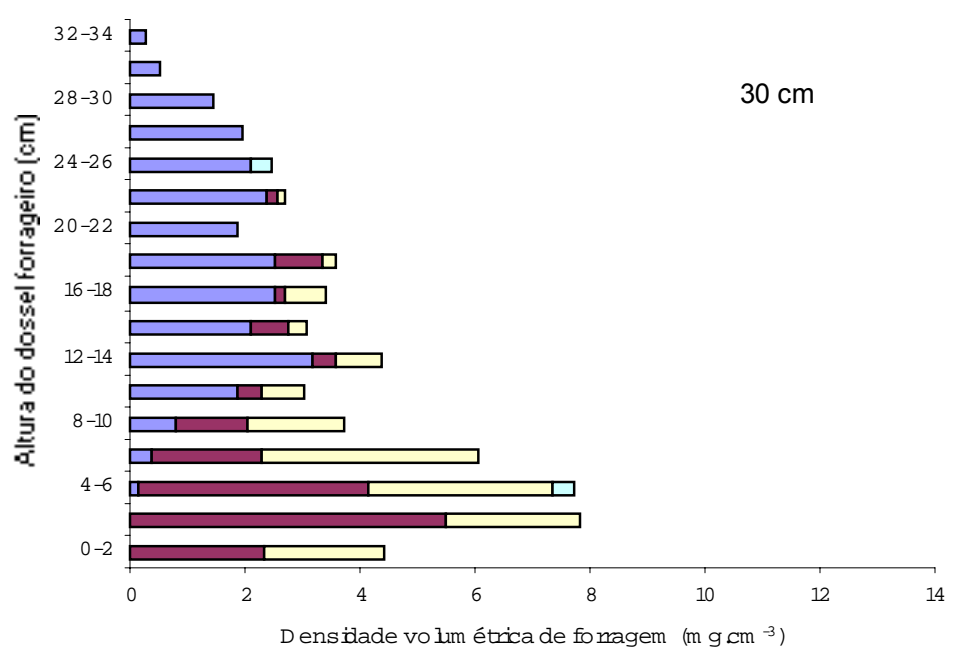

QFolha $\square$ Haste $\square^{M}$ aterialM orto $\square$ hivasoras

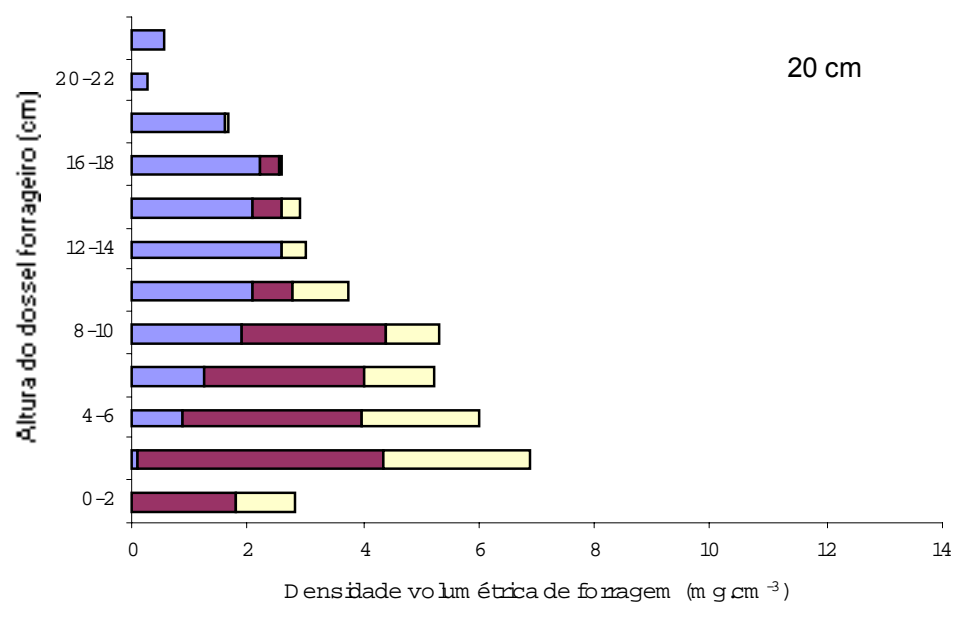

$\square$ Folha $\square$ Haste $\square$ M aterialM orto $\square$ hivasoras

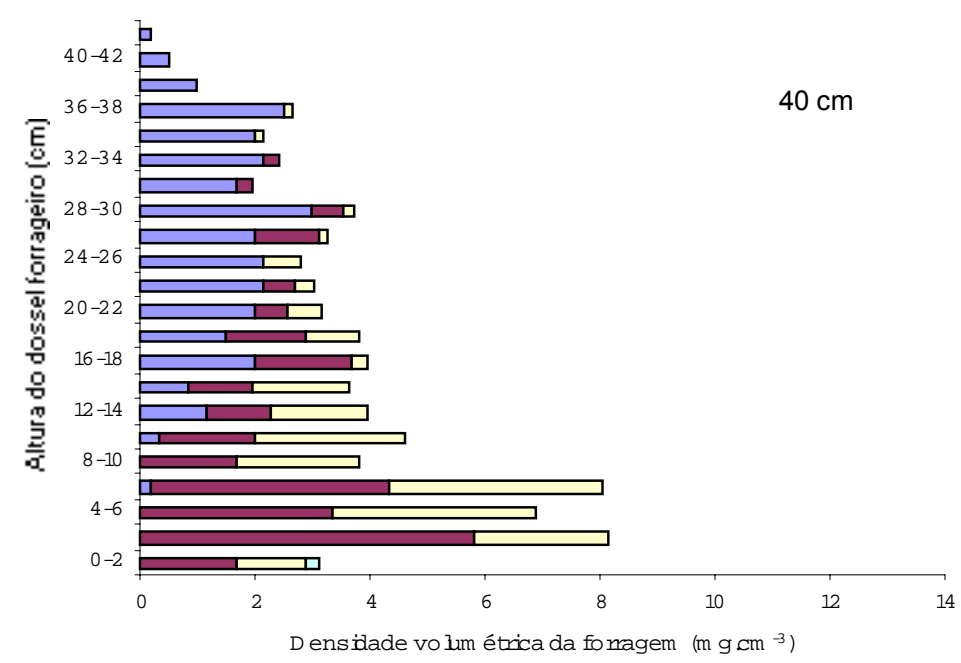

口Fo ha $\square^{\text {Haste }} \square^{M}$ aterialM orto $\square$ hvasoras

Figura 13 - Estrutura do dossel forrageiro de Brachiaria brizantha cv Marandu mantida em quatro alturas de pasto sob lotação contínua $(10,20,30$ e $40 \mathrm{~cm})$ durante o mês de janeiro de 2002. 

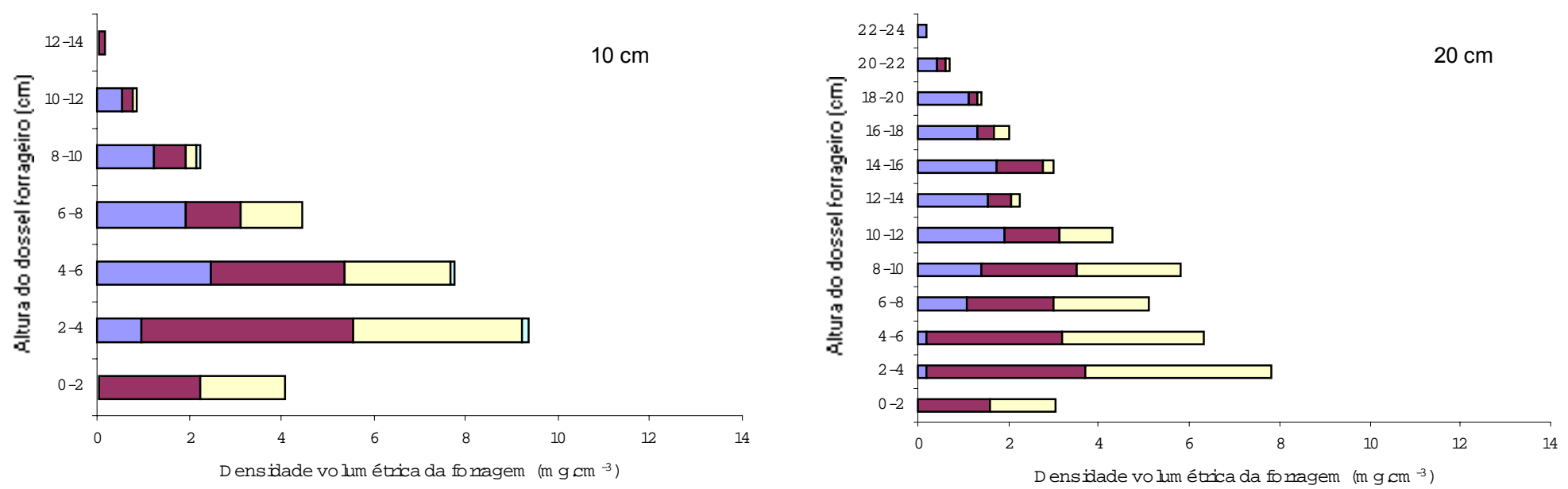

$\square^{\mathrm{F} \circ \text { ha }} \square^{\text {Haste }} \square^{\mathrm{M}}$ aterialM orto $\square$ Invaso ras

$\square^{F} \circ$ ha $\square$ Haste $\square^{M}$ aterialM orto $\square^{\text {hivasoras }}$
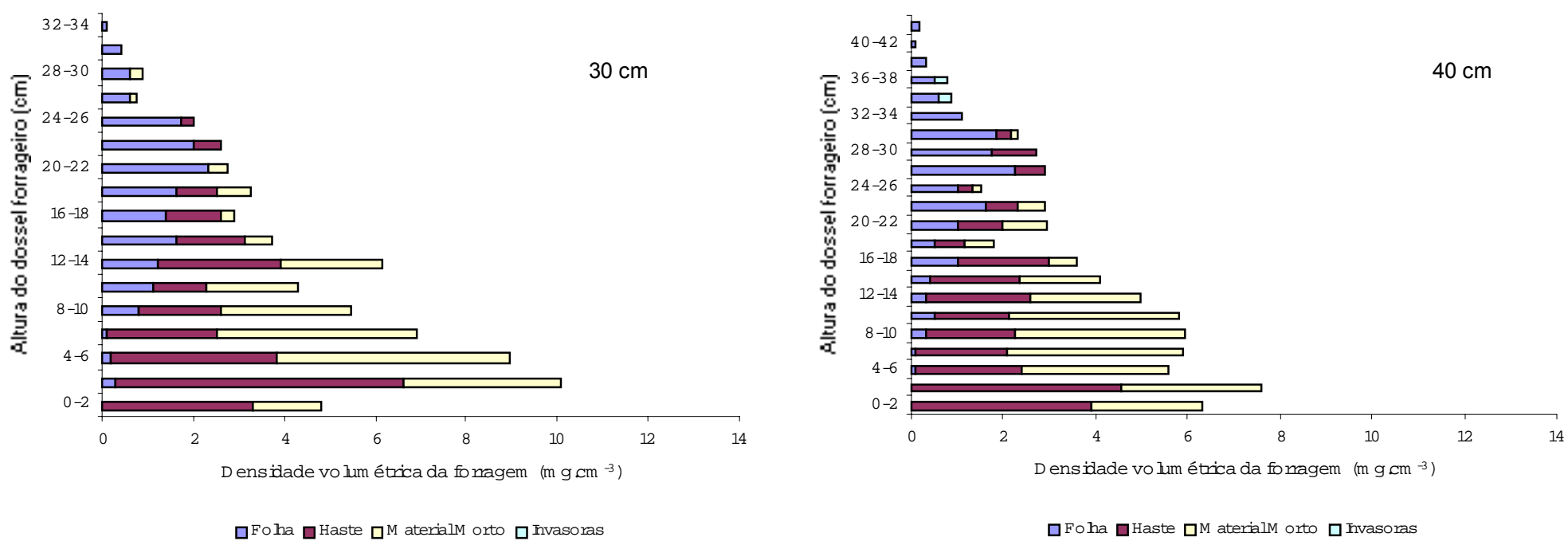

Figura 14 - Estrutura do dossel forrageiro de Brachiaria brizantha cv Marandu mantida em quatro alturas de pasto sob lotação contínua $(10,20,30$ e $40 \mathrm{~cm}$ ) durante o mês de fevereiro de 2002. 

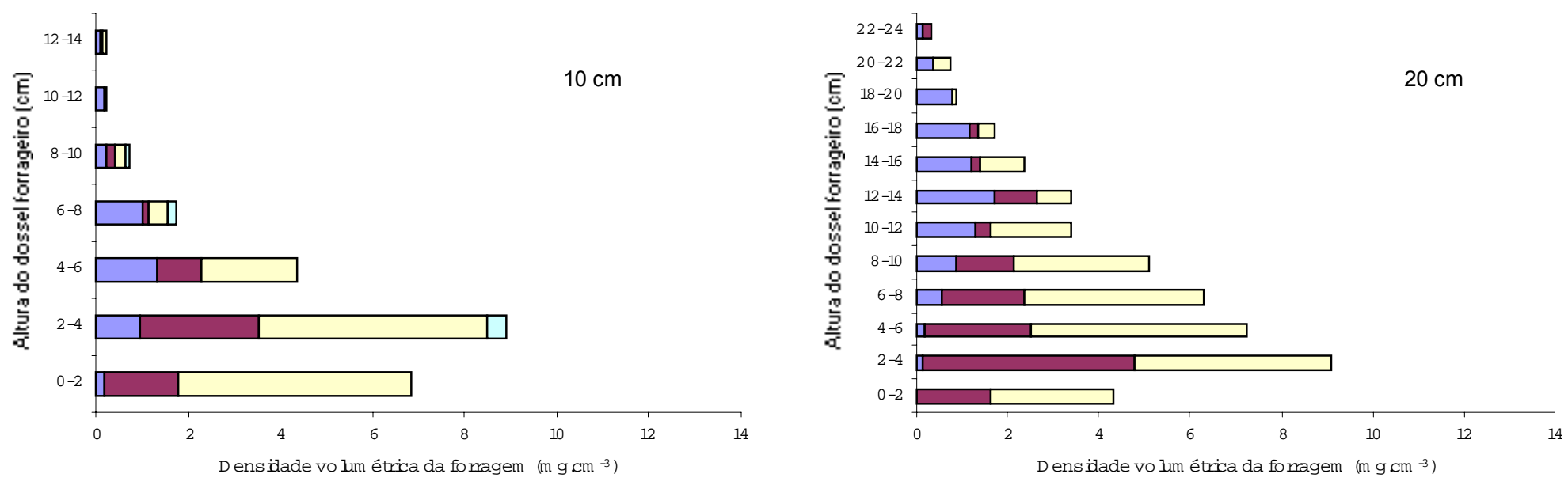

$\mathbf{Q}^{\mathrm{F} O \mathrm{ha}} \mathbf{\square}^{\text {Haste }} \mathbf{Q}^{\mathrm{M} \text { aterialM orto }} \mathbf{\square}^{\text {hvasoras }}$

$\mathbf{Q}^{\mathrm{F} O \mathrm{ha}} \mathbf{\square}^{\text {Haste }} \mathbf{Q}^{\mathrm{M}}$ aterialM orto $\mathbf{\square}^{\text {Invasoras }}$
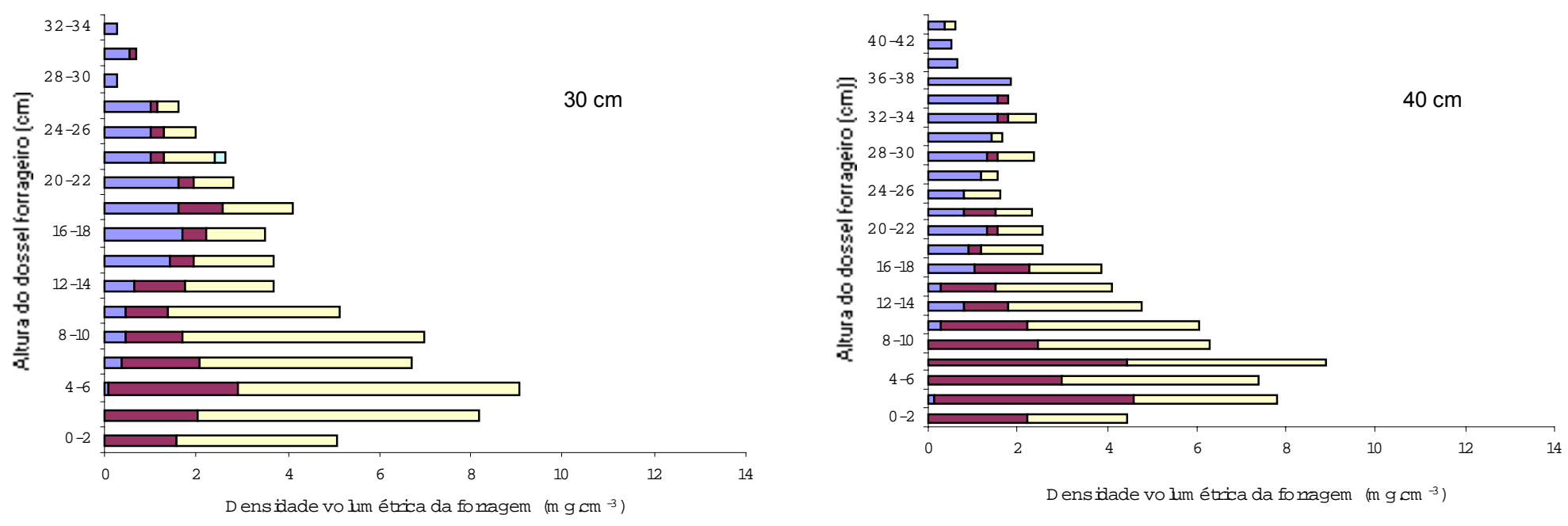

$\square^{F \circ}$ ha $\square^{\text {Haste }} \square^{\mathrm{M} \text { aterialM }}$ orto $\square^{\text {hivasoras }}$

$\square^{\text {Fo ha }} \mathbf{Q}^{\text {Haste }} \mathbf{Q}^{\mathrm{M} \text { aterialM }}$ orto $\mathbf{Q}^{\text {Invasoras }}$

Figura 15 - Estrutura do dossel forrageiro de Brachiaria brizantha cv Marandu mantida em quatro alturas de pasto sob lotação contínua (10, 20, 30 e $40 \mathrm{~cm})$ durante o mês de maio de 2002. 

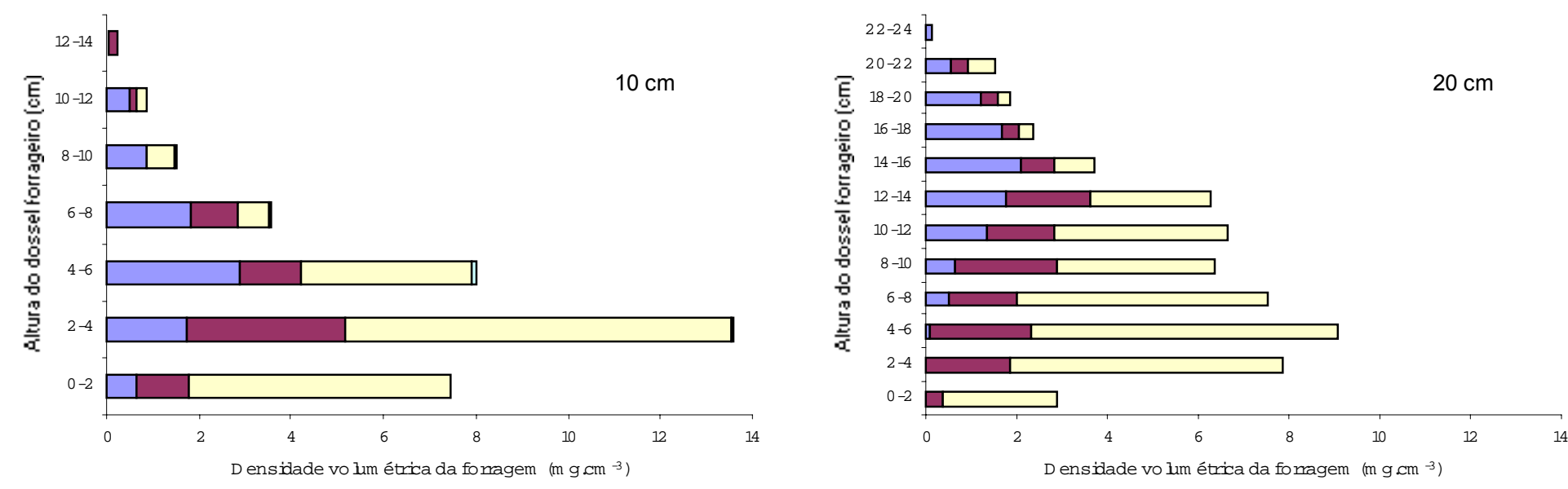

$\square^{\mathrm{F} \circ \text { ha }} \mathbf{\square}^{\text {Haste }} \square^{\mathrm{M} \text { aterialM }}$ orto $\square^{\text {Invasoras }}$

$\mathbf{Q}^{\mathrm{F} \circ \text { hha }} \mathbf{\square}^{\text {Haste }} \mathbf{\square}^{\mathrm{M} \text { aterialM } \circ \text { rto }} \mathbf{\square}^{\text {hivasoras }}$
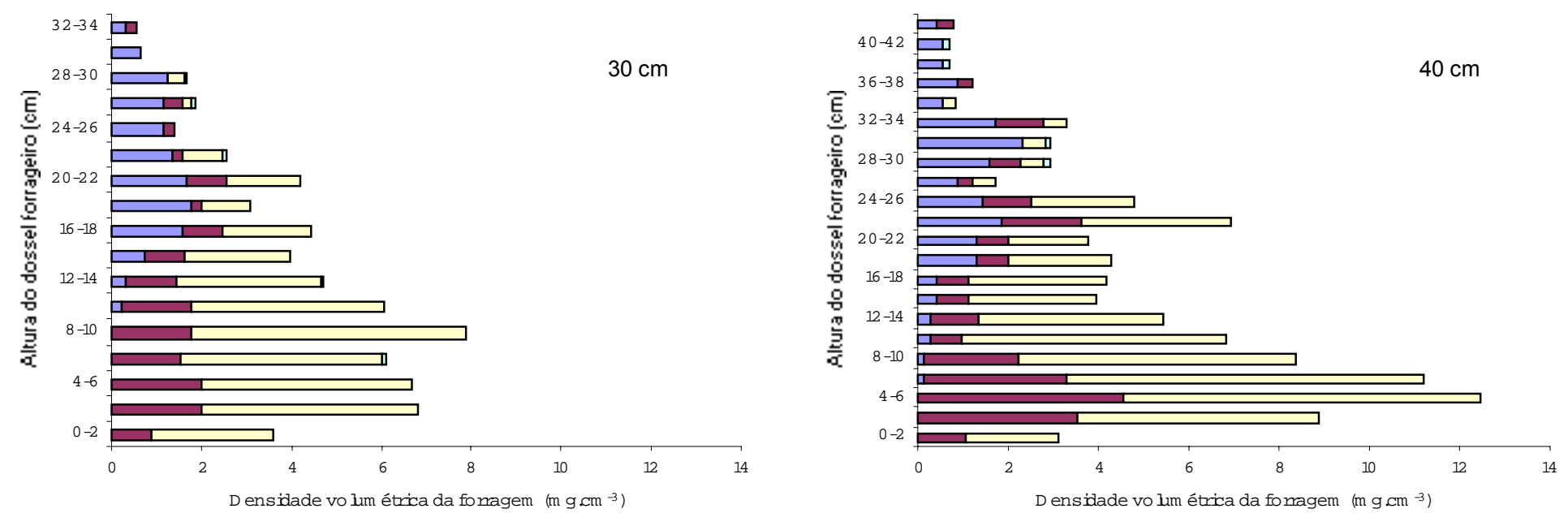

$\square^{F \circ}$ ha $\square^{\text {Haste }} \square^{\mathrm{M} \text { aterialM }}$ orto $\square^{\text {hivasoras }}$

$\square^{F \circ \text { ha }} \square^{\text {Haste }} \square^{M}$ aterialM orto $\square$ hvasoras

Figura 16 - Estrutura do dossel forrageiro de Brachiaria brizantha cv Marandu mantida em quatro alturas de pasto sob lotação contínua (10, 20, 30 e $40 \mathrm{~cm}$ ) durante o mês de julho de 2002. 

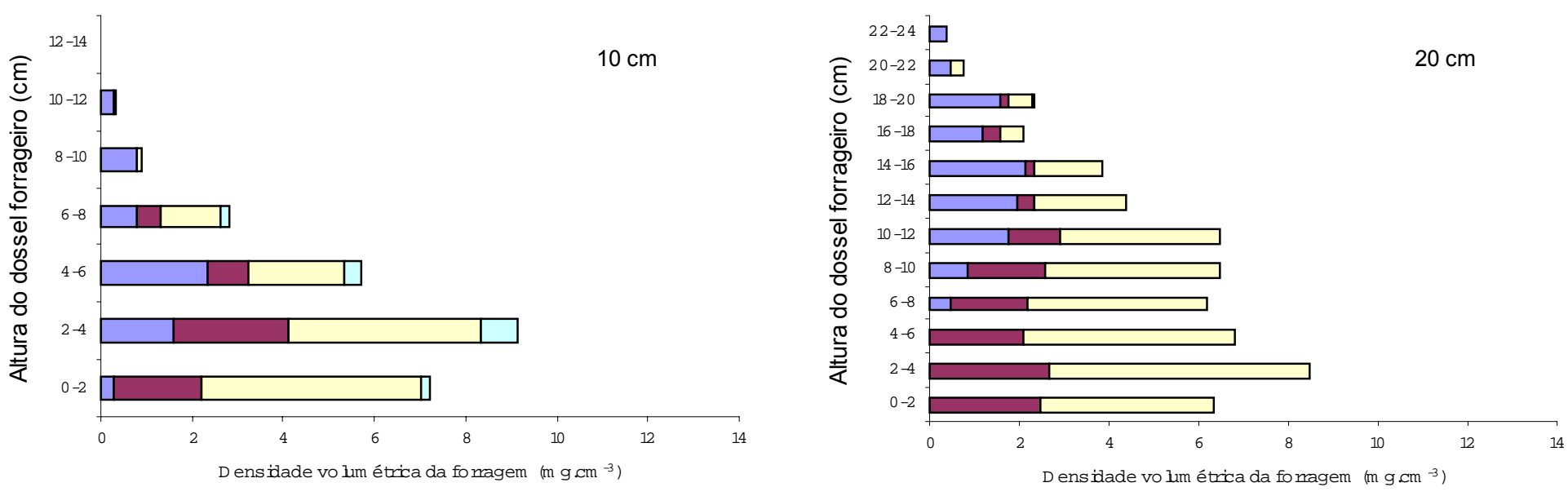

$\square^{\text {Folha }} \square^{\text {Haste }} \square^{\text {M aterialM orto }} \square^{\text {hvasoras }}$

$\square^{\mathrm{F} O \text { Tha }} \mathbf{\square}^{\text {Haste }} \mathbf{\square}^{\mathrm{M}}$ aterialM orto $\mathbf{\square}^{\text {Invasoras }}$
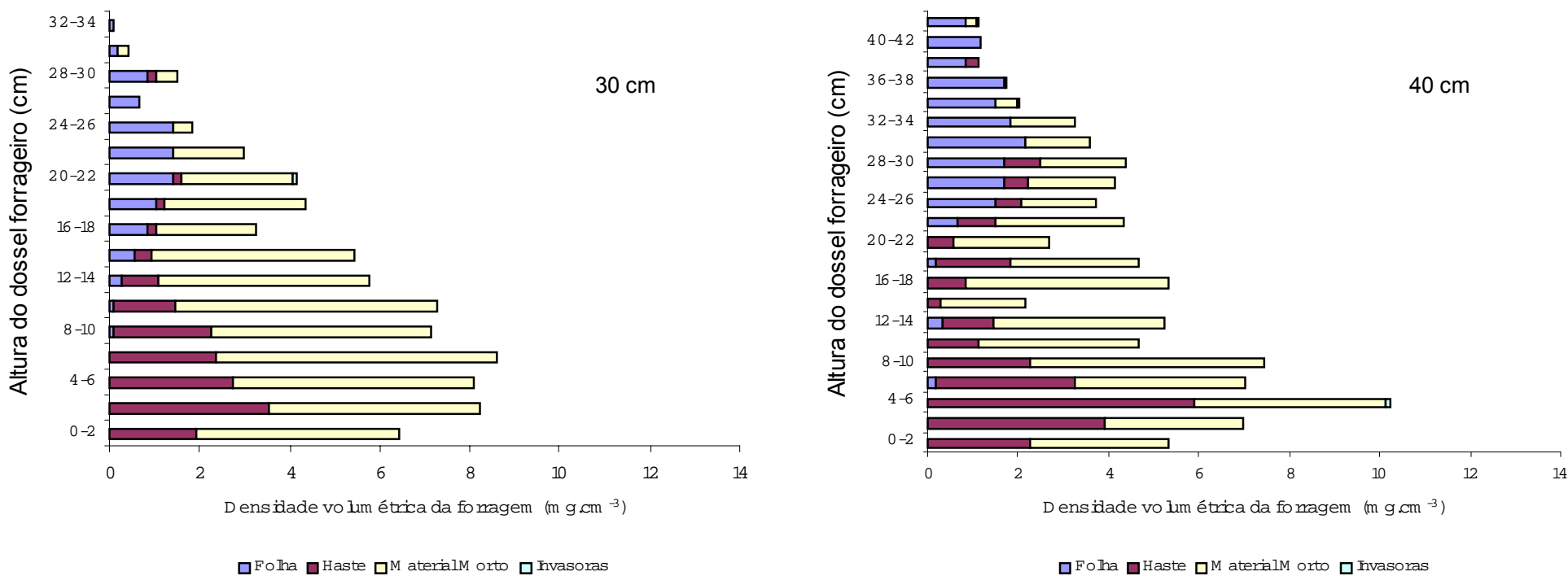

Figura 17 - Estrutura do dossel forrageiro de Brachiaria brizantha cv Marandu mantida em quatro alturas de pasto sob lotação contínua (10, 20, 30 e $40 \mathrm{~cm}$ ) durante o mês de agosto de 2002. 

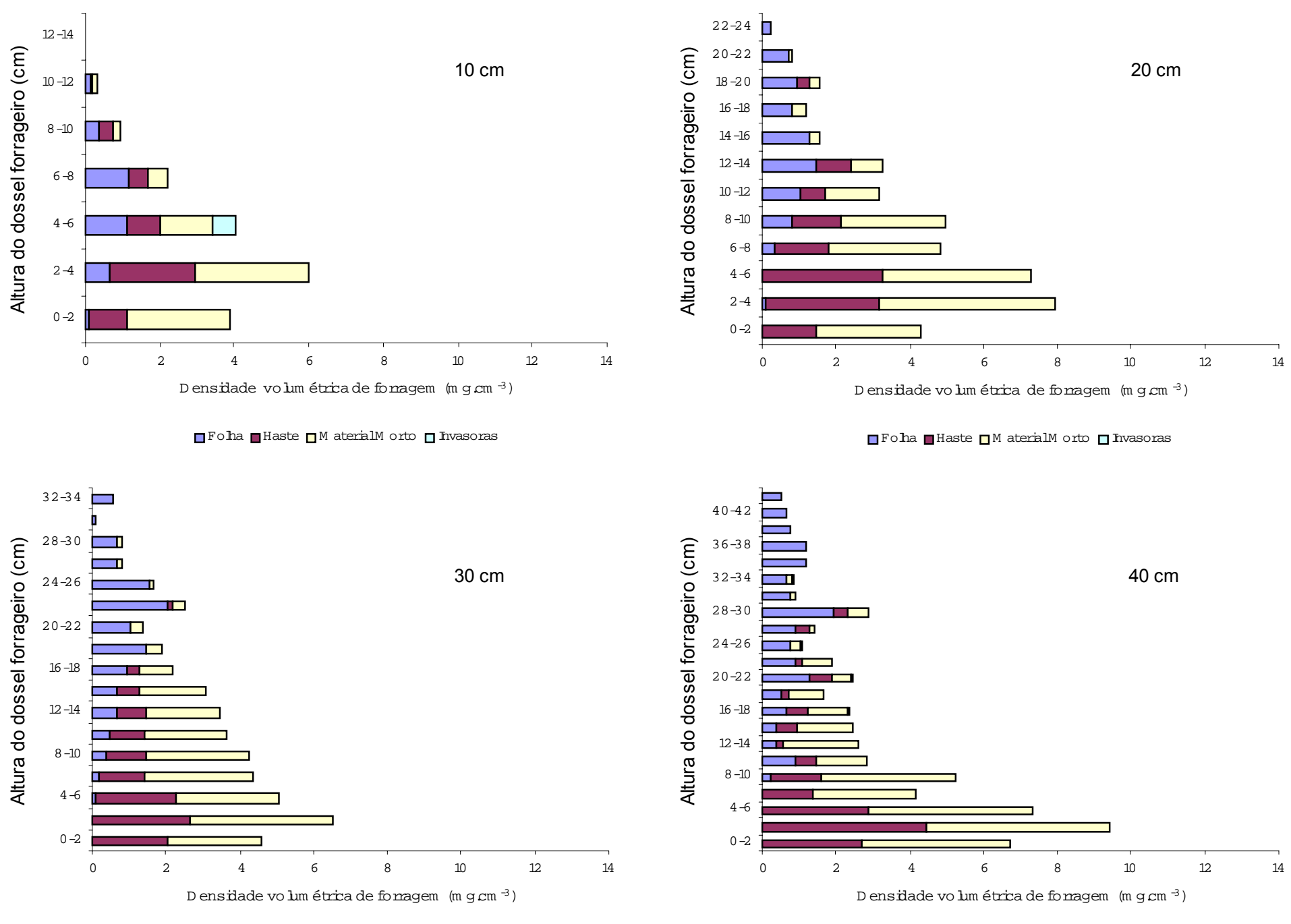

$\mathbf{Q}^{\mathrm{F} \circ \text { hha }} \mathbf{Q}^{\text {Haste }} \mathbf{Q}^{\mathrm{M} \text { aterialM }}$ orto $\square^{\text {hivasoras }}$

$\square^{\mathrm{F} \circ \text { ha }} \mathbf{Q}^{\text {Haste }} \square^{\mathrm{M} \text { aterialM }}$ orto $\square^{\text {Invasoras }}$

Figura 18 - Estrutura do dossel forrageiro de Brachiaria brizantha cv Marandu mantida em quatro alturas de pasto sob lotação contínua (10, 20, 30 e $40 \mathrm{~cm}$ ) durante o mês de dezembro de 2002. 
massa correspondente às folhas verdes no terço superior do dossel forrageiro, situação que foi sendo gradativamente revertida com o final do inverno.

Os valores médios relativos à composição botânica e morfológica da forragem no dossel forrageiro encontram-se sumarizados na Tabela 3.

Tabela 3. Densidade volumétrica (DV) em $\mathrm{mg} \cdot \mathrm{cm}^{-3}$ e estrato potencialmente pastejável (EPP) da forragem, para as alturas de dossel forrageiro avaliadas.

\begin{tabular}{ccccccccc}
\hline & \multicolumn{7}{c}{ Altura do dossel forrageiro (cm) } \\
Meses & DV & EPP* & DV & EPP* & DV & EPP* & DV & EPP* \\
\hline Janeiro & 4,18 & 2,09 & 4,37 & 2,18 & 3,89 & 1,95 & 3,84 & 1,92 \\
Fevereiro & 5,79 & 2,90 & 4,45 & 2,22 & 4,45 & 2,21 & 3,53 & 1,77 \\
Maio & 4,62 & 2,31 & 4,49 & 2,24 & 4,43 & 2,21 & 3,85 & 1,92 \\
Julho & 7,05 & 3,52 & 5,63 & 2,81 & 4,41 & 2,20 & 4,98 & 2,49 \\
Agosto & 5,23 & 2,62 & 5,46 & 2,73 & 5,08 & 2,54 & 4,66 & 2,33 \\
Dezembro & 3,49 & 1,74 & 4,11 & 2,06 & 3,17 & 1,58 & 3,03 & 1,51 \\
Média & 5,06 & 2,53 & 4,75 & 2,38 & 4,24 & 2,12 & 3,98 & 1,99 \\
\hline
\end{tabular}

EPP $^{\star}$ - estrato $50 \%$ superior do dossel forrageiro

Nota-se, de modo geral, que a densidade volumétrica média diminuiu com o aumento da altura do dossel forrageiro e que, menores valores de densidade volumétrica foram obtidos nos meses em que as lâminas foliares tiveram a maior contribuição na composição morfológica, como pode ser observado nos meses de janeiro, fevereiro e dezembro. No estrato potencialmente pastejável ( $50 \%$ superior da altura do dossel) os valores de densidade volumétrica da forragem em janeiro foram cerca de $80 \%$ superiores aos valores de dezembro de 2002, fato este que pode influenciar a ingestão de forragem de animais em pastejo quando ofertados pastos naquelas condições 
por reduzir a profundidade de bocados e, consequentemente, o tamanho de bocados. Indica, também, que pastos mantidos numa mesma condição de equilíbrio (altura de dossel forrageiro), podem dependendo da época do ano, propiciar diferentes valores de consumo de forragem.

\subsection{Comportamento ingestivo}

\subsubsection{Tamanho de bocado (TB)}

Os dados referentes ao tamanho de bocado estimado através da utilização de animais portadores de cânulas esofagianas são apresentados na Tabela 4 e Figuras 19 e 20. Houve efeito de altura do dossel forrageiro ( $P<$ $0,0001)$, não tendo sido verificado efeito de mês do ano $(P=0,2264)$ e da interação altura do dossel:mês do ano $(P=0,8311)$. Os valores médios de TB nos meses avaliados variaram entre $0,5(10 \mathrm{~cm}$, agosto e fevereiro) e $1,7 \mathrm{~g}$ MS.bocado ${ }^{-1}$ (40 cm, agosto). Não houve diferença para os valores de TB entre esses meses.

Tabela 4. Tamanho de bocado (g MS.bocado ${ }^{-1}$ ) de animais portadores de cânulas esofagianas mantidos em pastos de capim-Marandu submetidos a quatro alturas de dossel forrageiro, em agosto de 2002 e fevereiro de 2003.

\begin{tabular}{ccccccc}
\hline \multirow{2}{*}{ Mês } & \multicolumn{6}{c}{ Altura $(\mathrm{cm})$} \\
& 10 & 20 & 30 & 40 & Média & \multirow{2}{*}{ EPM $^{*}$} \\
\hline Agosto & 0,5 & 0,8 & 1,3 & 1,7 & 1,1 & 0,06 \\
Fevereiro & 0,5 & 0,8 & 1,2 & 1,4 & 0,9 & 0,08 \\
& & & & & & \\
Média & $0,5^{\mathrm{a}}$ & $0,8^{\mathrm{b}}$ & $1,2^{\mathrm{c}}$ & $1,5^{\mathrm{d}}$ & & \\
EPM $^{*}$ & 0,11 & 0,10 & 0,10 & 0,10 & & \\
\hline
\end{tabular}

$\mathrm{EPM}^{*}$ - Erro padrão da média Médias na linha seguidas de mesmas letras minúsculas não diferem entre si $(P>0,10)$ 


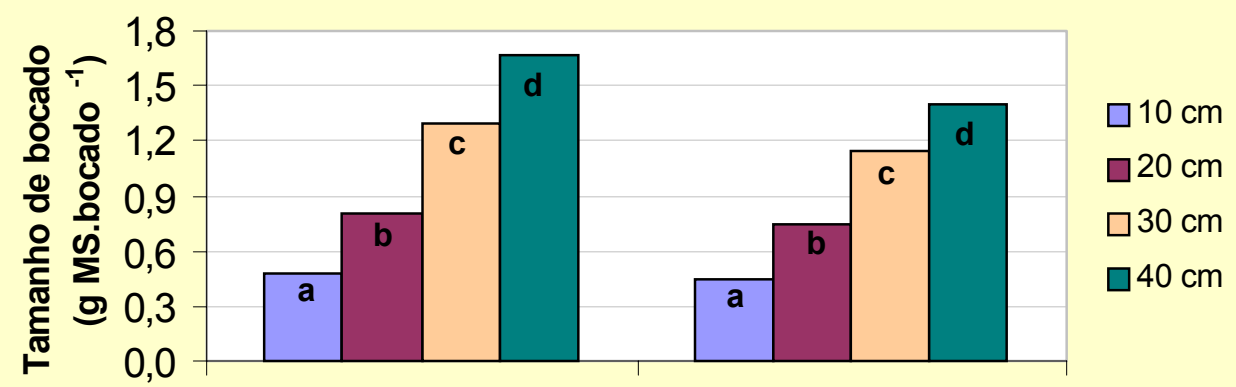

Agosto

Fevereiro

\section{Mês de avaliação}

Figura 19 - Tamanho de bocado (g MS.bocado ${ }^{-1}$ ) de animais mantidos em pastos de capim-Marandu submetidos a quatro alturas de dossel forrageiro, em agosto de 2002 e fevereiro de 2003.

O tamanho de bocado respondeu de forma crescente ao aumento em altura do dossel forrageiro, com os valores estimados para o tratamento de $40 \mathrm{~cm}$ sendo três vezes maior que o correspondente ao tratamento de $10 \mathrm{~cm}$. Tal padrão de resposta foi verificado também por Brâncio et al. (2000) com animais portadores de cânulas esofagianas que, trabalhando com os cultivares Tanzânia, Mombaça e Massai do gênero Panicum maximum Jacq., em regime de lotação intermitente, obtiveram valores variando de 0,2 a $1,0 \mathrm{~g}$ de $M_{S}$.bocado ${ }^{-1}$. Tais resultados são concordantes com a afirmativa de Hodgson (1985 b) que define o tamanho do bocado como sendo a variável mais influenciada pela altura do dossel forrageiro. Essa relação ocorre independentemente do método de pastejo empregado e em espécies morfologicamente contrastantes como o azevém perene (Lolium perenne L.) e o trevo branco (Trifolium repens L.) (Wade, 1991; Edwards et al., 1995).

A consistente relação observada entre as características inerentes à estrutura do dossel forrageiro e o padrão de resposta obtido para o tamanho de bocado parece ilustrar com bastante fidelidade o cenário descrito por Laca et al. (1992). De acordo com esses autores, quanto menor a altura das plantas, mais 
densa é a forragem (Tabela 3) e menos efetiva é a capacidade dos animais em ampliar a quantidade de forragem trazida até a boca (Tabela 4). Segundo Burlison et al. (1991) a altura da planta está relacionada diretamente com o aumento do tamanho de bocado, tendo um comportamento linear com o aumento da altura da planta, razão pela qual, a profundidade do bocado guarda uma relação positiva com a altura do dossel forrageiro e negativa em relação à densidade volumétrica da forragem (Gordon \& Lascano, 1993) (Tabela 3).

\subsubsection{Taxa de bocados}

Os resultados referentes a taxa de bocados são mostrados na Tabela 5 e Figura 20. Houve influência de altura do dossel forrageiro ( $P<$ $0,0001)$, mês do ano $(P<0,0001)$ e da interação altura do dossel:mês do ano ( $P<0,0001)$. A amplitude dos valores médios durante o período experimental foi de 16,5 (40 cm, fevereiro) a 55,2 bocados.minuto ${ }^{-1}(10 \mathrm{~cm}$, maio). Animais mantidos nos pastos de $10 \mathrm{~cm}$ (51,3 bocados.minuto $\left.{ }^{-1}\right)$ apresentaram a maior taxa de bocados durante o experimento enquanto os animais mantidos em pastos de $40 \mathrm{~cm}$ apresentaram a Taxa mais reduzida (17,7 bocados.minutos $\left.{ }^{-1}\right)$ (Figura 21). Ao mesmo tempo em que se reduziu a altura do estrato potencialmente pastejável com o decréscimo da altura do dossel forrageiro, reduziu-se a massa de forragem e a quantidade apreendida a cada bocado. Nessa situação, com o intuito de tentar manter a ingestão de forragem, os animais aumentaram, além da taxa de bocados, o tempo de pastejo (Item 4.3.3). Os valores observados confirmam a afirmativa de que dificilmente animais em pastejo conseguem realizar mais de 4000 bocados por hora (Stobbs, 1973a).

Os valores observados apresentam uma amplitude semelhante àquela reportada por Brâncio et al. (2000) que, em observações ao longo do período de ocupação dos piquetes, obtiveram taxas variando de 27,3 a 47,1 bocados.minuto ${ }^{-1}$ nos diferentes tratamentos e épocas do ano avaliados. 
Tabela 5. Taxa de bocados (bocados.minuto ${ }^{-1}$ ) de animais mantidos em pastos de capim-Marandu submetidos a quatro alturas de dossel forrageiro.

\begin{tabular}{|c|c|c|c|c|c|c|}
\hline \multirow{2}{*}{ Mês } & \multicolumn{4}{|c|}{ Altura $(\mathrm{cm})$} & \multirow[t]{2}{*}{ Média } & \multirow[t]{2}{*}{$\mathrm{EPM}^{*}$} \\
\hline & 10 & 20 & 30 & 40 & & \\
\hline Janeiro & 40,1 & 30,1 & 23,4 & 17,4 & $27,7^{\mathrm{E}}$ & 0,69 \\
\hline Fevereiro & 39,8 & 28,0 & 23,2 & 16,5 & $26,8^{\mathrm{F}}$ & 0,69 \\
\hline Maio & 55,2 & 30,3 & 23,9 & 17,0 & $31,6^{\mathrm{B}}$ & 0,69 \\
\hline Julho & 41,1 & 28,2 & 24,5 & 19,0 & $28,1^{\mathrm{D}}$ & 0,69 \\
\hline Agosto & 48,1 & 33,1 & 24,1 & 17,0 & $30,6^{C}$ & 0,69 \\
\hline Dezembro & 53,4 & 32,5 & 23,9 & 18,1 & $32,0^{A}$ & 0,69 \\
\hline Média & $46,3^{a}$ & $30,3^{b}$ & $23,8^{\mathrm{C}}$ & $17,5^{\mathrm{d}}$ & & \\
\hline EPM & 0,56 & 0,56 & 0,56 & 0,56 & & \\
\hline
\end{tabular}

EPM $^{*}$ - Erro padrão da média

Médias na linha seguidas de mesmas letras minúsculas não diferem entre si $(P>0,10)$

Médias na coluna seguidas de mesmas letras maiúsculas não diferem entre si $(P>0,10)$

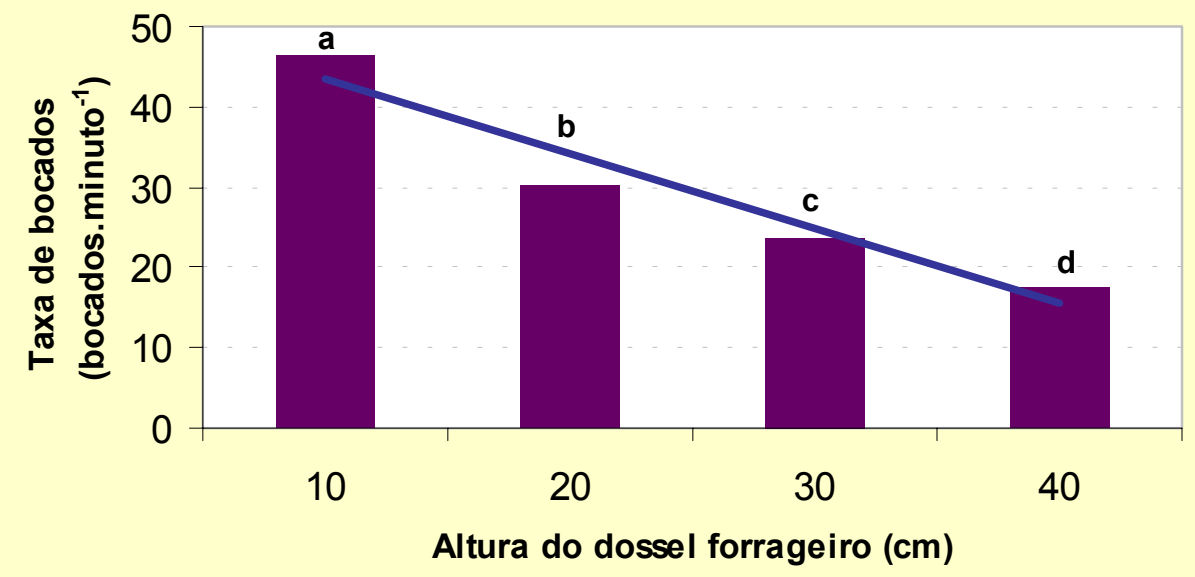

Figura 20 - Taxa de bocados (bocados.minuto ${ }^{-1}$ ) de animais mantidos em pastos de capim-Marandu submetidos a quatro alturas de dossel forrageiro. 


\subsubsection{Tempo de pastejo (TP), ruminação (TR) e ócio (TO)}

Os resultados referentes ao tempo de pastejo são mostrados na Tabela 6 e Figura 21. O tempo de pastejo foi influenciado pela altura do dossel forrageiro $(P<0,0001)$ e pelo mês do ano $(P=0,0019)$. Não houve efeito da interação altura do dossel:mês do ano $(P=0,4848)$. A amplitude dos valores durante o período experimental foi de $9,4\left(30 \mathrm{~cm}\right.$, fevereiro) a 12,5 horas.dia $^{-1}$ (30 cm, julho) (Tabela 6). Animais mantidos nos pastos de $10 \mathrm{~cm}(11,37$ horas. $\mathrm{dia}^{-1}$ ) apresentaram o maior TP durante o experimento, o qual diferiu dos valores relativos às demais alturas de dossel forrageiro estudadas (Figura 21).

Tabela 6. Tempo de pastejo (horas.dia ${ }^{-1}$ ) de animais mantidos em pastos de capim-Marandu submetidos a quatro alturas de dossel forrageiro, nos meses de janeiro, fevereiro, maio, julho, agosto e dezembro de 2002.

\begin{tabular}{|c|c|c|c|c|c|c|}
\hline \multirow{2}{*}{ Mês } & \multicolumn{4}{|c|}{ Altura $(\mathrm{cm})$} & \multirow{2}{*}{ Média } & \multirow{2}{*}{ EPM $^{*}$} \\
\hline & 10 & 20 & 30 & 40 & & \\
\hline Janeiro & 10,9 & 10,4 & 10,0 & 11,0 & $10,6^{C}$ & 0,23 \\
\hline Fevereiro & 10,6 & 10,0 & 9,4 & 10,2 & $10,1^{\mathrm{C}}$ & 0,28 \\
\hline Maio & 11,4 & 9,9 & 10,6 & 10,1 & $10,5^{\mathrm{BC}}$ & 0,32 \\
\hline Julho & 12,1 & 12,3 & 12,5 & 11,5 & $12,1^{\mathrm{A}}$ & 0,36 \\
\hline Agosto & 10,7 & 10,1 & 10,5 & 9,9 & $10,3^{C}$ & 0,32 \\
\hline Dezembro & 12,5 & 11,3 & 10,7 & 10,2 & $11,2^{\mathrm{B}}$ & 0,24 \\
\hline Média & $11,4^{a}$ & $10,7^{b}$ & $10,6^{b}$ & $10,5^{b}$ & & \\
\hline EPM & 0,21 & 0,22 & 0,22 & 0,28 & & \\
\hline
\end{tabular}

EPM $^{*}$ - Erro padrão da média

Médias na linha seguidas de mesmas letras minúsculas não diferem entre si $(P>0,10)$

Médias na coluna seguidas de mesmas letras maiúsculas não diferem entre si $(P>0,10)$ 


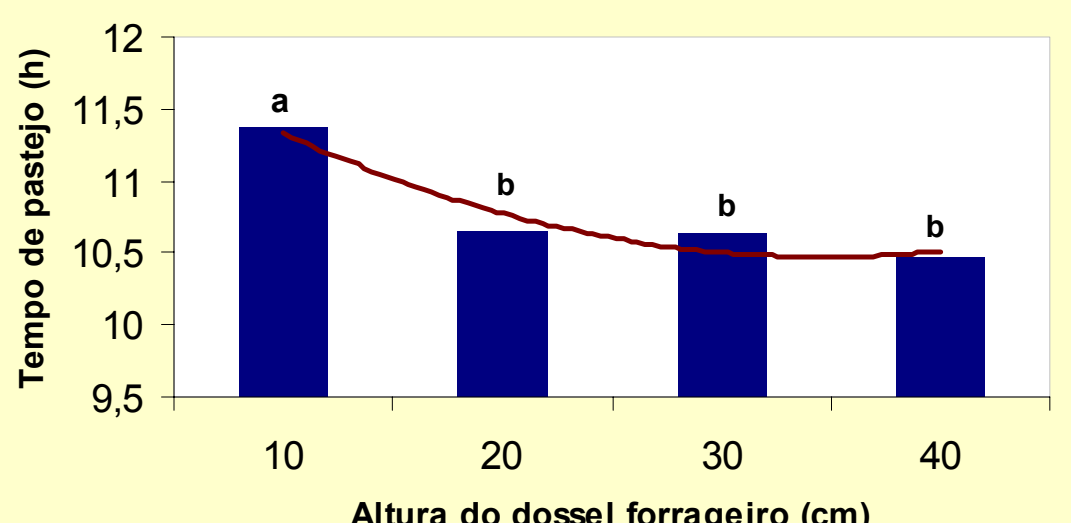

Altura do dossel forrageiro $(\mathrm{cm})$

LLinha de tendêncí

Figura 21 - Tempo de pastejo (horas.dia ${ }^{-1}$ ) de bovinos de corte em pastos de capim-Marandu mantidos em quatro alturas de dossel forrageiro.

Os valores observados para tempo de pastejo apresentaram uma tendência de aumento à medida que se reduziu a altura do dossel forrageiro. Em pastos mantidos a $10 \mathrm{~cm}$ os animais gastaram cerca de uma hora a mais em atividade de pastejo se comparados a animais mantidos em pastos de 40 $\mathrm{cm}$. Os tempos de pastejo verificados encontram-se dentro da amplitude descrita como aceitável por Hodgson et al. (1994). Esses autores afirmaram que o tempo de pastejo é normalmente de 8 horas, podendo atingir até 16 horas em casos extremos, padrão de atividade que corrobora com a afirmativa de Cosgrove (1997) de que a diminuição da massa de forragem provoca aumento no tempo de pastejo.

Nos meses de maio, julho e agosto houve um aumento no acúmulo de material morto na base do dossel, provavelmente tendo sido esta a causa para o aumento no tempo de pastejo dos animais naquela época do ano, uma vez que maior esforço pode ter sido despendido em atividades de procura e seleção de bocados potenciais. Tal proposição é condizente com a afirmativa de L 'Huillier et al. (1986), que menciona uma dependência existente entre a desfolhação realizada pelo animal e os elementos inerentes à estrutura do 
dossel forrageiro, segundo a qual determinados componentes da planta são preferidos em relação a outros.

Vale ressaltar que os valores obtidos não são relativos à atividade de pastejo efetivo (tempo gasto pelos animais na apreensão da forragem), mas compreendem, também, os processos de seleção e procura. Dessa forma, existe a necessidade de se determinar o tempo gasto na apreensão da forragem, principalmente quando se tem a intenção de se comparar alternativas para se estimar o tamanho de bocado (g MS.bocado ${ }^{-1}$ ). Nesses casos, o valor estimado por meio da divisão do consumo diário pelo número de bocados realizados no dia será, na maioria das vezes, subestimado, se comparado a valores de tamanho de bocado obtidos através da utilização de animais portadores de cânulas esofagianas, por exemplo. Nesse caso o tempo de pastejo seria considerado como tempo gasto somente em ingestão de forragem, superestimando o número total de bocados realizados no dia. Isso provavelmente ocorreu no trabalho realizado por Brâncio et al. (2000), que estimaram o tamanho de bocado utilizando o consumo diário de forragem dividido pelo número total de bocados realizados no dia, procedimento que resultou em valores de estimativas cerca de 2,2 vezes inferiores àquelas geradas com o uso de animais portadores de cânulas esofagianas.

Com relação ao tempo de ruminação (TR), houve efeito de altura do dossel forrageiro $(P=0,0106)$ e de mês do ano $(P<0,001)$. Não houve efeito de interação altura do dossel:mês do ano $(P=0,6960)$, como pode ser observado na Tabela 7 e Figura 22. A amplitude dos valores de TR durante o período experimental foi de 2,5 (40 cm, julho) a 8,8 horas.dia-1 ${ }^{-1}(30 \mathrm{~cm}$, janeiro). Animais mantidos nos pastos de $30 \mathrm{~cm}$ apresentaram o maior valor médio de TR durante o experimento $\left(6,6\right.$ horas. dia $\left.^{-1}\right)$, o qual diferiu dos valores relativos aos observados para animais mantidos nos pastos de 20 e $40 \mathrm{~cm}$. O menor TR para animais mantidos nos pastos de $10 \mathrm{~cm}\left(5,1\right.$ horas. dia $\left.^{-1}\right)$ provavelmente ocorreu pela restrição quantitativa a que foram submetidos (menor massa de forragem), situação contrastante àquela observada em animais mantidos nos 
pastos de $40 \mathrm{~cm}$ (5,6 horas. dia $\left.{ }^{-1}\right)$ onde, devido ao maior consumo de matéria seca (Item 4.4), provavelmente o tempo de retenção da forragem ingerida no rúmen foi inferior em função do estimulo à ingestão (Forbes, 1993).

Tabela 7. Tempo de ruminação (horas dia $^{-1}$ ) de animais mantidos em pastos de capim-Marandu submetidos a quatro alturas de dossel forrageiro, nos meses de janeiro, fevereiro, maio, julho, agosto e dezembro de 2002.

\begin{tabular}{|c|c|c|c|c|c|c|}
\hline \multirow{2}{*}{ Mês } & \multicolumn{4}{|c|}{ Altura (cm) } & \multirow{2}{*}{ Média } & \multirow{2}{*}{$\mathrm{EPM}^{*}$} \\
\hline & 10 & 20 & 30 & 40 & & \\
\hline Janeiro & 6,8 & 7,5 & 8,8 & 8,3 & $7,8^{A}$ & 0,40 \\
\hline Fevereiro & 4,8 & 6,3 & 6,3 & 4,5 & $5,5^{\mathrm{B}}$ & 0,44 \\
\hline Maio & 4,6 & 5,6 & 5,9 & 5,7 & $5,5^{\mathrm{B}}$ & 0,54 \\
\hline Julho & 3,3 & 4,2 & 6,0 & 2,5 & $5,0^{\mathrm{C}}$ & 0,58 \\
\hline Agosto & 5,9 & 4,6 & 5,4 & 5,4 & $5,3^{B C}$ & 0,53 \\
\hline Dezembro & 5,3 & 7,7 & 7,3 & 7,2 & $6,9^{A}$ & 0,40 \\
\hline Média & $5,1^{\mathrm{c}}$ & $6,0^{\mathrm{b}}$ & $6,6^{a}$ & $5,6^{\mathrm{bc}}$ & & \\
\hline EPM & 0,23 & 0,25 & 0,26 & 0,42 & & \\
\hline
\end{tabular}

EPM $^{*}$ - Erro padrão da média

Médias na linha seguidas de mesmas letras minúsculas não diferem entre si $(P>0,10)$

Médias na coluna seguidas de mesmas letras maiúsculas não diferem entre si $(P>0,10)$

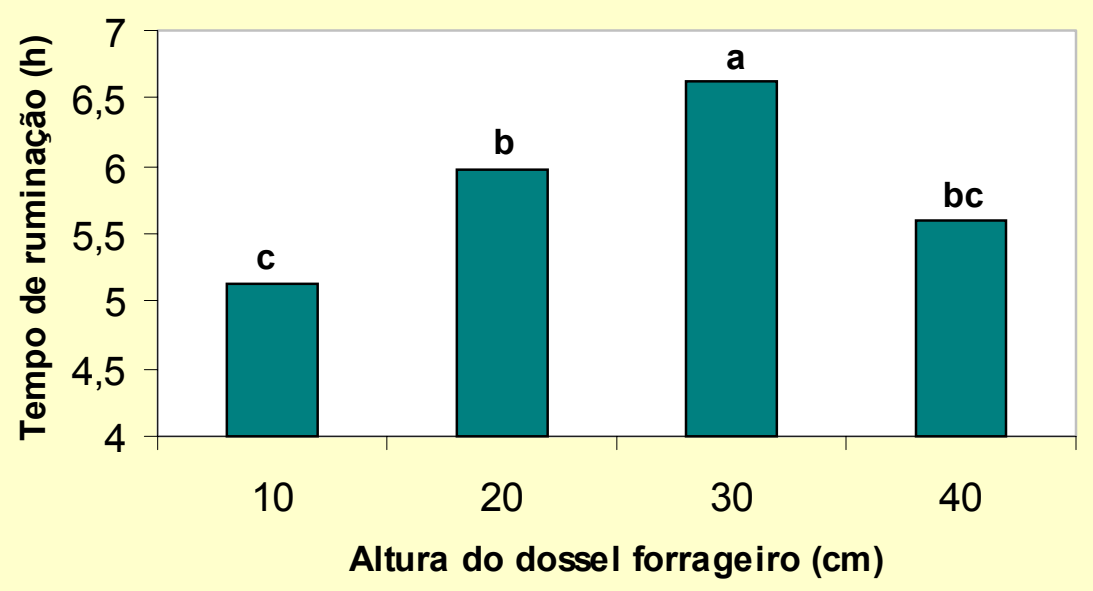

Figura 22 - Tempo de ruminação (horas.dia ${ }^{-1}$ ) de bovinos de corte em pastos de capim-Marandu mantidos em quatro alturas de dossel forrageiro. 
Com relação ao tempo de ócio, houve efeito de mês $(P<0,001)$. Não houve efeito de altura do dossel forrageiro $(P=0,4421)$ e da interação altura do dossel:mês $(P=0,9114)$. Os valores relativos ao tempo gasto pelos animais em ócio são apresentados na Tabela 8.

Tabela 8. Tempo de ócio (horas.dia ${ }^{-1}$ ) de animais mantidos em pastos de capim-Marandu submetidos a quatro alturas de dossel forrageiro nos meses de janeiro, fevereiro, maio, julho, agosto e dezembro de 2002.

\begin{tabular}{ccccccc}
\hline \multirow{2}{*}{ Mês } & \multicolumn{5}{c}{ Altura $(\mathrm{cm})$} & \multicolumn{3}{c}{ Média } & EPM $^{*}$ \\
& 10 & 20 & 30 & 40 & & \\
\hline Janeiro & 6,5 & 6,2 & 5,3 & 5,5 & $5,9^{\mathrm{B}}$ & 0,25 \\
Fevereiro & 8,8 & 8,2 & 8,0 & 9,0 & $8,5^{\mathrm{A}}$ & 0,33 \\
Maio & 7,7 & 8,4 & 7,6 & 7,9 & $7,9^{\mathrm{A}}$ & 0,86 \\
Julho & 8,1 & 7,8 & 6,3 & 8,3 & $7,6^{\mathrm{A}}$ & 0,34 \\
Agosto & 7,7 & 9,6 & 8,1 & 9,3 & $8,7^{\mathrm{A}}$ & 0,76 \\
Dezembro & 6,3 & 5,6 & 6,2 & 6,7 & $6,2^{\mathrm{B}}$ & 0,34 \\
& & & & & & \\
Média & 7,5 & 7,7 & 6,9 & 7,8 & & \\
EPM & 0,33 & 0,37 & 0,35 & 0,52 & &
\end{tabular}

EPM $^{*}$ - Erro padrão da média

Médias na coluna seguidas de mesmas letras maiúsculas não diferem entre si $(P>0,10)$

O tempo gasto pelos animais em atividades de pastejo, ruminação e ócio foi, independente do tratamento, distribuído de forma muito consistente ao longo das 24 horas do dia (Figura 23 e 24). Foram observados dois períodos bem definidos de pastejo durante o dia e um pastejo noturno, confirmando o exposto por Cosgrove (1997), que afirmou que animais em pastejo apresentam três a cinco picos de pastejo no decorrer do dia, sendo que os mais intensos ocorrem no início da manhã e no final da tarde. Segundo Krysl \& HESS (1993), os animais realizam 65 a $100 \%$ de sua atividade de pastejo entre as 6 horas da manhã e às 7 horas da noite. 

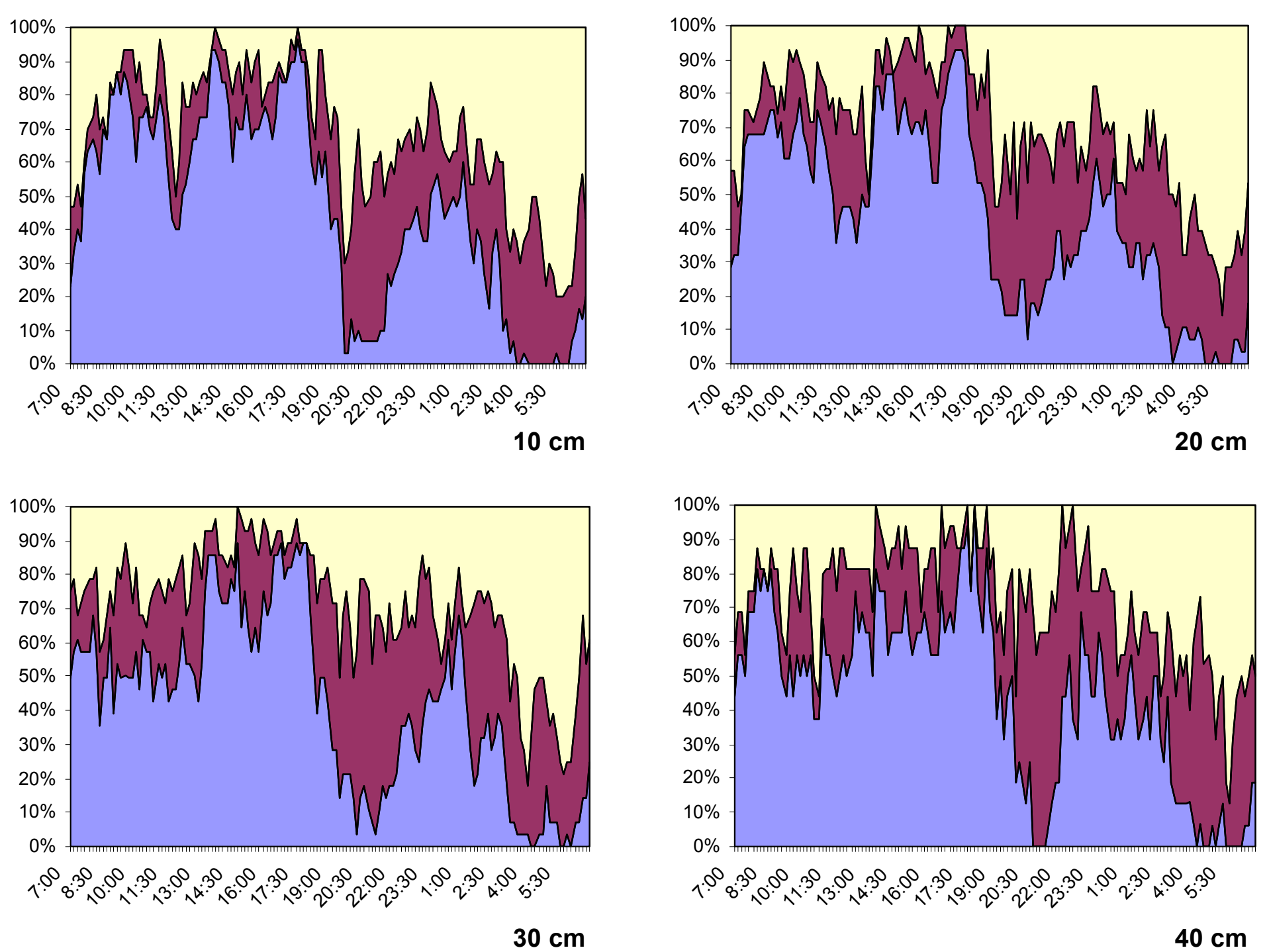

Figura - 23 Tempo de pastejo ( $\Delta$ ), ruminação $(\Delta)$ e ócio $(\Delta)$, expressos em \% dos animais observados, em pastos de capim-Marandu mantidos em quatro alturas de dossel forrageiro. 


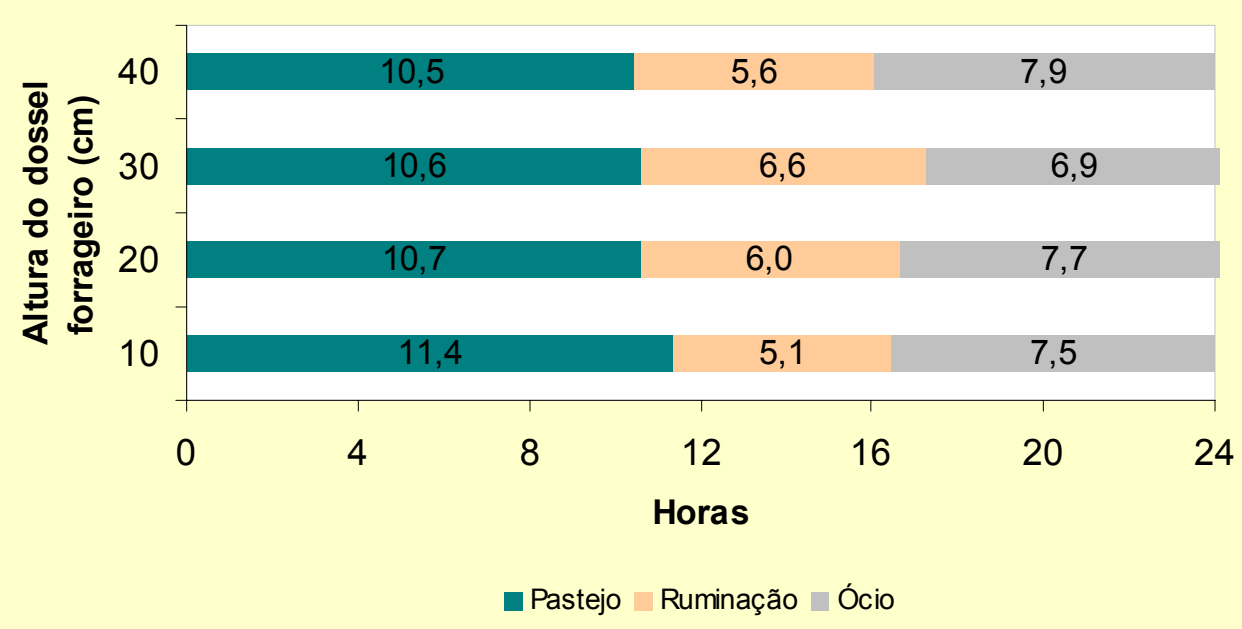

Figura 24 - Tempo de pastejo, ruminação e ócio (horas.dia-1 ${ }^{-1}$ de bovinos de corte em pastos de capim-Marandu mantidos em quatro alturas de dossel forrageiro.

\subsection{Consumo de forragem (CF)}

Os valores referentes ao consumo diário de forragem estimado pelo método de n-alcanos nos meses de janeiro e dezembro são apresentados na Tabela 9 e Figura 25. O consumo diário de forragem foi influenciado pela altura do dossel forrageiro $(P=0,0001)$ e pelo mês do ano $(P=0,0001)$. Não houve efeito da interação altura do dossel:mês do ano $(P=0,2301)$. A amplitude dos valores médios de CF nos meses avaliados foi de 1,3 (10 cm, janeiro) e 2,2 kg MS. $100 \mathrm{kgPV}^{-1}$ (40 cm, agosto). Animais mantidos nos pastos de $10 \mathrm{~cm}$ apresentaram um consumo quase $60 \%$ inferior quando comparados àqueles mantidos nos pastos de $40 \mathrm{~cm}$. Tais resultados são concordantes com a afirmativa de Nussio et al. (1998), que define o consumo diário mínimo de pasto em torno de $2 \%$ do peso vivo devido à seleção, podendo ser ainda mais reduzido se houver restrição física (dificuldade de apreensão) e/ou o valor nutritivo da forragem for baixo. 
Tabela 9. Consumo de forragem em $\mathrm{kg} \mathrm{MS.100kgPV}^{-}$de animais mantidos em pastos de capim-Marandu submetidos a quatro alturas de dossel forrageiro nos meses de janeiro e dezembro de 2002.

\begin{tabular}{|c|c|c|c|c|c|c|}
\hline \multirow{2}{*}{ Mês } & \multicolumn{4}{|c|}{ Altura $(\mathrm{cm})$} & \multirow[t]{2}{*}{ Média } & \multirow[t]{2}{*}{$\mathrm{EPM}^{\prime}$} \\
\hline & 10 & 20 & 30 & 40 & & \\
\hline Janeiro & 1,3 & 1,6 & 1,6 & 1,8 & $1,6^{\mathrm{A}}$ & 0,06 \\
\hline Dezembro & 1,4 & 2,0 & 2,1 & 2,2 & $1,9^{B}$ & 0,04 \\
\hline Média & $1,3^{\mathrm{a}}$ & $1,8^{b}$ & $1,8^{\mathrm{bc}}$ & $2,0^{c}$ & & \\
\hline EPM & 0,06 & 0,07 & 0,08 & 0,07 & & \\
\hline
\end{tabular}

EPM $^{*}$ - Erro padrão da média

Médias na linha seguidas de mesmas letras minúsculas não diferem entre si $(P>0,10)$

Médias na coluna seguidas de mesmas letras maiúsculas não diferem entre si $(P>0,10)$

Observa-se que avaliações realizadas em diferentes datas, mas pertencentes a estações do ano semelhantes, apresentaram valores médios de consumo diário de forragem diferentes para as mesmas alturas de dossel forrageiro estudas. Isso pode ter ocorrido, pois na primeira avaliação realizada em janeiro de 2002, os pastos ainda não se encontravam em equilíbrio ("imaturos"), observando-se a ocorrência de hastes na porção superior dos dosséis forrageiros (Figuras 13 a 18), as quais podem ter contribuído para reduzir a profundidade do estrato potencialmente pastejável, dificultando a apreensão de forragem. Em dezembro de 2002, após 12 meses de equilíbrio das condições de pasto avaliadas, a participação de hastes na porção superior dos dosséis era menor, com maior participação relativa de material morto na base dos pastos comparativamente a janeiro de 2002. Nesse contexto, em janeiro a densidade volumétrica do estrato potencialmente pastejável dos pastos foi maior, o que pode ter contribuído para o menor consumo de forragem. 


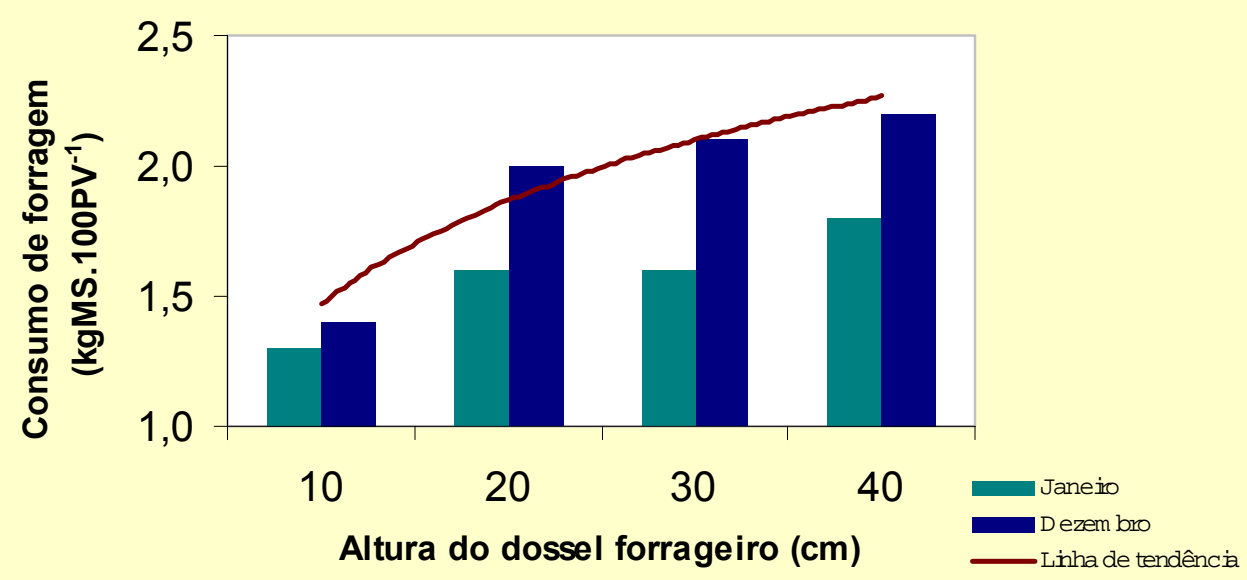

Figura 25 - Consumo de forragem em kg MS.100kgPV ${ }^{-1}$ de animais mantidos em pastos de capim-Marandu submetidos a quatro alturas de dossel forrageiro nos meses de janeiro e dezembro de 2002.

\subsubsection{Consumo de FDN}

Com base nos teores de fibra insolúvel em detergente neutro (FDN) da forragem consumida ${ }^{1}$, que apresentaram variação de 60,7 a 62,9 \% MS nas diferentes alturas de dossel forrageiro e mês do ano avaliado, o consumo diário de FDN foi influenciado pela altura do dossel forrageiro $(P=0,0001)$ e pelo mês do ano ( $P=0,0001$ ) (Tabela 10 e Figura 26$)$. Não houve efeito da interação altura do dossel:mês do ano $(P=0,3897)$. A amplitude dos valores médios de consumo de FDN nos meses avaliados foi de 0,8 (10 cm, janeiro) e 1,3 kg FDN.100kgPV ${ }^{-1}$ (20, 30 e $40 \mathrm{~cm}$, agosto), valores esses muito próximos aos obtidos por Balsalobre (1996) trabalhando com capim Elefante (Pennisetum purpureum Schum.) com teores de FDN entre 63 e $67 \%$ MS, onde os consumos de FDN para vacas em lactação foram entre 1,28 e 1,58 kg FDN.100kgPV-1.

\footnotetext{
1 ANDRADE, F. M. E. (Escola Superior de Agricultura "Luiz de Queiroz", Piracicaba, SP). Valor nutritivo da forragem e desempenho de bovinos de corte em pastos de Brachiaria brizantha cv. Marandu. (projeto de mestrado em andamento).
} 
Esse mesmo autor em 2002, trabalhando com capim Tanzânia (Panicum maximun Jacq.) em regime de lotação intermitente submetido a três níveis de resíduo pós-pastejo, obteve consumos de FDN que variaram de 1,14 a 1,43 kg FDN.100kgPV ${ }^{-1}$. Manzano (2002) trabalhando com capim Tanzânia (Panicum maximun Jacq.) em regime de lotação intermitente submetido a três níveis de resíduo pós-pastejo, observou consumos de FDN que variaram de 1,41 a 1,52 kg FDN.100kgPV ${ }^{-1}$.

Tabela 10. Consumo de FDN kg MS.100kgPV ${ }^{-1}$ de animais mantidos em pastos de capim-Marandu submetidos a quatro alturas de dossel forrageiro nos meses de janeiro e dezembro de 2002.

\begin{tabular}{|c|c|c|c|c|c|c|}
\hline \multirow{2}{*}{ Mês } & \multicolumn{4}{|c|}{ Altura $(\mathrm{cm})$} & \multirow[t]{2}{*}{ Média } & \multirow[t]{2}{*}{ EPM $^{*}$} \\
\hline & 10 & 20 & 30 & 40 & & \\
\hline Janeiro & 0,8 & 1,0 & 1,0 & 1,1 & $1,0^{A}$ & 0,03 \\
\hline Dezembro & 0,9 & 1,3 & 1,3 & 1,3 & $1,2^{\mathrm{B}}$ & 0,03 \\
\hline Média & $0,8^{a}$ & $1,1^{\mathrm{b}}$ & $1,1^{\mathrm{bc}}$ & $1,2^{\mathrm{C}}$ & & \\
\hline EPM & 0,03 & 0,04 & 0,05 & 0,04 & & \\
\hline
\end{tabular}

EPM $^{*}$ - Erro padrão da média

Médias na linha seguidas de mesmas letras minúsculas não diferem entre si $(P>0,10)$

Médias na coluna seguidas de mesmas letras maiúsculas não diferem entre si $(P>0,10)$ 


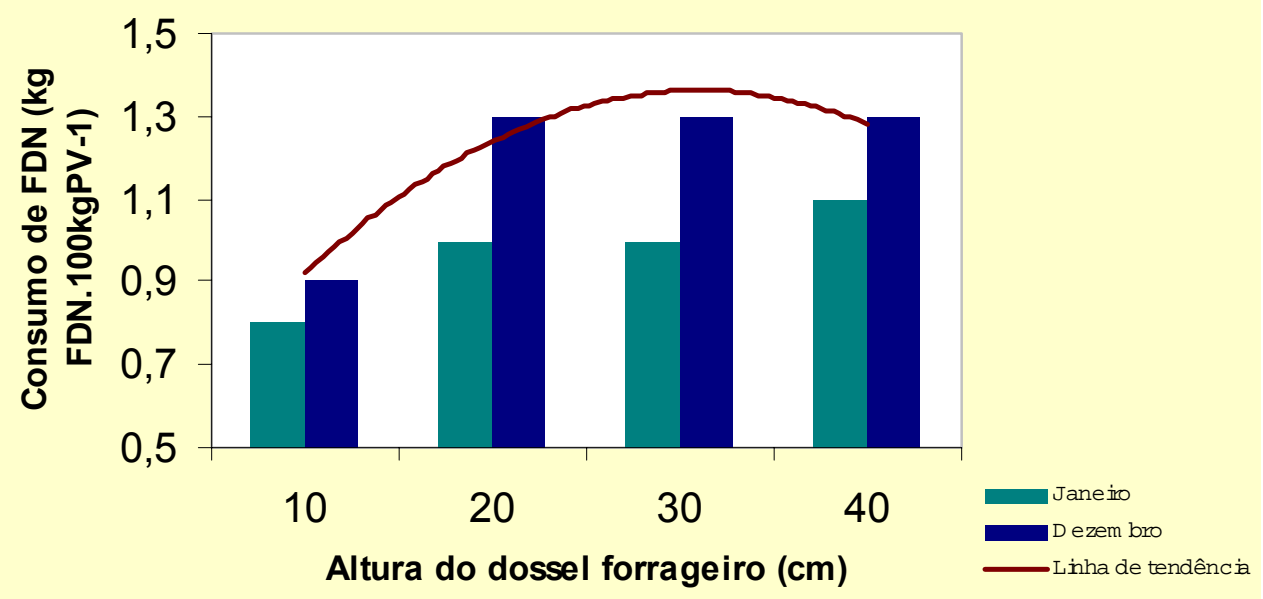

Figura 26 - Consumo de FDN em kg MS. $100 \mathrm{kgPV}^{-1}$ de animais mantidos em pastos de capim-Marandu submetidos a quatro alturas de dossel forrageiro nos meses de janeiro e dezembro de 2002.

Os valores apresentados, assim como os observados por Balsalobre (1996 \& 2002) e Manzano (2002), não corroboram a afirmativa de

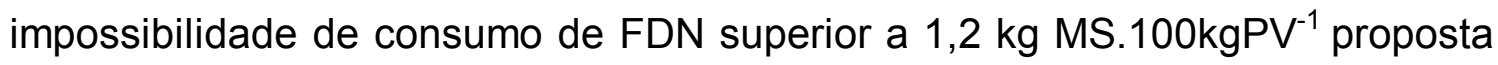
por Mertens (1994), e reforçam a importância da correlação existente entre os componentes da estrutura do dossel forrageiro $e$ as variáveis de comportamento ingestivo na determinação do consumo de animais em pastagens de clima tropical. 


\section{CONCLUSÕES}

O conjunto de dados gerados foi bastante consistente, apesar do número reduzido de avaliações frente ao planejado no início do experimento.

As características estruturais do dossel forrageiro (altura e densidade volumétrica) determinaram os padrões de comportamento ingestivo dos animais.

O consumo diário de forragem apresentou um platô entre as alturas de 20, 30 e $40 \mathrm{~cm}$, sendo que essa amplitude de condições poderia ser utilizada no manejo do pastejo de Brachiaria brizantha cv. Marandu. A escolha de uma determinada altura de pasto seria função do objetivo e da natureza do sistema de produção em questão.

A ingestão de forragem pode ser controlada através de variações em condição e estrutura do dossel forrageiro, situação essa que demonstra o potencial de planejamento e monitoramento de estratégias de pastejo baseadas em metas de condição de dossel para níveis variáveis de exigências nutricionais, épocas do ano e espécie animal. 


\section{REFERÊNCIAS BIBLIOGRÁFICAS}

ANDRADE, R. P. de. Tecnologia de produção de sementes de espécie do gênero Brachiaria. In: SIMPÓSIO SOBRE MANEJO DE PASTAGEM Brachiaria, 11., Piracicaba, 1994. Anais. Piracicaba: FEALQ, 1994, p. 4972.

ALLDEN, W.G; WHITTAKER, McD. The determinants of herbage intake by grazing sheep: the interrelationship of factors influencing herbage intake and availability. Australian Journal of Agricultural Research, v. 21, p. 755766. 1970.

ARIAS,J.E.;DOUGHERTY,C.T.;BRADLEY,N.W.;CORNELIUS,P.L.;LAURIAULT, L.M. Structure of tall fescue swards and intake of grazing cattle. Agronomy Journal, v.82, p.545-548, 1990.

BARTHARAM, G.T. Sward struture and the depth of grazed horizon. Grass and Forage Science, v. 36, p. 130-131, 1981.

BETTERIDGE, K.; FLETCHER, R.H.; LIU, Y.; COSTALL, D.A.; DEVANTIER, B.P. Rate of removal of grass from mixed pastures by cattle, sheep and goat grazing. Proceedings of New Zealand Grassland Association, v. 56, p. 6165, 1994.

BLACK, J.L.; KENNEY, P.A. Factors affecting diet selection by sheep. II. Height and density of pasture. Australian Journal of Agricultural Research, v. 35, p.565-578, 1984.

BURLINSON, A.J. e HODGSON, J. The influence of sward structure on the mechanics of the grazing process in sheep. Animal Production, v. 40, p. 581-582, 1985. 
BURLINSON, A.J.; HODGSON, J.; ILLIUS, A.W. Sward canopy structure and the bite dimensions and bite weight of grazing sheep. Grass and Forage Science, v. 46, p. 29-38, 1991.

BURNS, J. C.; POND, K.R.; FISHER, D.S. Measurement of forage intake. In: FAHEY Jr., G. (Ed.). Forage quality evaluation and utilization. Madison: American Society of Agronomy, 1994. p. 494-532.

BRÂNCIO, P. A.; NASCIMENTO JÚNIOR, D. do; EUCLIDES, V. P. B.; REGAZZI, A. J.; ALMEIDA, R. G de.; FONSECA, D. M. da. Avaliação de três cultivares de Panicum maximum Jacq. sob pastejo: 5 - Tamanho de bocado. In: REUNIÃO ANUAL DA SOCIEDADE BRASILEIRA DE ZOOTECNIA, 37., Viçosa, 2000. Anais. Viçosa: SBZ, 2000.

BRASIL. Ministério da Agricultura. Serviço Nacional de Pesquisa Agronômica. Comissão de Solos. Levantamento de reconhecimento dos solos do estado de São Paulo. Rio de Janeiro, 1960. 634p. (Boletim, 12).

CARVALHO, P.C.F.; PRACHE, S.; DAMACENO, J.C. O Processo de pastejo: Desafios da procura e apreensão da forragem pelo herbívoro. In: JÚNIOR, A.M.P. (Ed.). Mecânica e processo de ingestão de forragem em pastejo., Porto Alegre: SBZ, 1999. p.253-268, 344p.

CARVALHO, P.C.F. A estrutura das pastagens e o comportamento ingestivo de ruminantes em pastejo. In: SIMPÓSIO SOBRE AVALIAÇÃO DE PASTAGENS COM ANIMAIS, 1, Maringá, 1997. p. 25-52.

CHACON, E. A.; STOBBS, T.H. Influence of progressive desfoliation of a grass sward on the eating behaviour of cattle. Australian Journal of Agricultural Research, v.29, p.89-102, 1976.

COLEMAN, S.W. Plant-animal interface. Journal of Production Agriculture, v. 5, p.7-13, 1992.

COSGROVE, G.P. Grazing behaviour and forage intake. In: SIMPÓSIO INTERNACIONAL SOBRE PRODUÇÃO ANIMAL EM PASTEJO. Viçosa, 1997. Anais. Viçosa: UFV, 1997. p. 59 - 80. 
CRONQUIST, A. The evolution and classification of flowering plants. New York: New Tork Botanical Gardens, 1988. 555p.

DA SILVA, S.C.; PEDREIRA, C.G.S. Princípios de ecologia aplicados ao manejo de pastagem. In: SIMPÓSIO SOBRE ECOSSISTEMAS DE PASTAGENS, 3., Jaboticabal, 1997. Anais. Jaboticabal : FUNEP, 1997. p. $1-62$.

DA SILVA, S. C.; SBRISSIA, A. F. A planta forrageira no sistema de produção. In: SIMPÓSIO SOBRE MANEJO DE PASTAGEM, 17, Piracicaba, 2000. A planta forrageira no sistema de produção: Anais. Piracicaba: FEALQ, 2000. p. 3-21.

DEMMENT, M.W. e LACA, E.A. Reductionism and synthesis in grazing sciences: models and experiments. Proceedings Australian Society of Animal Production. P. 1- 18. 1994.

EMPRESA BRASILEIRA DE PESQUISA AGROPECUÁRIA. Sistema brasileiro de classificação de solos. Brasília: EMBRAPA Produção de Informação, 1999. 412p.

EDWARDS, G. R.; PARSONS, A.J.; PENNING, P.D.; NEWMAN, J.A. Relationship between vegetation state and bite dimensions of sheep grazing contrasting plant species and its implications for intake rate and diet selection. Grass and Forage Science, v. 50, p. 378-388, 1995.

ERLINGER, L. L.; TOLLESON, D. R.; BROWN, C. J.; Comparasion of bite size, biting rate and grazing time of beef heifers from herds distinguished by mature size and rate of maturity. Journal of Animal Science, v. 68, p. 3578 -3587, 1990.

FAGUNDES, J. L. Efeitos de intensidades de pastejo sobre o índice área foliar, interceptação luminosa e acúmulo de forragem em pastagens de Cynodon spp. Piracicaba, 1999. 69p. Dissertação (Mestrado) - Escola Superior de Agricultura "Luiz de Queiroz", Universidade de São Paulo. 
FLORES, E.R.; LACA, E.A.; GRIGGS, T.C.; DEMMENT, M.W. Sward height and vertical morphological differentiation determine cattle bite dimensions. Agronomy Journal, v. 85, p. 527-532, 1993.

FORBES, J.M. Voluntary feed intake. In: FORBES, J.M.; FRANCE, J. (Ed.). Quantitative aspects of ruminant digestion and metabolism. Cambridge: University Press, 1993. p.479-494.

GHISI, O.M.A.; PEDREIRA, J.V.S. Características agronômicas das principais Brachiaria spp. In: ENCONTRO SOBRE CAPINS DO GÊNERO Brachiaria, Nova Odessa, 1986. Anais. Nova Odessa: Instituto de Zootecnia, 1987. p. 19-58.

GONÇALVES, A.C. Características morfogênicas e padrões de desfolhação em pastos de capim marandu submetidos a regimes de lotação contínua Piracicaba, 2002. 124p. Dissertação (Mestrado) - Escola Superior de Agricultura "Luiz de Queiroz", Universidade de São Paulo.

GORDON, L.I.; ILLIUS, A.W. Foraging strategy: From monoculture to mosaics. In: SPEEDY, A.W.(Ed.). Progress in sheep and goat research. Wallingford: CAB International, UK. 1992 p.153-178.

GORDON, L.I.; LASCANO, C. Foraging strategies of ruminants livestock on intensively managed grassland: potential and constrains. In: Palmerston North, New Zealand, 1993. p.681-690.

GORDON, L.I.; ILLIUS, A.W.; MILNE, J.D. Sources of variation in the foraging efficiency of grazing ruminants. Functional Ecology, v. 10, p. 219-226.1996. GRANT, S. Resource description: vegetation and sward components. In: DAVIES, R.D. et al. eds. Sward measurement Handbook, 2nd ed., Reading, 1993. p.69-98.

GREENBERG, A.R.; MEHLING, A.; LEE, M.; BOCK, J.H. Tensile behavior of grass. Journal of Materials Science, v. 24, p. 2549-2554, 1989.

HODGSON, J. Variations in the surface characteristics of the sward and shortterm rate of herbage intake by calves and lambs. Grass and Forage Science, v. 36, p. 49-57, 1981. 
HODGSON, J. Ingestive behavior. In: LEAVER, J.D. (Ed.) . Herbage intake handbook. Wallingford: British Grassland Society, 1982. p.113-138.

HODGSON, J. The control of herbage intake in the grazing ruminant. Proceedings of the Nutrition Society, v. 44, p. 339-346. 1985.

HODGSON, J. Grazing management: science into practice. Longman Scientific \& Technical, 1990. 203p.

HODGSON, J. Sward conditions, herbage allowance and animal production: an evaluation of research results. Proceedings of New Zealand Society of Animal Production, v: 44, p. 99-104. 1984.

HODGSON, J.; CLARK, D.A.; MITCHELL, R.J. Foraging behavior in grazing animals and its impact on plant comunities. In: NATIONAL CONFERENCE Forage quality, evaluation and utilization. National Conference on Forage Quality, Lincon: American Society of Agronomy, 1994. p. 796-827.

HODGSON, J.; BIRCHAM, J. S.; GRANT, S. A.; KING, J. The influence of cutting and grazing management on herbage growth and utilization. In: PLANT PHYSIOLOGY AND HERBAGE PRODUCTION, OCCASIONAL SYMPOSIUM, 13., Belfast, 1981. Proccedings. Belfast: British Grassland Society, 1981, p. 51-62.

HUGHES, T.P.; GALLAGHER, J.R. Influence of sward height on the mechanics of grazing and intake rate by racehorses. In: of the International Grassland Congress, 17, Palmerston North, Proceedings, 1993. p. 1325-1326.

KRYSL, I. J.; HESS, B.W. Influence of suplementation on behavior of grazing cattle. Journal of Animal Science, v. 71, p. 2546-2555, 1993.

ILLIUS, A.W.; GORDON, I.J. The allometry of food intake in grazing ruminants. Journal of Animal Ecology, v. 56, p. 989-999, 1987.

ILLIUS, A. W. Costs and benefits of foraging on grasses varying in canopy structure and resistence to defoliation. Functional Ecology, v.9, p.894-903, 1995. 
LACA, E.A.; DEMMENT, M.W. Modelling intake of a grazing ruminant in a heterogeneous environment. In: INTERNATIONAL SYMPOSIUM ON VEGETATION: HERBIVORE RELATIONSHIPS, New York, 1992. p.57-76.

LACA, E.A.; UNGAR, E.D.; SELIGMAN, N.G.; DEMMENT, M.W. Effects of sward height and bulk density on bite dimensions of cattle grazing homogeneous swards. Grass and Forage Science, v. 47, p. 91-102. 1992b.

LACA, E.A.; DEMMENT, M.W.; DISTEL, R.A.; GRIGGS, T.C. A conceptual model to explain variation in ingestive behavior within a feeding patch. In: INTERNATIONAL GRASSLAND CONGRESS, 17, Palmerston North, New Zealand. Proceedings, p.710-712, 1993.

LACA, E.A.; UNGAR, E.D.; DEMMENT, M.W. Mechanisms of handling time and intake rate of a large mammalian grazer. Applied Animal Behavior Science, v.39, p. 3-19. 1994.

LACA, E.A.; LEMAIRE, G. Measuring sward structure. In: MANNETJE, L., JONES, R.M. (ed.) . Field and laboratory methods for grassland and animal production research. Wallingford: CABI Publ., 2000. p.103-121.

LEAFE, E. L.; PARSONS, A. J. Physiology of growth of grazed sward. In: INTERNATIONAL GRASSLAND CONGRESS, 14., Lexington, Kentucky, 1981. Proceedings. Boulder: Westview Press, 1983. p. 403-406.

LEMAIRE, G. The physiology of grass growth under grazing: tissue turnover. In:SIMPÓSIO INTERNACIONAL SOBRE PRODUÇÃO ANIMAL EM PASTEJO, 1997.Viçosa. Anais: Viçosa: UFV, 1997. p.117-144

L'HUILLIER,P.J.; POPPI,D.P.; FRASER,T.J. Influence of structure and composition of ryegrass and prairie grass-white clover swards on the grazed horizon and diet harvested by sheep. Grass and Forage Science, v.41, p.259-267, 1986.

MACEDO, M.C.M. Pastagens no ecossistema Cerrados: pesquisa para o desenvolvimento sustentável. In: SIMPÓSIO SOBRE PASTAGENS NOS ECOSSISTEMAS BRASILEIROS, Brasília, 1995. Anais. Brasília: SBZ, 1995. p.28-62. 
McMEEKAN, C.P. Grazing management and animal production. In:INTERNATIONAL GRASSLAND CONGRESS 7, Palmerston North, 1956.Proceedings. P.146-156.

McNAIR; BONNELLI. Basis chromatography. 4 ed. Palo Alto: Varian Instrument Division Offices, 1968. p. 137-167.

MERTENS, D.R. ANÁLISE DA FIBRA E SUA UTILIZAÇÃO NA AVALIAÇÃO E FORMULAÇÃO DE RAÇÕES. In: SIMPÓSIO INTERNACIONAL DE RUMINANTES, Reunião da Sociedade Brasileira de Zootecnia, 29. Lavras, 1992. Anais. Lavras: SBZ., 1992. p.188-219.

MERTENS, D.R. Regulation of forage intake. In: FAHEY, G.C.Jr.; COLLINS, M.; MERTENS, D.R.; MOSER, L.E. (Ed.). Forage quality evaluation and utilization. Madison: American Society of Agronomy, Crop Science of America; Soil Science of America, 1994. 988 p.

MITCHELL, R. J.; HODGSON, J.; CLARK, D.A. The effect of varying leafy sward height and bulk density on the ingestive behavior of young deer and sheep. Proceedings of the New Zealand Society of Animal Production, v. 51 , p. $159-165.1991$.

MITIDIERI, J. Manual de gramíneas e leguminosas para pastos tropicais. São Paulo: Nobel, 1983. 198p.

MORRONE, O.; ZULOAGA, F.O. Revision de las especies sudamericanas nativas e introducidas de los generos Brachiaria y Urochloa (Poaceae: Panicoideae: Paniceae). Darwiniana, v. 31, p.43-109p, 1992.

MURSAN, A.; HUGHES, T.P.; NICOL, A.M.; SUGIURA, T. The influence of sward height on the mechanics of grazing in steers and bulls. Proceedings of the New Zealand Society of Animal Production, v.49, p. 233-236, 1989.

NEWMAN, J.A.; PARSONS, A.J.; PENNING, P.D. A note on the behavioural strategies used by grazing animals to alter their intake rates. Grass and Forage Science, v. 49, p. 502-505. 1994b. 
NOLLER, C.H.; NASCIMENTO JÚNIOR, D.; QUEIROZ, D. S. Exigências nutricionais de animais em pastejo. In: SIMPÓSIO SOBRE MANEJO DE PASTAGEM, 13, Piracicaba, 1996. Anais: Piracicaba: FEALQ, 1996. p. 319352.

NUNES, S.G.; BOOCK, A.; PENTEADO, M.I. de O.; GOMES, D.T. Brachiaria brizantha cv. Marandu. 2.ed. Campo Grande, EMBRAPA, CNPGC, 1985. 31p. (EMBRAPA, CNPGC. Documentos, 21).

NUSSIO, L.G.; MANZANO, R.P.; PEDREIRA, C.G.S. Valor alimentício em plantas do gênero Cynodon. In: SIMPÓSIO SOBRE MANEJO DE PASTAGEM. Manejo de pastagens de Tífton, Coastcross e Estrela. 1998. Piracicaba. Anais... Piracicaba: FEALQ. 1998, p.203-242.

OMETO, J.C. Registros e estimativas dos parâmetros meteorológicos da região de Piracicaba, SP. Piracicaba: FEALQ, 1989. 76p.

O'REAGAIN, P.J.; MENTIS, M.T. The effect of plant structure on the acceptability of different grass species to cattle. Journal of Grassland Society of South Africa, v.6, p.163-170, 1989.

PARSONS, A.J.; THORNLEY, H.M.; NEWMAN, J.; PENNING, P.D. A mechanistic model of some physical determinants of intake rate and diet selection in a two-species temperate grassland sward. Funcional Ecology, v. 8, p. $187-204,1994$.

PENNING, P.D. Some effects of sward conditions on grazing behavior and intake by sheep. In: NATO ADVANCED RESEARCH WORKSHOP, Hvanneyri, Iceland. 1986. p. 219-226.

PENNING, P.D.; ROOK, A.J.; ORR, R.J. Patterns of ingestive behavior of sheep continuosly stocked on monocultures of rygrass or white clover. Applied Animal Behavior Science, v. 31, p. 237-250, 1991a.

PENNING, P.D.; ROOK, A.J.; ORR, R.J.; TREACHER, T.T. Intake and behavior responses by sheep to changes in sward characteristics under continuous stocking. Grass and Forage Science, v. 46, p. 15-28, $1991 \mathrm{~b}$. 
POPPI, D.P.; HUGHES, T.P.; I'HUILLIER, P.J. Intake of pasture by grazing ruminants. In: NICOL, A.M. (Ed.). Livestock feeding on pasture. Hamilton: New Zealand Society of Animal Production, 1987, p.55-64. (Occasional Publication, 10).

PRACHE, S. Intake rate, intake per bite and time per bite of lactating ewes on vegetative and reproductive swards. Applied Animal Behavior Science, v.52, p.53-64, 1997.

PRACHE, S., PEYRAUD, J. Préhensibilité de l'herbe pâturée chez les bovins et les ovins. INRA Productions Animales, v.10, p.377-390.1997.

RAIJ, B. van; CANTARELLA, H.; QUAGGIO, J.A.; FURLANI, A.M.C. (Ed.) Recomendações de adubação e calagem para o Estado de São Paulo. 2. ed. Campinas: Instituto Agronômico \& Fundação IAC, 1996. 258p. (Boletim Técnico, 100).

RENVOIZE, S.A.; CLAYTON, W.D.; KABUYE, C.H.S. Morphology, taxonomy and natural distribution of Brachiaria (Trin.) Griseb.. In: MILES, J.W.; MASS, B.L.; VALLE, C.B. (Ed.) Brachiaria: biology, agronomy and improvement. Cali: CIAT; Campo Grande: EMBRAPA CNPGC, 1996. cap.1, p.1-15.

SAS INSTITUTE. http://sasdocs.ucdavis.edu. (10 abril 2003)

SANTOS FILHO, L.F. Seed production: perspective from the Brazilian private sector. In: MILES, J.W.; MASS, B.L.; VALLE, C.B. (Ed.) Brachiaria: biology, agronomy and improvement. Cali: CIAT; Campo Grande: EMBRAPA CNPGC, 1996, cap.9, p.141-146.

SBRISSIA, A. F.; DA SILVA, S. C. O ecossistema de pastagens e a produção animal. In: MATTOS, W. R. S. (Ed.). A produção animal na visão dos brasileiros, Piracicaba: SBZ, 2001. p.731-754.

SHIPLEY, L.A.; SPALINGER, D.E.; GROSS, J.E.; HOBBS, N.T.; WUNDER, B.A. The dynamics and scaling of foraging velocity and encounter rate in mammalian herbivores. Functional Ecology, v. 10, p. 234-244. 1996. 
SPALINGER, D.E.; HOBBS, N.T. Mechanisms of foraging in mammalian herbivores: new models of functional response. American Naturalist, v. 140, n. 2, p. 325-348. 1992.

STOBBS, T.H. The effect of plant structure on the intake of tropical pastures. I.Variation in the bite size of grazing cattle. Australian Journal Agricultural Reseach, v.24, n.6, p.809-819, 1973a.

STOBBS, T.H. The effect of plant structure on the intake of tropical pastures. II.Differences in sward structure, nutritive value, and bite size of animals grazing Setaria anceps and Chloris gayana at various stages of growth. Australian Journal Agricultural Reseach, v.24, n.6, p.821-829, 1973b.

SKERMAN, P. J.; RIVEROS, F. Gramíneas tropicales. Roma: FAO, 1992. 832p. (Colección FAO: Producción y Protección Vegetal, 23).

SOARES FILHO, C. V. Recomendações de espécies e variedades de Brachiaria para diferentes condições In: SIMPÓSIO SOBRE MANEJO DE PASTAGEM

- BRACHIARIA, 11., Piracicaba, SP, 1994. Anais. Piracicaba: FEALQ, 1994, p. 25-49.

UNGAR, E.D.; Ingestive behavior. In: HODGSON, J. e ILLIUS, A.W. (Eds.). The Ecology and Management of Grazing Systems. CAB International, Wallingford, UK. 1996. p. 185-218.

UNTZ, G.; TRANCHANT, J. Manual paratique de chromatographie en phase gazeuse. 3. ed. Paris, Masson. 1982. p. 61-72.

VAN SOEST, P.J. Nutritional ecology of the ruminant. Ithaca: cornell University Press, 1994, 476 p.

WADE, M.H. Factors affecting the availability of vegetative Lolium perenne to grazlng dairy cows with special reference to sward characteristics, stocking rate and grazing method. Thesis of Rennes University. 1991. 70p.

WEBSTER, R. D. Genera of the North American Paniceae (Poaceae: Panicoideae). Systematic Botany. v.13, p. 576-609,1988. 
WHALLEY, R.D.B.; HARDY, M.B. Measuring botanical composition of grassland. In: 't MANNETJE and R.M JONES. Field and laboratory metholds for grassland and animal prodution research. Wallingford: $C A B$ International, , UK. 2000. 64-102 p.

WRIGHT, W.; ILLIUS, A.W. A comparative study of the fracture properties of five grasses. Functional Ecology, v.9, p.269-278, 1995. 